


\title{
Role of palmitoylation in the serotonin receptor functioning
}

\author{
PhD Thesis
}

in partial fulfilment of the requirements

for the degree "Doctor of Philosophy (PhD)/Dr. rer. nat."

in the Neuroscience Program

at the Georg August University Göttingen,

Faculty of Biology

submitted by

Konstantin Glebov

born in

Tyumen,

Russia Federation 
This thesis has been written independently and with no other sources and aids than quoted

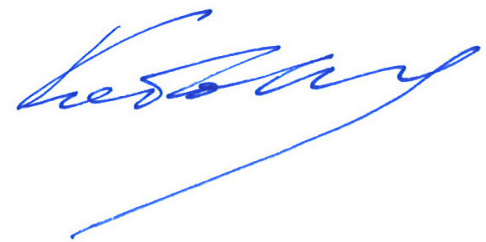

Konstantin Glebov $19^{\text {th }}$ of March 2007 
“...die Eule der Minerva beginnt erst mit der einbrechenden Dämmerung ihren Flug..."

Grundlinien der Philosophie des Rechts Georg Wilhelm Friedrich Hegel Juni 1822 
Dedicated to my parents, grandmother and all my teachers... 


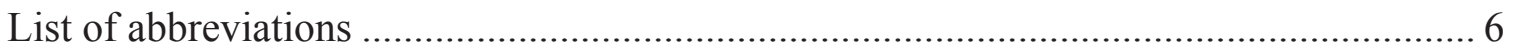

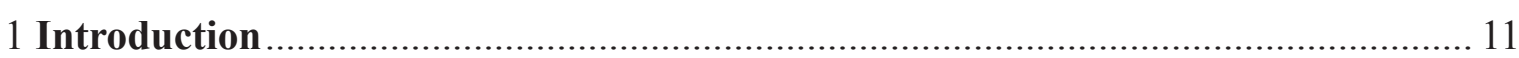

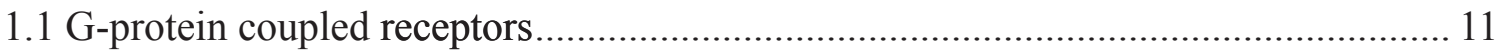

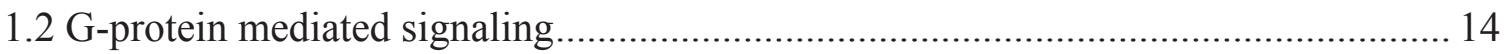

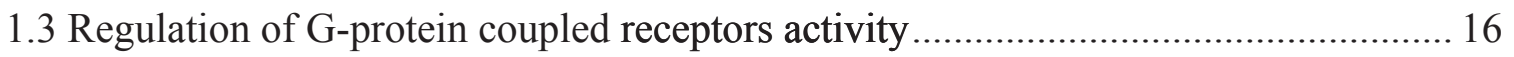

1.3.1 $\beta$-arrestin mediated desensitization as the key regulatory mechanism .................. 16

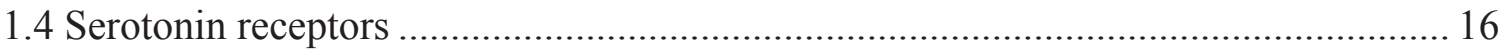

1.5 Posttranslational modifications of G-protein coupled receptors ............................... 20

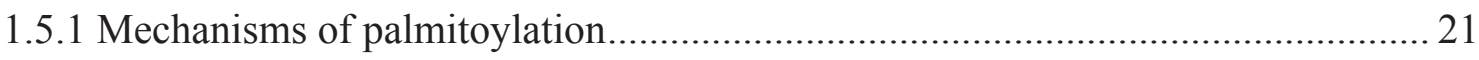

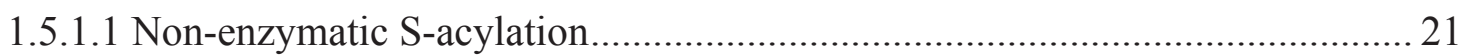

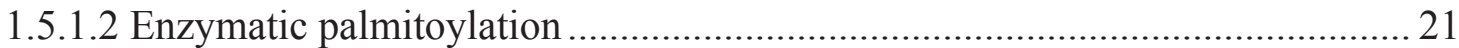

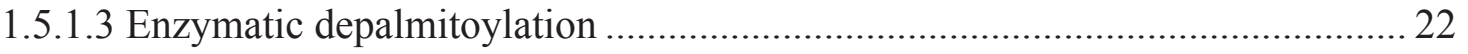

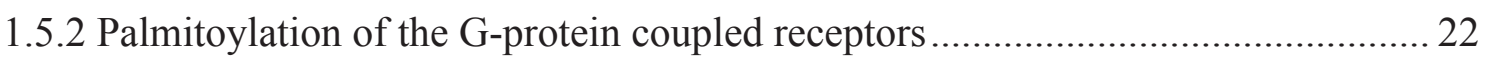

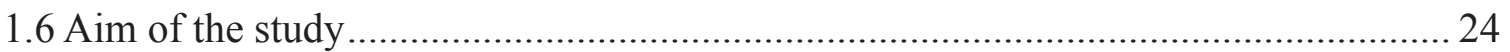

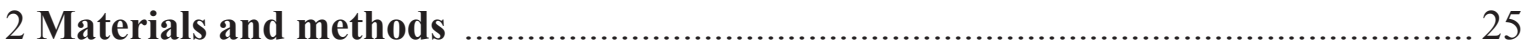

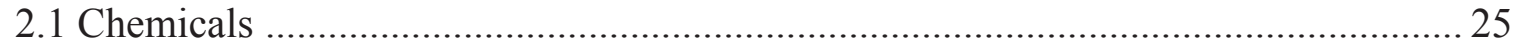

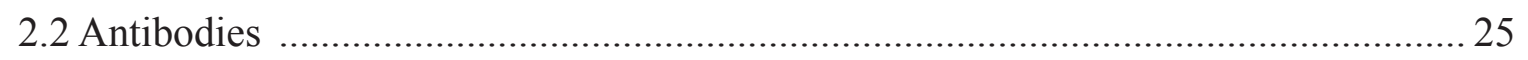

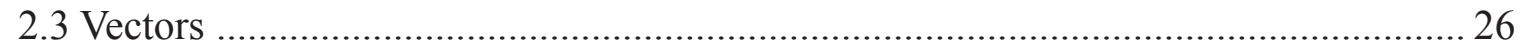

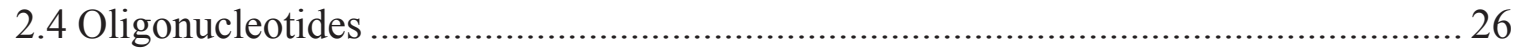

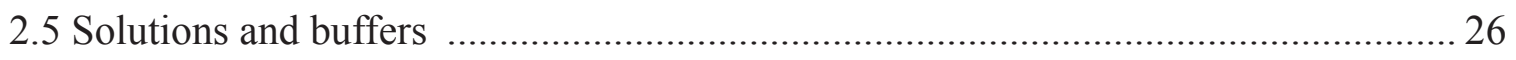

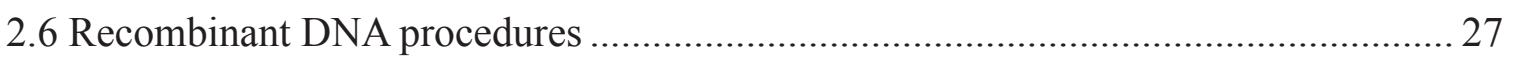

2.6.1 Construction of $5-\mathrm{HT}_{4(\mathrm{a})}$-Rluc fusion protein ................................................. 27

2.6.2 Agarose gel electrophoresis and fragment purification ....................................... 27

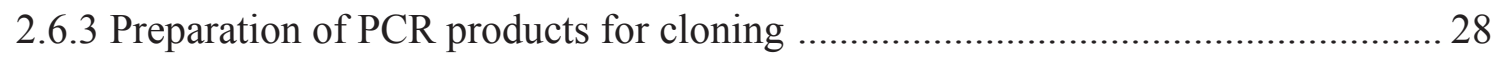

2.6.4 Preparation of expression vectors for cloning .................................................... 28

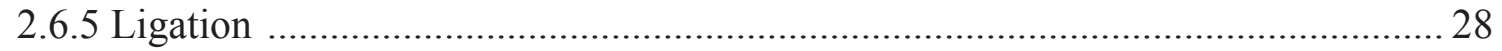

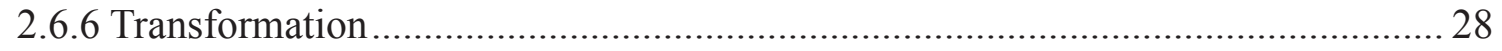

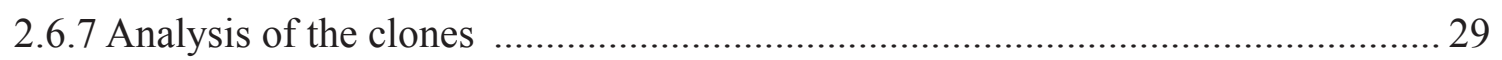

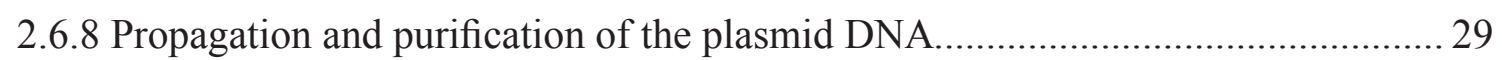

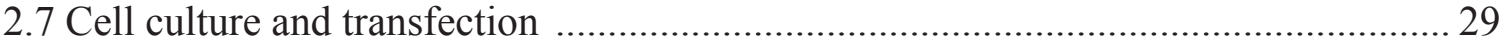

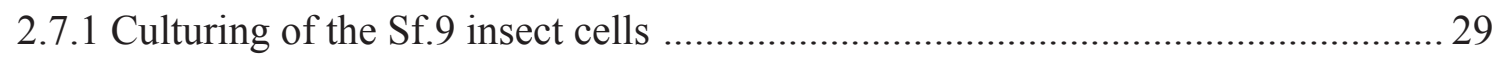

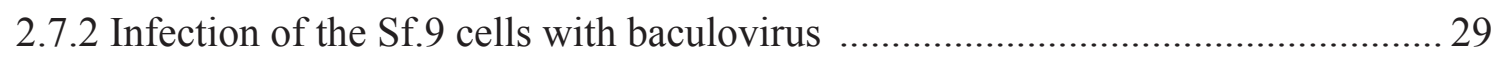

2.7.3 Culturing of the mammalian cells ..................................................................... 30

2.7.4 Transient transfection of the mammalian cells .................................................... 30

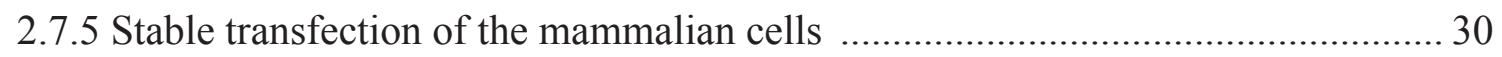

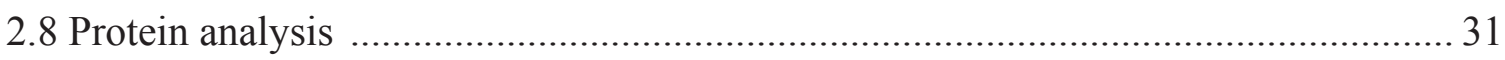

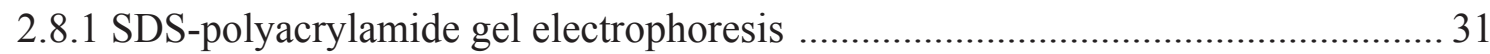

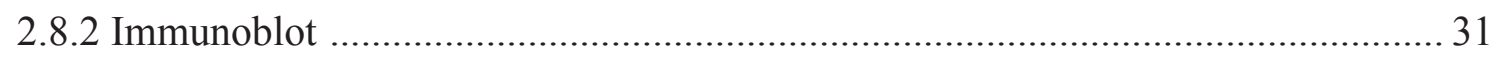




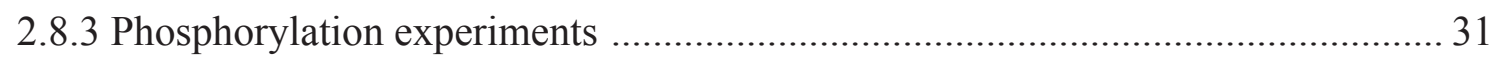

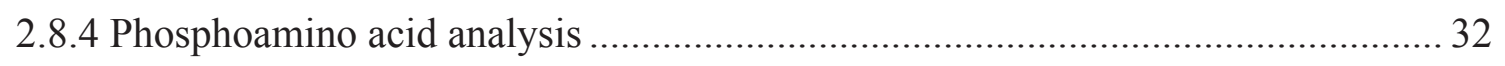

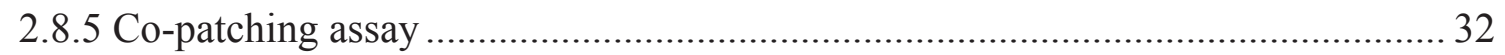

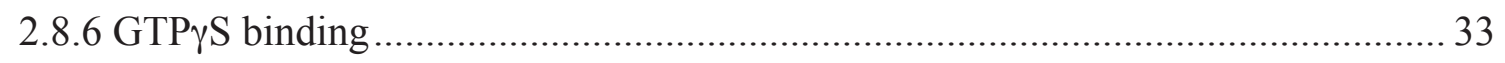

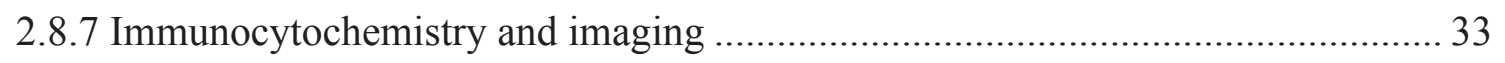

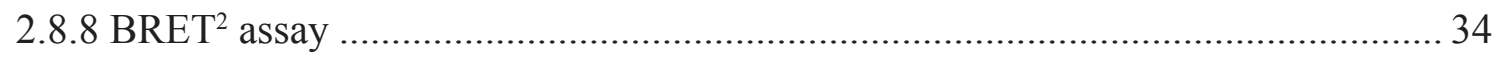

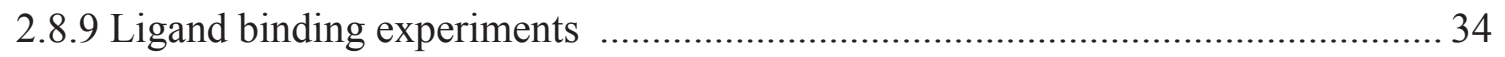

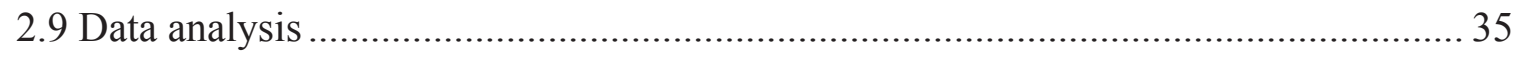

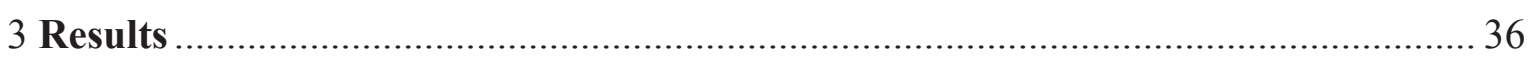

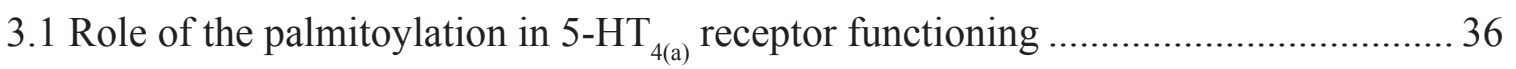

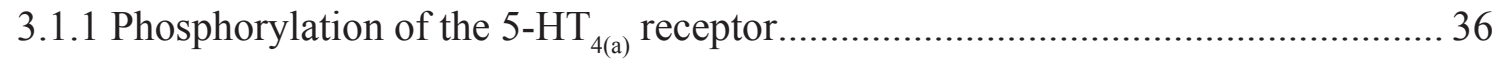

3.1.2 Phosphorylation of palmitoylation-deficient 5- $\mathrm{HT}_{4(\mathrm{a})}$ receptor mutants ................ 36

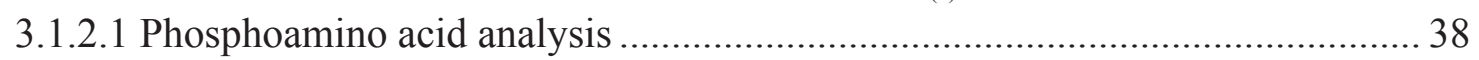

3.1.3 $\beta$-arrestin2 mediated desensitization and internalization of the 5- $\mathrm{HT}_{4(\mathrm{a})}$ receptor 39

3.1.3.1 Role of G-protein receptor kinase in desensitization of the 5- $\mathrm{HT}_{4(\mathrm{a})}$ receptor . 40

3.1.3.2 Role of palmitoylation in agonist-induced internalization

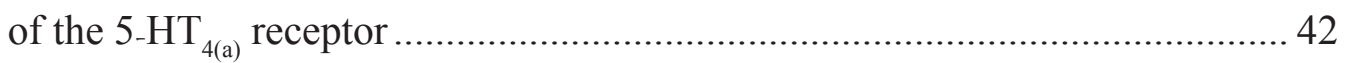

3.1.3.3 BRET $^{2}$ analysis of $\beta$-arrestin2 mediated desensitization of 5-HT $\mathrm{H}_{4(\mathrm{a})}$ receptor .. 44

3.1.3.3.1 Generation, expression and functional properties

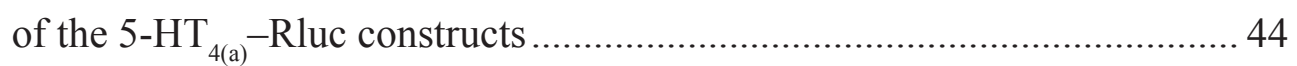

3.1.3.3.2 Pharmacological properties of 5-HT $\mathrm{H}_{4(\mathrm{a})}$ - $\mathrm{Rluc}$ constructs ............................. 45

3.1.3.3.3 Analysis of receptor expression level by using

Renilla luciferase construct luminescence................................................ 45

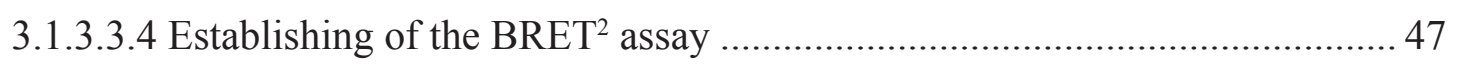

3.1.3.3.5 Dose dependence of receptor- $\beta$-arrestin2 interaction by BRET $^{2}$ assay $\ldots . . .44$

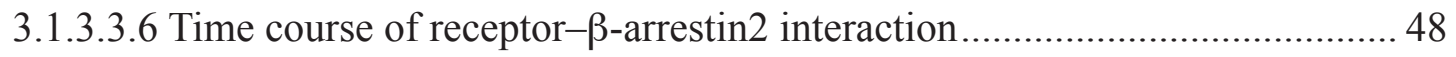

3.1.3.3.7 Role of G-protein receptor kinase in receptor- $\beta$-arrestin2 interaction ........ 51

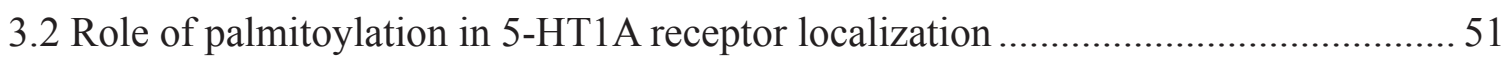

3.2.1 Generation and functional properties of 5-HT1A-YFP fusion constructs .............51

3.2.2 Distribution of wild-type and palmitoylation-deficient

5-HT1A receptors within membrane subdomains ................................................... 54

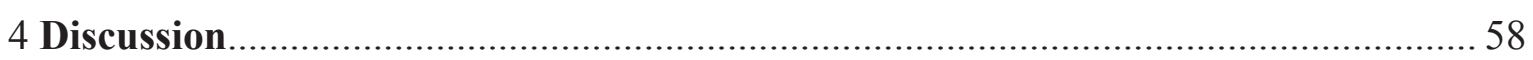

4.1 Role of palmitoylation on $5-\mathrm{HT}_{4(\mathrm{a})}$ receptor functioning ….....................................5 58

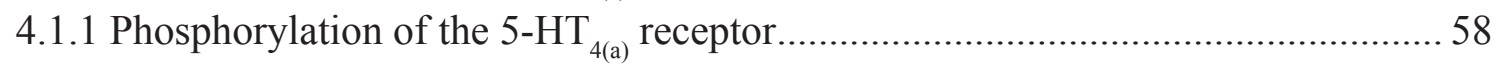

4.1.2 Interaction between palmitoylation and phosphorylation.................................... 58

4.1.3 Role of palmitoylation in $\beta$-arrestin2-mediated

desensitization and internalization of the $5-\mathrm{HT}_{4(\mathrm{a})}$ receptor.................................6 60

4.1.4 Role of palmitoylation in short-term interaction between 
$5-\mathrm{HT}_{4(\mathrm{a})}, \beta$-arrestin2 and G-protein receptor kinase 2; $\mathrm{BRET}^{2}$ analysis ............... 61

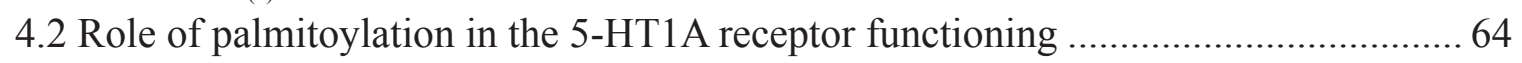

4.2.1 Palmitoylation and localization of the 5-HT1A receptor

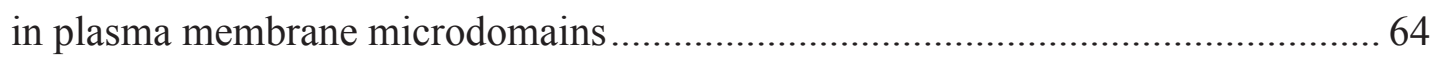

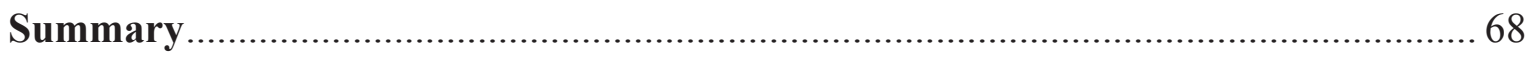

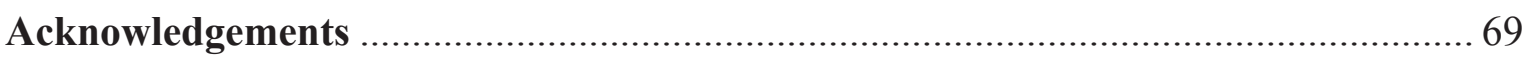

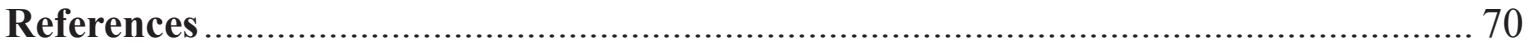

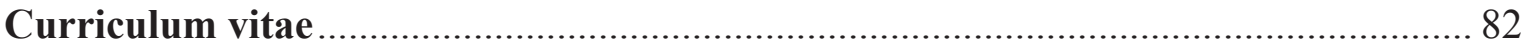


5-HT 5-hydroxytryptamine, serotonin

8-OH-DPAT 8-hydroxy-(di-N-propylamino)-tetralin

$\mathrm{AC}$

adenylate cyclases

AP-2

adaptor protein 2

AR

adrenergic receptor

cAMP

cyclic AMP

CMV

cytomegalovirus

DMEM

Dulbeco modified medium

DTT

dithiothreitol

ER

endoplasmic reticulum, Golgi complex

Erk

extracellular signal regulated kinase

$\mathrm{EtBr}$

ethidium bromide

FCS

fetal calf serum

FSH

follicle stimulatory hormone

GABA

$\gamma$-amino butyric acid

GDI

GDP-dissociation inhibitor

GDP

guanosine 5'-diphosphate

GFP

green fluorescent protein

GIRK

G-protein-activated inwardly rectifying potassium channels

GPCRs

G-protein coupled receptors

GPI

glycophosphatidylinositol

G-protein

GTP binding protein

GRK

G-protein receptor kinase

GTP

guanosine 5'-triphosphate

GTPase

enzyme, which converts GTP to GDP

GTP $\gamma \mathrm{S}$

IP

guanosine 5'-triphosphate, where y-phosphate replaced by the sulfate

inositoltriphosphate

IPTG

isopropyl- $\beta$-D-thiogalactopyranoside

MAPK

mitogen-activated protein kinase

MCS

multicloning site

MMSDH

methylmalonate semialdehyde dehydrogenase

PAGE

polyacrylamide gel electrophoresis

PAT

palmitoylacyltransferase

PCR

polymerase chain reaction

$\mathrm{Pfu} \quad$ plaque forming unit

PLC

phospholipase $\mathrm{C}$

$\operatorname{PLC} \beta$

phospholipase $\mathrm{C} \beta$

PS

penicillin/streptomycin aqueous solution 
Rac

RGS

Rho

SDS

Sf.9

Src

TEMED

TMD

TSH

TX-100

$\mathrm{Wt}$

X-gal

YFP small GTP-binding protein involved in regulating actin cytoskeleton regulator of G-protein signaling

small GTPase, which controls a wide variety of signal transduction pathways

sodiumdodecylsulfate

Spodoptera frugiperda insect cell

non-receptor protein tyrosine kinases transduce signals that control normal cellular processes such as cell proliferation, adhesion tetraeminethylendiamine

transmembrane domain

thyroid stimulatory hormone

Triton X-100

wild-type

5-bromo-4-chlor-3-indolyl- $\beta$-D-galactopyranoside

yellow fluorescent protein 


\section{Introduction}

Almost all internal and external responses of the organism are mediated by the receptor activity. Receptors are necessary for detection and transduction of signals not only inside the organism, but also for communication between living beings. It is rather easy to sustain these functions in single cell organisms or in simple Metazoa, but it is extremely difficult task to maintain all these signal flows in multicellular organisms such as mammals, because all cells and the organs itself should act as a well conducted orchestra. To support such a sophisticated task, nature has created a wide variety of the receptors, which generally can be classified in five distinct classes (Bockaert and Pin 1999). The first class combines receptors which are responsible for the communication between cells. Cytokine receptors are typical members of this group. The second class controls interactions between the cells and the extracellular matrix (e.g. integrine receptors). Tyrosine kinase receptor used as receptors for growth factors are collected in the third class. Ligand-gated ion channels, which are in the class four, are used for transmitting the ions across the plasma membrane. They relay different signals by changing the permeability of the membrane. However, the most common class of the receptors is G-protein coupled receptors (GPCRs). This group mediates a wide variety of signals via interaction of the receptor and guanine nucleotide-binding regulatory proteins termed G-proteins. The G-proteins in turn activate diverse second messengers.

\subsection{G-protein coupled receptors}

G-protein coupled receptors represent a superfamily of receptors with hundreds of affiliates (Bockaert and Pin 1999). GPCRs are perfectly designed for recognition of many internal messenger molecules (such as hormones, neurotransmitters, growth factors and many others), and a number of external signals such as light, odors and gustative molecules by regulating the activity of the G-proteins. All members of the GPCR family have a common feature; they consist of seven transmembrane domains, 3 extracellular and 3 intracellular loops, $\mathrm{N}$ - and C-ends (Figure 1.1). In invertebrates, more than 1 percent of the genome is responsible for coding of the GPCRs. This comprises 2000 receptors, including more than a thousand receptors for odorants and pheromone receptors. For example Caenorhabditis elegance, its genome encodes roughly one thousand and hundred receptors (5\% of the genome) (Bargmann 1998). GPCRs represent the oldest tools regulating signal transduction in plants (Plakidou-Dymock et al. 1998), yeasts (Dohlman et al. 1991) and mold Dictyostelium discoideum (Devreotes 1994). In vertebrates, GPCRs plays also a very important role in organism functioning, beside this GPCRs serve as pharmacological targets to treat some pathophysiological conditions (Angers et al. 2001, Bockaert and Pin 1999, McCudden et al. 2005, Thompson et al. 2005, Vassilatis et al. 2003). Based on differences in sequence, GPCRs are divided into four distinct sub-classes: A, B, C and F/S (Horn et al. 1998). The diversity and versatility of the GPCRs are illustrated in the Figure 1.2. 


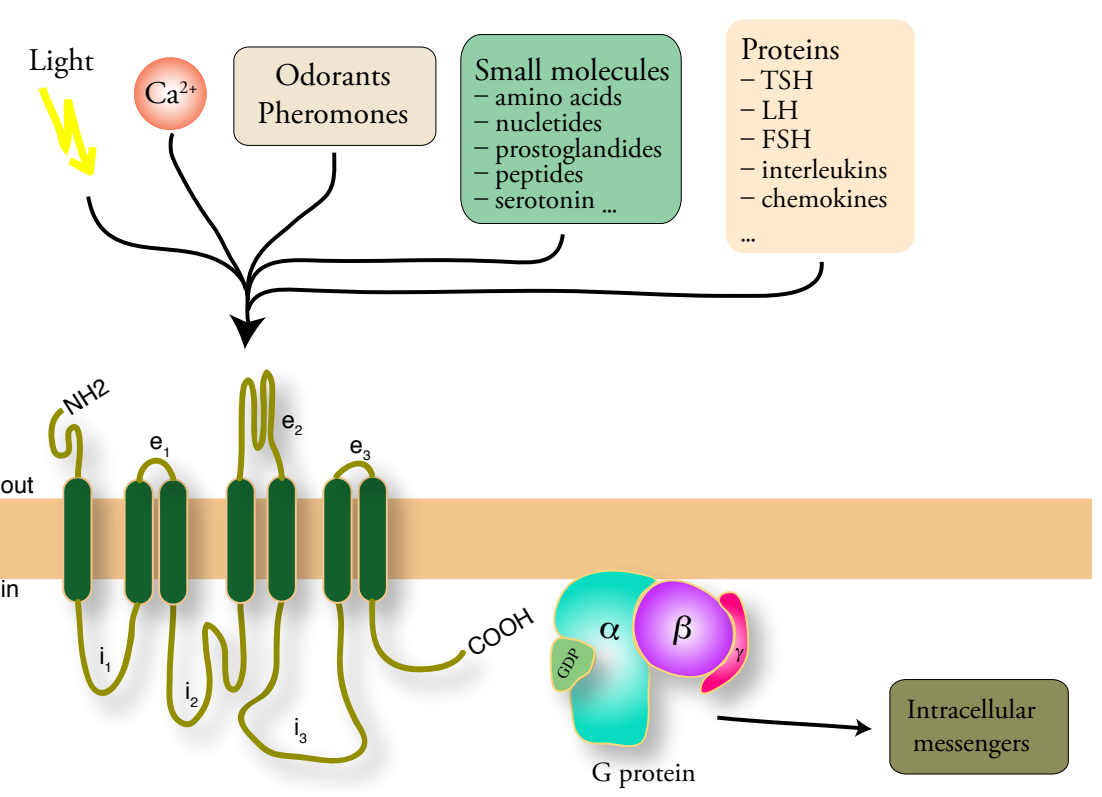

Figure 1.1 The GPCRs are the largest protein family known. Which members are involved in all types of stimulus response pathways, from intercellular communication to physiological senses. The diversity of functions is matched by the wide range of ligands recognized by GPCRs, from photons (rhodopsin) and small molecules (in the case of the histamine receptors) to proteins (for example, chemokine receptors). $\mathrm{e}_{1-3}-$ extacellular loops; $\mathrm{i}_{1-3}-$ intracellular loops

Family A (rhodopsin like receptors) represents the largest GPCRs family. Nevertheless, it can be subdivided into three subfamilies: 1, 2 and 3 by sequence analysis and type of stimulus. Group 1 contains receptors for small ligands like catecholamines or light. In case of catecholamines, ligand binding occurs in a space formed by TMD III and TMD VI. Rhodopsin, which is target of photons, is covalently linked in this space and its conformational changes activate the G-protein. Receptors that belong to the group 2 are usually activated by small peptides, which interact with $\mathrm{N}$-terminal and exctracellular loops (glucagon and secretin receptors) (Bockaert and Pin 1999). Group three is characterized by a huge exctracellular domain, which is responsible for binding of glycoprotein hormones (receptors for TSH and FSH) (Bockaert and Pin 1999). All receptors from family A possess some common features; all of them have highly conserved key residues involved in the formation of a disulfide bridge, which connects the second $\left(\mathrm{e}_{2}\right)$ and third $\left(\mathrm{e}_{3}\right)$ extracellular loop. In addition, most of the members have a palmitoylated cysteine in the $\mathrm{C}$-terminal domain causing the formation of a putative fourth intracellular loop (Figure 1.2) (Gether 2000).

Family B contains receptors, which are activated by large proteins such as parathyroid hormone, pituitary adenylate cyclase-activating polypeptide (PACAP) and secretin. The relatively large (100 amino acids) N-terminal domain also plays a role in ligand binding similar to the receptors from Family A. It also contains several cysteine residues, which may form a network of disulfide bridges (Figure 1.2) (Gether 2000). 


\section{Family A}

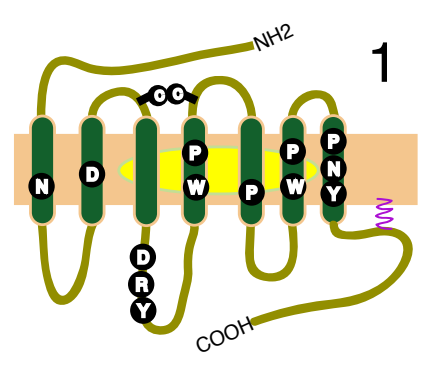

Retinal, Odorants, Catecholamines, Adenosine, ATP, Opiates, Serotonin, Enkephalins

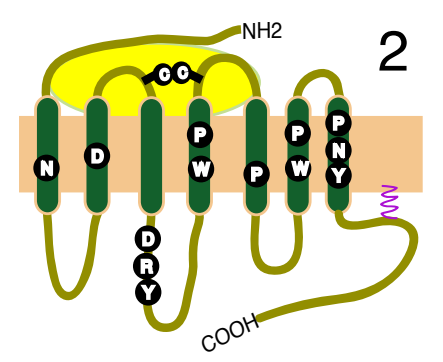

Peptides, Cytokines, fMLP-peptide, PAF-acether, Thrombin

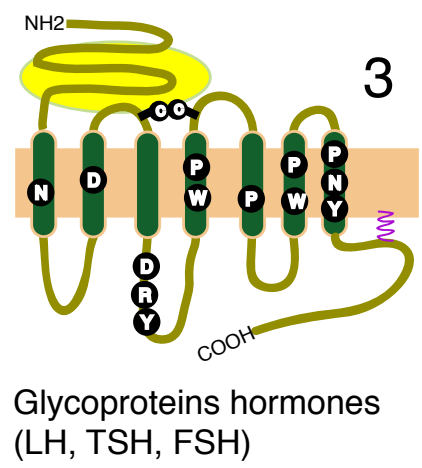

Glycoproteins hormones (LH, TSH, FSH)

\section{Family B}

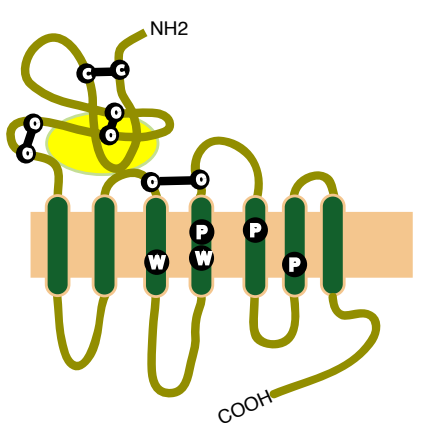

Calcitonin, Secretin, PTH, VIP, CRF

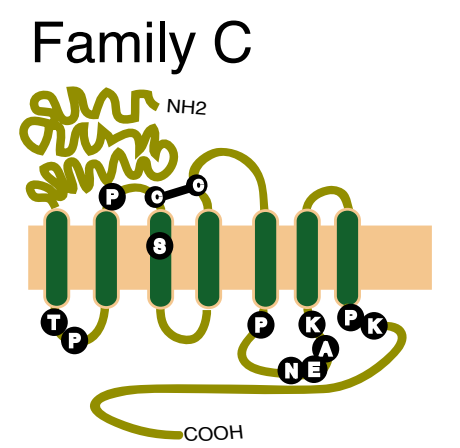

Glutamate, GABA, Pheromones

Figure 1.2 GPCR superfamily can be devided into 3 main subfamilies (corresponding ligands are shown below of the receptor, $\mathbf{D}$ - characteristic amino acids are shown with the single-letter code, $\xi$-palmiylation, - ligand binding area ). Family A contains most of the receptors, including receptors for odorants, small ligands, such as serotonin, catecholamines, opiates and glycoproteins hormones. Receptors from the Family B are activated by a large proteins, such as parathyroid hormone, calcitonin etc. Members of the Family C interact with glutamate, GABA and are also responsible for taste and pheromones recognition.

Family $\mathbf{C}$ receptors include the metabotropic glutamate, $\mathrm{GABA}_{\mathrm{B}}$, calcium receptors, taste and pheromone receptors. The ligand-binding site of these receptors is located within the large extracellular N domain (Figure 1.2) (Gether 2000).

A growing number of researchers reports that the GPCRs can act not only as monomers, but also as functional oligomers (Fotiadis et al. 2006, Herrick-Davis et al. 2004, Nakata et al. 2005). Interestingly, the presence of agonist has been shown to stabilize the dimers of several receptors including $\beta 2$-adrenergic receptor (Hebert et al. 1996) and chemo- 
kine receptor CCR2b (Rodriguez-Frade et al. 1999). This suggests that oligomerisation may play a role either directly in the receptor activation or in subsequent receptor agonist-dependent internalisation and desensitization. Homooligomers and heterooligomers may have a different pharmacological properties and altered internalisation kinetics (Hanyaloglu et al. 2002).

The impact of GPCRs on a pathological state of the organism has been well documented. GPCRs are involved in a wide range of disorders such as allergies, depression, cancer, obesity, pain, diabetes and many others (Lundstrom 2005, Tang and Insel 2005, Thompson et al. 2005). Around 75\% of all drugs on the market targets GPCRs and the number is growing every year, giving a billions dollars of profit to pharmaceutical companies (Lundstrom 2005).

\subsection{G-protein mediated signaling}

Heterotrimeric G-proteins act as intracellular partners of GPCRs. The G-proteins consist of 3 subunits: $\alpha, \beta$ and $\gamma$ (Gilman 1987). The activation cycle of G-proteins involve recurrent GTP association with the alpha subunit, hydrolysis of GTP to GDP and $\mathrm{P}_{\mathrm{i}}$, followed by dissociation of GDP. Binding of GTP is associated with dissociation of the $\alpha \beta \gamma$ complex into $\alpha$ and $\beta \gamma$ subcomplexes and triggering of the appropriate effectors. The cycle is regulated by regulators of G-protein signaling or RGS proteins (Siederovski al., 1996), which bind to the Ga subunit and enhance GTP hydrolysis (Tesmer et al. 1997). Moreover, RGS proteins are recognized not only as key regulator of the signaling but also as scaffolds that coordinate parts of GPCR signaling (Figure 1.3).

The molecular weight of $\mathrm{G} \alpha$ subunits varies from 39 to $45 \mathrm{kDa}$. It possesses N-termi-

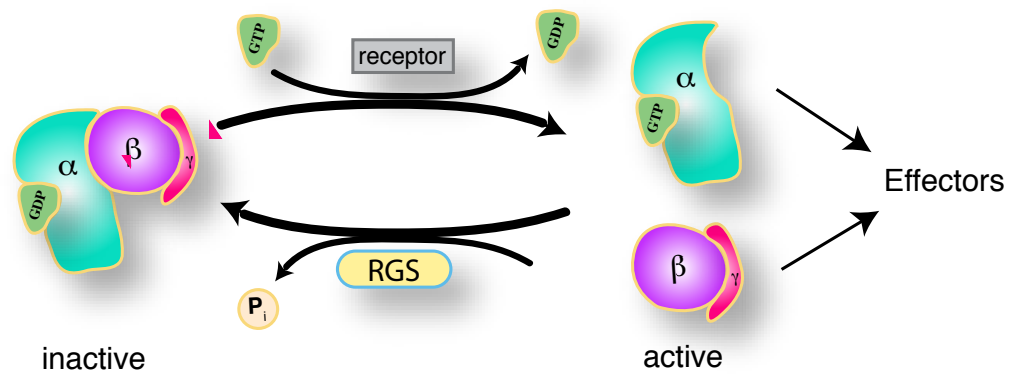

Figure 1.3 G-protein cycle. Activation of the G-protein leads to the exchange of GDP to GTP on alpha subunit, which leads to dissociation of the $\alpha$ subunit from the $\beta \gamma$ complex. Each part can trigger their own targets. RGS protein can regulate process of GDP/GTP exchange, and by this affect G-protein related signaling.

nal modifications including covalently attached fatty acids myristate (14-carbon fatty acid) and/or palmitate (16-carbon fatty acid). All Ga subunits excluding the $\mathrm{G} \alpha_{\mathrm{t}}$ or transducin 
contain palmitate reversibly attached to a cysteine on the N-terminus. Fatty acid modifications are crucial for the Ga subunit membrane localization (Peitzsch and McLaughlin 1993, Wedeetgaertner al., 1995). Based on their distinct features $\alpha$ subunits are divided into four subfamilies: $\mathrm{G} \alpha_{\mathrm{S}}, \mathrm{G} \alpha_{\mathrm{i}}, \mathrm{G} \alpha_{\mathrm{q}}$ and $\mathrm{G} \alpha_{12 / 13}$ (McCudden et al. 2005).

$\mathbf{G} \alpha_{\text {s }}$-proteins. The first identified downstream molecule, which is affected by G-proteins, was adenylate cyclases (AC). It was discovered by Sutherland in late fifties (Sutherland and Rall 1958). Twenty years later, the connection between the G-proteins and the AC was made by Ross and Gilman who isolated the $\mathrm{G} \alpha_{\mathrm{s}}$ protein and demonstarted that $\mathrm{G} \alpha_{\mathrm{s}}$ can activate AC (Ross and Gilman 1977). $\mathbf{G} \alpha_{\text {olf }}$-protein, which is a shorter (80 amino acids) version of $\mathrm{G \alpha}_{\mathrm{S}}$, also positively linked to adenylyl cyclases, is found in the olfactory system, where it serves an imperative task of olfactory signal transduction (Liu et al. 2001).

Go $\alpha_{i}$-proteins were identified by Smith and Limbrid (Smith and Limbird 1982). In contrast to $\mathrm{G} \alpha_{\mathrm{S}}$ activation of $\mathrm{G} \alpha_{\mathrm{i}}$ subunits therefore leads subsequent decrease of cAMP levels via the inhibition of AC (Albert et al. 1996, Barnes and Sharp 1999, Emerit et al. 1990, Varrault et al. 1992).

$\mathbf{G} \alpha_{\mathbf{q}}$-proteins interact with phospholipase C (PLC) isoforms (Blank et al. 1991). PLCs hydrolyze the phosphoester bond of the plasma membrane lipid phosphatidylinositol 4,5-bisphosphate, generating the ubiquitous second messengers inositol 1,4,5-trisphosphate (Ins(1,4,5)P3) and diacylglycerol (DAG).

$\mathbf{G} \alpha_{12 / 13}$ proteins activate small GTPases and are important for regulation of the cytoskeleton, cell junctions, and other processes related to cell shape movements (Collins et al. 1996, Voyno-Yasenetskaya et al. 1996, Wadsworth et al. 1997).

Up to now more than 5 different $\beta$ and $12 \gamma$ subunits have been identified (Hur and Kim 2002, McCudden et al. 2005, Nurnberg et al. 1995). G $\beta / \gamma$ subunits have a bigger variety than $G \alpha$, ensuing a bigger number of potential combinations of $G \beta / \gamma$ dimers. All $\gamma$ subunits are post-translationale modified by prenylation of the $\mathrm{C}$-terminus (Wedegaertner et al. 1995). This modification of $\mathrm{G} \gamma$ subunit works as a membrane anchor attached to the cell membrane. In early studies it has been suggested that $\mathrm{G} \beta / \gamma$ dimers serve as adaptors to promote coupling of G-protein heterotrimers to GPCRs, plus act as Ga inhibitors. Now it is widely accepted that $G \beta / \gamma$ dimers play an important role not only as adaptors but also by direct ctivation of diffirent effectors. The first proved partner for $\mathrm{G} \beta / \gamma$ dimer was G-protein regulated inward rectifier $\mathrm{K}^{+}$channels (GIRK) (Logothetis et al. 1987). Since than, many new discoveries were made, it is known that $\mathrm{G} \beta \gamma$ dimers can regulate $\mathrm{Ca}^{2+}$ channels, PLC $\beta$, p38 mitogen activated protein kinases (MAPKs), MAPK scaffold proteins, or may participate in membrane attachment of Rho and Rac. Recently it was shown that adenylate cyclases can be regulated not only by G $\alpha$, but also by $\mathrm{G} \beta \gamma$ heterodimer (Akgozuchi et al. 2002, Coso et al. 1996, Faure et al. 1994, Harhammer et al. 1996, Sunahara and Taussig 2002, Yamaet al. 1997). 


\subsection{Regulation of GPCR activity}

\subsection{1 $\beta$-arrestin mediated desensitization as the key regulatory mechanism}

The power and time of second messenger response are regulated by the process named desensitization, and almost all GPCRs undergo this process (Figure 1.4) (Claing and Laporte 2005). Desensitization starts with phosphorylation of specific serine or threonine residues by GPCR kinases (GRKs). These phosphorylation sites are located in the intracellular domains of the receptor preferentially in the receptor carboxyl terminus (Bunemann and Hosey 1999). According to the paradigm, established mainly in the $\beta 2$-adrenergic receptor system, phosphorylation on serine or threonine residues promotes $\beta$-arrestin binding to the receptor, which is recruited from the cytoplasm and serves as blocker for further receptor coupling to its G-protein (Claing and Laporte 2005).

Four different arrestins have been described so far. Two of them are found in the visual system. One is found exclusively in rods, the other one in the cones and both are involved in desensitization of the rhodopsin receptor only. Other two arrestins can be found almost in all cells. They are known as $\beta$-arrestin 1 and $\beta$-arrestin 2 and promote desensitization of most receptors (Han et al. 2001, Lohse et al. 1990). In addition to the receptor desensitization, $\beta$-arrestins also serve as adaptor proteins for receptor endocytosis and trafficking.

After being desensitized, receptors may undergo internalization, and $\beta$-arrestin plays the key role in this process by providing a link between the receptor and the endocytosis machinery. Arrestin recruits clathrin and AP-2 and controls the formation of the clathrin-coated pit. This complex recruits another protein, dynamin, which posses GTPase activity. As a vesicle invaginates, dynamin forms a spiral around the neck of the vesicle. Once the spiral is in place, it extends lengthwise and constricts through GTP hydrolysis. This lengthening and tightening of the coil around the vesicle neck causes it to break and results in formation of the endosomal vesicle. By this, receptor can be either degraded or recycled (Figure 1.4).

Noteworthy, $\beta$-arrestin proteins may act not only as adaptors during desensetizatio/internalisation process, but also can transmit signals in a cell independently of classical GPCR related signaling pathways. For example, it can recruit non-receptor tyrosine kinases of the Src family to regulate downstream cascades, such as MAPK pathway (Claing and Laporte 2005, Lohse et al. 1990).

\subsection{Serotonin receptors}

Serotonin or 5-hydroxytryptamine (5-HT) is one of major neurotransmitters in vertebrates. It was firstly described by Maurice Rapport and Irvine Page in 1948 as a substance in blood serum, responsible for contraction of blood vessels (Rapport et al. 1948), later it has been shown that serotonin may act as neurotransmitter (Twarog 1953).

In mammals, the function of 5-HT is mediated by specific receptors. With exception 


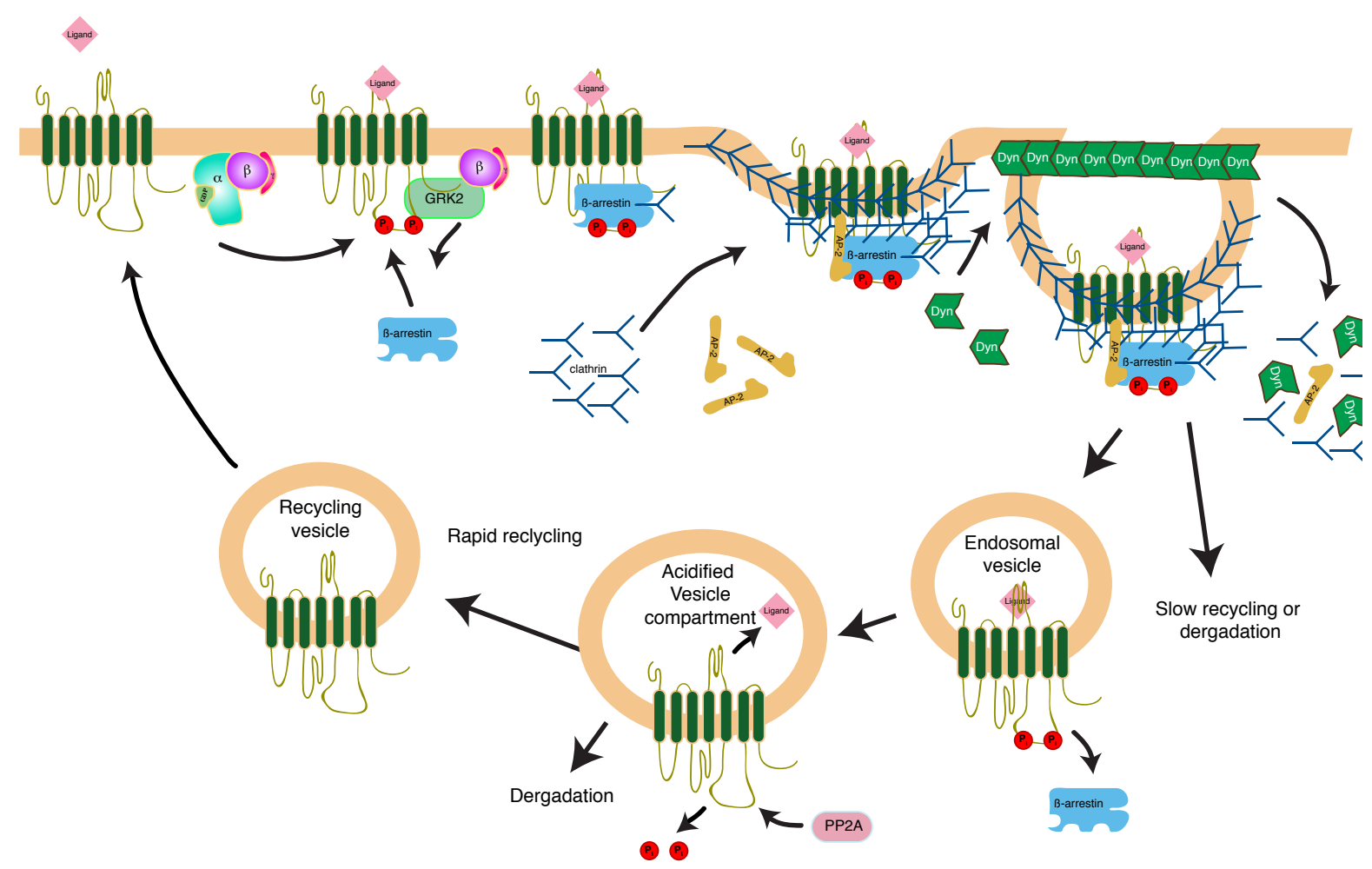

Figure 1.4 GPCR desensitization and internalization via GRK phosphorylation and $\beta$-arrestin recruitment. After receptor activation, GRK2 ( Сан2) is recruited from the cytoplasm, and phosphorylates serine/threonine residues on the $\mathrm{C}$-terminus of the receptor. Phosphorylated part of the receptor became accessible for the special adaptor protein $-\beta$-arrestin ( ylated ( $\mathbf{P}_{1}$ ) part of the receptor and makes receptor inaccessible for further G-protein related signaling. This process is known as desensitization. After desensitization, clathrin $(\prec)$ binds to a specific clathrin binding motif of the $\beta$-arrestin. Binding of clathrin to the receptor- $\beta$-arrestin complex starts a formation of clathrin-coated vesicle, which will be removed from the membrane with help of the dynamin ( Some other proteins are also involved in this process, such as AP-2 ( $)$ which is an adaptor protein. After being removed from the membrane, vesicle can go for the rapid recycling of the receptor or receptor undergoes degradation

of the 5-HT3 receptor, which is a ligand gated ion channel (Kroeze et al. 2002), all other 5-HT receptors belong to the GPCRs superfamily. The six classes of serotonin receptors are further subdivided by thirteen receptors types, based on sequence and pharmacological similarities. The serotonergic G-protein coupled receptors are typical members of the 1A family. Ligands that bind to 5-HT receptor interact with amino acids located in the transmembrane helices. Until now, the structure of the 5-HT receptors has not been solved. (Kroeze et al. 2002).

The 5-HT1A receptor is the best characterized 5-HT receptor. This receptor is coupled to heterotrimeric G-proteins of the Go $\alpha_{\mathrm{i} / \mathrm{o}}$ family (Figure 1.5) (Albert et al. 1996). Examination of G-protein specificity for the 5-HT1A receptor discovered a surprising complexity. Elimination of $\mathrm{G} \alpha_{i 1}$ abolishes receptor mediated inhibition of basal cAMP levels, whereas removal of $\mathrm{G \alpha}_{\mathrm{i} 2}$ and $\mathrm{G} \alpha_{\mathrm{i} 3}$ inhibits the 5-HT1A receptor action on $\mathrm{G} \alpha_{\mathrm{s}}$-activated ad- 


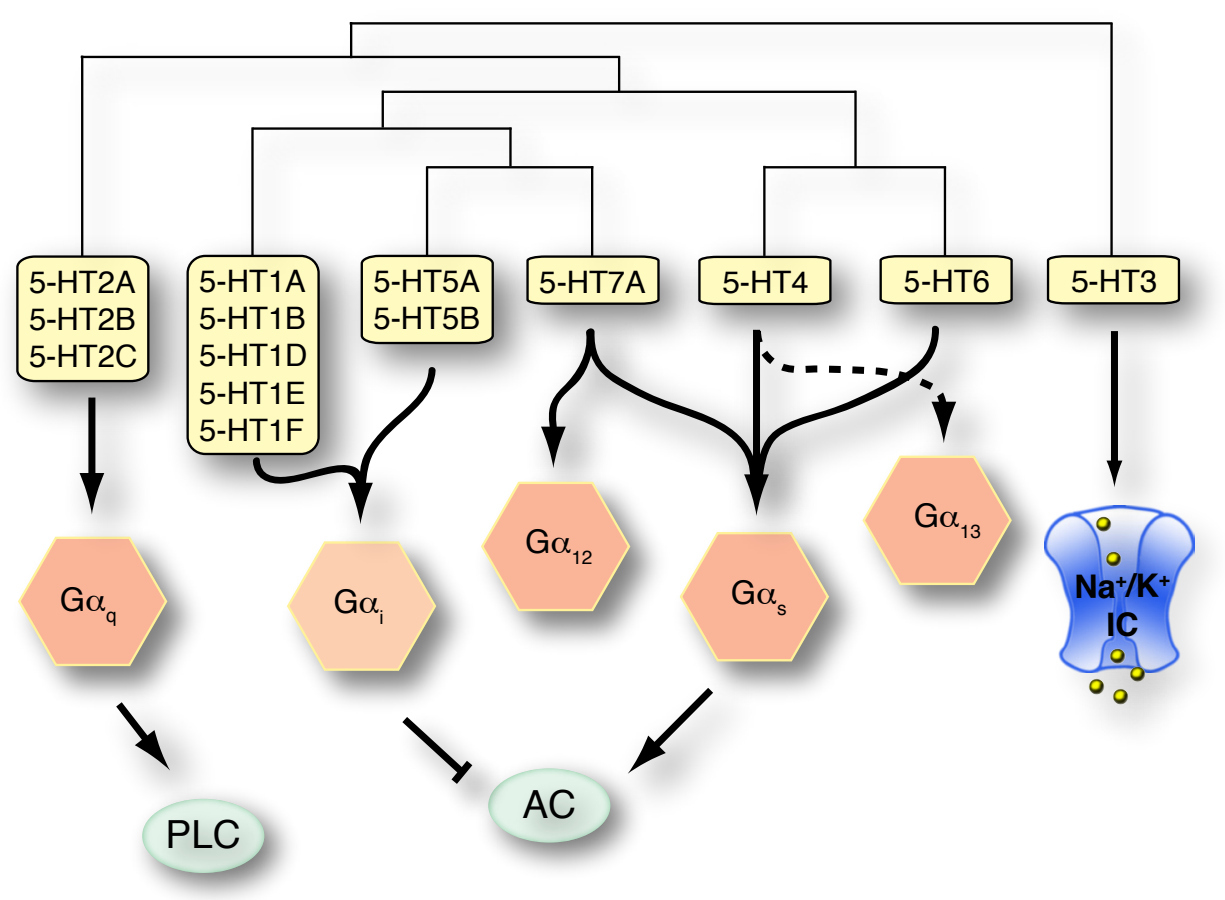

Figure 1.5 Serotonin may activate 7 distinct classes of serotonin receptors. 6 of them a are classical 7 transmembrane domain G-protein coupled receptors, and 5-HT3 is a ligand-gated $\mathrm{Na}^{+} / \mathrm{K}^{+}$channel. 5-HT1 and 5-HT5 receptors inhibit syntehisys of cAMP via activation of $\mathrm{G}_{\mathrm{i}}$; 5-HT, 5 -HT7 and 5-HT6 stimulates production of cAMP via coupling to $\mathrm{G} \alpha_{\mathrm{S}}$ protein. 5-HT2 regulates phospholipase $\mathrm{C}$ pathway via activation of

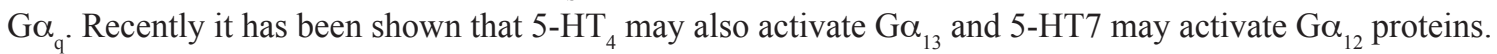

enylate cyclase (AC) (Liu et al. 1999). In addition, stimulation of the 5-HT1A receptor leads to a $\mathrm{G \alpha}_{\mathrm{i}}$-mediated activation of $\mathrm{K}^{+}$current and inhibition of $\mathrm{Ca}^{2+}$ current. In $\mathrm{CHO}$ cells, the 5-HT1A receptor also mediates G $\beta \gamma$-mediated stimulation of mitogen-activated protein kinase Erk2 as well as activation of phospholipase C (Berg and Clarke 2001, Chen et al. 2002, Cowen et al. 1996, Mendez et al. 1999). Studies in Sf.9 insect cells also gave evidences for post-translational modifications of the 5-HT1A receptor (Butkerait et al. 1995, Papoucheva et al. 2004). Significant attention to this receptor is based on studies demonstrating a role for the 5-HT1A receptor in anxiety and depression disorders (Dawson et al. 2006, Delgado et al. 2005, Fricker et al. 2005, Lanfumey and Hamon 2004).

The 5-HT2 receptor family contains three subtypes. These receptors are positively couple to $\mathrm{G} \alpha_{\mathrm{q} / 11}$ proteins and activate phospholipase C (Figure 1.5). The amino acid sequence is very similar among these receptors, but they are structurally distinct from other 5-HT receptors (Barnes and Sharp 1999). The 5-HT2 receptor can be found in the forebrain, olfactory nuclei, hippocampus, substantia nigra, and globus pallidus; outside the CNS in the lungs, and the spleen. They may regulate feeding and hormone secretion as well as locomotion and temperature control (Barnes and Sharp 1999).

The 5-HT3 receptor is distinct from all other 5-HT receptors, because it's the ligand 
gated $\mathrm{K}^{+} / \mathrm{Na}^{+}$ion channel. Until now only one gene encoding the 5-HT3 receptor was found in humans. The 5-HT3 receptor shows high level of identity to the Cys-Cys loop ligand gated ion channel superfamily (nicotinic, $\mathrm{GABA}_{\mathrm{A}}$ and glycine receptors). It can be found in the dorsal vagal compound of the brainstem, hippocampus, amygdala, and the cerebral cortex (Barnes and Sharp 1999). It may play an important role in some types of pain responses, locomotion and cognition (Koeze at al. 2002).

The 5-HT ${ }_{4}$ receptor family consist of the seven splice variants of the same gene, products of alternative splicing at the C-terminus. All of them are coupled to the $\mathrm{G \alpha}_{\mathrm{S}}$ protein which activate AC (Figure 1.5) (Barnes and Sharp 1999). The 5-HT $\mathrm{H}_{4(\mathrm{~b})}$ receptor is also coupled to $\mathrm{G \alpha}_{\mathrm{i} / \mathrm{o}}$ protein, and $5-\mathrm{HT}_{4(\mathrm{a})}$ receptor can activates $\mathrm{G} \alpha_{13}$ leading to activation of the RhoA small GTPase (Ponimaskin et al. 2002a). 5- $\mathrm{HT}_{4}$ receptors are localized in the basal ganglia, the hippocampus, the olfactory tubercule and respiratory nucleus. The 5- $\mathrm{HT}_{4}$ receptor plays a very important role in cognition and respiratory cycle (Barnes and Sharp 1999, Manzke et al. 2003). It has been shown to mediate several important physiological effects of 5-HT, including memory facilitation and the regulation of intestinal motility (Eglen et al., 1995, Bockaert et al., 1997). Mice deficient in 5-HT 4 receptors displayed abnormal stress-induced feeding and locomotor behavior, which suggests that this receptor may serve as drug target in the treatment of eating disorders (Compan et al., 2004). Moreover, 5-HT 4 receptors have been implicated in the pathogenesis of central and peripheral disorders such as neurodegenerative diseases, irritable bowel syndrome, and atrial fibrillation (Wong et al., 1996, De and Tonini, 2001, Callahan, 2002). Murine 5- $\mathrm{HT}_{4}$ receptors are coded by a complex gene that generates four carboxyl-terminal splice variants: $5-\mathrm{HT}_{4(\mathrm{a})}, 5-\mathrm{HT}_{4(\mathrm{~b})}, 5-\mathrm{HT}_{4(\mathrm{e})}$, and $5-\mathrm{HT}_{4(\mathrm{f})}$ (Claeysen et al., 1999). Cloning of 5- $\mathrm{HT}_{4}$ homologs from human and rat tissue revealed further structural diversity of this receptor (Blondel et al., 1998). All of these receptor variants share the same sequence up to the common splicing site (Leu-358), followed by a unique C terminus. All splice variants were able to stimulate adenylyl cyclase and raise intracellular cAMP levels upon agonist stimulation (Blondel et al., 1998, Claeysen et al., 1999, Bender et al., 2000, Mialet et al., 2000a, Vilaro et al., 2002), albeit with different efficacy and potency (Mialet et al., 2000a,b). Differences may also extend to the type of G-proteins to which the various splice variants are coupled. For example, it was recently showed that the $5-\mathrm{HT}_{4(\mathrm{a})}$ receptor is coupled to both $\mathrm{G} \alpha_{\mathrm{s}}$ and $\mathrm{G} \alpha_{13}$ proteins (Ponimaskin et al., 2002b), whereas the 5$\mathrm{HT}_{4(\mathrm{~b})}$ isoform activates $\mathrm{G} \alpha_{\mathrm{i}}$ and $\mathrm{G} \alpha_{\mathrm{s}}$ proteins (Pindon et al., 2002). Moreover, 5-HT $\mathrm{HT}_{4}$ receptor variants significantly differ in their sensitivity toward homologous agonist-induced desensitization (Mialet et al., 2003). Together, these results indicate that the carboxyl terminus of the 5- $\mathrm{HT}_{4}$ receptor plays an important role in G-protein coupling as well as in the initiation of counter-regulatory mechanisms.

The 5- $\mathrm{HT}_{4}$ receptors contain potential sites for post-translational modifications within their cytoplasmic carboxyl-terminal domains. It was showed previously that the $5-\mathrm{HT}_{4(\mathrm{a})}$ 
receptor is palmitoylated at two different sites, which involves a conserved cysteine pair at amino acid positions 328/329 and an unusual additional site (Cys-386) near its C terminus (Ponimaskin et al., 2002a). It was demonstrated that 5-HT $\mathrm{H}_{4(\mathrm{a})}$ receptor palmitoylation is dynamically regulated upon agonist stimulation of the receptor (Ponimaskin et al., 2001). Common to many GPCRs, acylation of 5-HT $\mathrm{H}_{4}$ receptors is believed to anchor their C-terminal tails to the plasma membrane, thereby creating additional intracellular loops.

The 5-HT5 receptor inhibits AC activity via activation of the $\mathrm{G \alpha}_{\mathrm{i} / \mathrm{o}}$ protein First variant of the 5-HT5 receptor - 5-HT5A, is expressed in human, mouse and rat; while 5-HT5B was found in the same species except the human, where its coding sequence interrupted by stop codon (Nelson 2004). (Figure 1.5). Both receptor variants can be found in neurons of carotoid body, the function of these receptors is unknown (Barnes and Sharp 1999).

The 5-HT6 receptor is positively coupled to $\mathrm{AC}$ via the $\mathrm{G} \alpha_{\mathrm{S}}$ protein. It can be found in CNS regions such as olfactory tubercules and hippocampus. Beside the brain, it's also expressed in the stomach and the adrenal glands. The 5-HT6 receptor regulates cognition, feeding, and may be involved in glutamatergic and the cholinergic activity of the neurons (Barnes and Sharp 1999).

The 5-HT7 receptors are encoded by a single gene, which generate at least four different subtypes by alternative splicing. All isoforms are positively coupled to AC and increase the cAMP formation via $\mathrm{G \alpha}_{\mathrm{S}}$ protein (Barnes and Sharp 1999). Recently it was shown shown that $\mathrm{G \alpha}_{12}$ also can be activated by the 5-HT7 receptor, this leads to the activation of small GTPases of the RhoA family (Kvachnina et al. 2005). The 5-HT7 receptors are expressed in the thalamus, the hippocampus, the hypothalamus and the cortex of the brain; At the periphery they are expressed in the smooth muscles of the blood vessels and in the gastro-intestinal tract. The 5-HT7 receptors are involved in control the circadian rhythms and the sleep (Barnes and Sharp 1999).

\subsection{Posttranslational modifications of the receptors}

GPCRs often undergo different modifications after being translated. Those modifications play very important role in regulation of GPCR activities. The main types of such posttranslational modifications include:

i. glycosylation, the addition of a glycosyl group to either asparagine, hydroxylysine, serine, or threonine, resulting in a glycoprotein

ii. phosphorylation, the addition of a phosphate group, usually to serine, tyrosine, threonine or histidine residues within the cytoplasmic receptor domains

iii. acylation, the addition of myristate or palmitate to one or several glycines or cysteines respectively to the $\mathrm{N}$ - or $\mathrm{C}$ - terminal of the protein (Figure 1.6)

iv. methylation, the addition of a methyl group, usually, to lysine or arginine residues.

(This is a type of alkylation.) 
In the present study we analysed role of acylation and possible interplay between phosphorylation and palmitoylation.

There are three classes of protein acylation in cells: S-palmitoylation, N-palmitoylation and $\mathrm{N}$-myristoylation. S-palmitoylation is the reversible addition of palmitate or other long fatty acids to a protein at cysteine residues via a thioester linkage. N-palmitoylation occurs on N-terminal cysteine residues with amide-linked palmitate. N-myrostilation occurs co-translationaly on glycine residues and is a stable modification in many cases (Linder and Deschenes 2003).

Since its discovery more than 30 years ago (Braun and Radin 1969), palmitoylation has been shown to play an important role in regulation of protein functions including protein-membrane interactions, trafficking, and enzyme activity. Up to now, two models of palmitoylation: enzymatic and non-enzymatic are widely accepted.

\subsubsection{Mechanisms of palmitoylation}

\subsubsection{Nonenzymatic S-acylation}

In 1987 O'Brien and coleagues (O'Brien et al. 1987). showed that rhodopsin might undergo spontaneous palmitoylation in a presence of palmitoyl-CoA. It is still unclear why proteins undergo spontaneous palmitoylation, because there is no identifiable consensus sequence for palmitoylation. The best evidence for the regulatory role of spontaneous S-acylation was found in mitochondria. Bovine methylmalonyl semialdehyde dehydrogenase (MMSDH) can be acylated by an [ $\left.{ }^{125} \mathrm{I}\right]$-labeled analogue of myristoyl-CoA on an active site cysteine, resulting in enzyme inhibition. This finding together with evidence that palmitoyl-CoA inhibits the activity of several mitochondrial enzymes suggests a regulatory role of S-acylation in metabolism (Linder et al. 1995, 1993, Mumby 1997, Mumby and Muntz 1995, Mumby et al. 1994).

\subsubsection{Enzymatic palmitoylation}

It is also known that palmitoylation can be an enzymatic process. Protein acyl transferase (PAT) (enzyme, responsible for palmitoylation) has been detected in membrane fractions derived from a variety of cell types. It was also found in the Golgi (Linder and Deschenes 2003). Given the diverse nature of the palmitoylated proteins, it would not be surprising if there were multiple forms of protein acyl transferases. But it very difficult to perform extensive studies on this enzyme, due to its extremely high instability. Two types of PATs were isolated from yeast using the a genetic screening. Both groups reveal cysteine rich domains containing an Asp-His-His-Cys motif, which has been shown to be very critical for their function (Akgoz et al. 2002, Fukata et al. 2004, 2006, Linder et al. 1995, 1993). 


\section{Myrostylation}

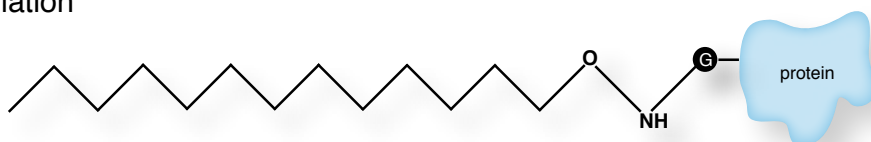

Palmitoylation

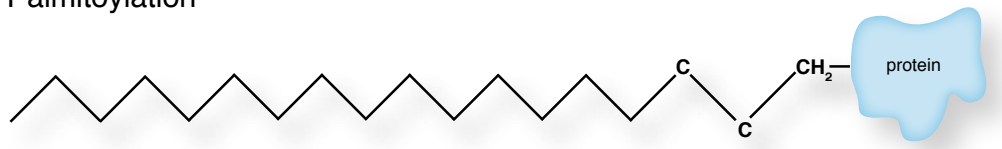

Figure 1.6 Different types of acylation. Myristoylation is a stable cotranslational modification of glycine residue by the saturated myristic acid which is atached through. Palmitoylation occurs at the cysteine residues via the thioester-type bond.

\subsubsection{Enzymatic depalmitoylation}

Since S-palmitoylation is a reversible process, there should be a mechanism by which attached palmityc acid can be removed. The finding that the rate of palmitate turnover exceeds that of the protein itself for many palmitoylated substrates suggests that protein palmitoylthioesterases, enzymes involved in depalmitoylation are also present in the cell. Two enzymes have been found and extensively characterized, a lysosomal hydroxylase, protein palmitoylthioesterase I (PPT I), and the cytoplasmic enzyme acylprotein palmitoylthioesterase I (APT I). Lysosomal localization of PPT I suggests its role in the palmitoylated protein catabolism, while cytoplasmic localization of APT I implies its role in palmitate turnover in the cytoplasm. It was also shown that APT I regulates the palmitoylation of $\mathrm{G \alpha}_{\mathrm{s}}$ protein (Linder and Deschenes 2003). Recently it was also suggested that palmitoylation of the proteins can be involved in disease processes in humans (Cho et al. 2000, Yanai et al. 2006).

\subsubsection{Palmitoylation of the G-protein coupled receptors}

It is known that proximately $80 \%$ of GPCRs contain conservative cysteine residues within their C-terminal cytoplasmic domain, which represent possible sites for palmitoylation. Palmitoylation has been also confirmed experimentally to several GPCRs. Analysis of acylation deficient mutants shows that there is no common acylation function applicable to all GPCRs (Qanbar and Bouvier 2003).

Several recent studies have suggested that palmitoylation of GPCR may play a role in the processing and targeting of the protein. Initial protein palmitoylation occurs either in an ER-Golgi intermediate compartment, or in an early Golgi compartment (Charest and Bouvier 2003). In many cases this palmitoylation appears to play an important role in the expression of functional receptors on the cell surface. For example, mutation of the palmitoylated cysteines within bovine opsin led to significant intracellular retention of the mutants when expressed in COS cells (Qanbar and Bouvier 2003). In some cases, such as the human thyrotropin receptor, delayed plasma membrane delivery of a palmitoylation-deficient mu- 
tant has been reported in the absence of measurable intracellular trapping. For some receptors the lack of palmitoylated cysteines may also be accompanied by accelerated degradation (Qanbar and Bouvier 2003). Whether these effects reflect a lack of palmitoylation in the receptor proteins or result from nonspecific conformational changes, leading to misfolding of the receptor, remains to be investigated.

For some GPCRs a dynamic agonist-dependent palmitoylation was shown (Daschem et al. 1992, Degtyarev et al. 1993, Kennedy and Limbird 1994, Ponimaskin et al., 2001). For example, stimulation of the receptor with agonist increases $\left[{ }^{3} \mathrm{H}\right]$-palmitate incorporation in 32 -adrenergic (Kennedy and Limbird 1994), 5-HT 4 (Ponimaskin et al. 2001) and human delta opioid (Petaja-Repo et al. 2006) receptors. Previous studies suggested that palmitoylation of the vasopressin receptor 2 (V2R) decreased upon stimulation (Sadeghi et al. 1997, Schulein et al. 1996). However this was not confirmed in the recent studies (Charest and Bouvier 2003).

Several studies have suggested that, in addition to processing and targeting, palmitoylation may serve other roles that relate to the signaling function of GPCRs. For example, recent studies on rhodopsin indicate that chemical depalmitoylation enhances light-dependent GTPase activity of $\mathrm{G} \alpha_{\mathrm{t}}$ and strongly decreases the light-independent activity of opsin-atr (Garnovskaya et al. 1996, Mulheron et al. 1994). Functional characterization of non-palmitoylated $\beta 2$-adrenergic and endothelin- $B$ receptors has revealed that palmitoylation is essential for agonist-stimulated coupling to $\mathrm{G} \alpha_{\mathrm{S}}$ and to both $\mathrm{G} \alpha_{\mathrm{q}}$ - and $\mathrm{G} \alpha_{\mathrm{i}}$-proteins, respectively (Moffett et al. 1993, O’Dowd et al. 1989, Okamoto et al. 1998). Analysis of the non-palmitoylated ETA receptor mutant demonstrated that ligand-induced stimulation of $\mathrm{G} \alpha_{\mathrm{S}}$ was unaffected by the lack of palmitoylation, whereas signalling through $\mathrm{G \alpha}_{\mathrm{q}}$ was prevented (O'Dowd et al., 1989). In addition, recent data on chemokine CCR5 and prostacyclin receptors also demonstrated that receptor palmitoylation is significantly involved in activation of intracellular signaling pathways (Blanpain et al. 2001, Miggin et al. 2003). We have recently demonstrated that palmitoylation of the $5-\mathrm{HT}_{4(\mathrm{a})}$ receptor modulates the agonist-independent constitutive receptor activity. We demonstrated that mutation of the proximal palmitoylation site (Cys328/29-Ser) significantly increases the capacity of receptors to convert from the inactive $(\mathrm{R})$ to the active $\left(\mathrm{R}^{*}\right)$ form in the absence of agonist. In contrast, the rate of isomerization from $\mathrm{R}$ to $\mathrm{R}^{*}$ for the Cys386-Ser as well as for the triple, non-palmitoylated mutant (Cys328/29/86-Ser) was similar to that obtained for the wild-type (Poniamskin et al. 2005). In addition, we have shown that the 5-HT1A receptor is stably palmitoylated at its C-terminal cysteine residues Cys417 and Cys420. Characterization of acylation-deficient 5-HT1A mutants revealed that palmitoylation of the 5-HT1A receptor is critical for Gi-protein coupling and effector signalling (Papoucheva et al. 2004). These findings show that receptor acylation plays differing functional roles at different receptor-G-protein interfaces, suggesting that there is no common function applicable to all GPCRs. Therefore, an analysis of the 
functions of palmitoylation is necessary for each individual receptor in order to understand its signaling mechanism.

\subsection{Aim of the study}

The main goal of this work was to study the role of palmitoylation of the 5 - $\mathrm{HT}_{4(\mathrm{a})}$ and 5-HT1A receptors for the receptor function. The following issues were analyzed:

\section{5-HT 4(a) $_{4 e c e p t o r}$}

i. mechanisms of the receptor phosphorylation

ii. interplay between acylation and phosphorylation

iii. impact of palmitoylation on the receptor desensitization and internalization

iv. function of palmitoylation on the receptor- $\beta$-arrestin 2 interaction (short term kinetic)

v. role of G-protein receptor kinase 2 on the receptor- $\beta$-arrestin 2 interaction

\section{5-HT1A receptor}

i. palmitoylation of the receptor and its function

ii. analysis of receptor localization with high spatial resolution

iii. role of microdomains in receptor signaling

iv. role of palmitoylation in receptor distirbution across the plasma membrane 


\section{Materials and methods}

\subsection{Chemicals}

Applied Biosystems: AmpliTaq Gold PCR Kit

Amersham Biosciences: ECL ${ }^{T M}$ Western Blot Detection Reagents, Nitrocellulose membrane, Blocking reagent

Genomed: Jetsorb Gel Extraktion Kit

Corning: $20 \mu \mathrm{m}$ PVDF membranes mounted in 96-well microplates

Hartmann Analytic GmbH: $\left[{ }^{3} \mathrm{H}\right]-\mathrm{GR} 11308$ (30-60 Ci/mmol)

Invitrogen: Oligonucleotide primers, Lipofectamin 2000, TC-100 medium, DMEM-

Glutamax II medium, Geneticin, FCS (Fetal Calf Serum), Trypsin, OptiMEM-1 medium

S.O.C. medium, YT medium, Superscript RT-PCR kit

Kodak: Kodak X-Omat AR film

New England Biolabs: Enzymes used in the molecular cloning

Nunc: Cell culture plastic, white 96 well plates

PerkinElmer Life Sciences: DeepBlueC substrate

Promega: EnduRen substrate, SV Total RNA isolation system, Wizard SV Genomic DNA purification system, Wizard SV Gel and PCR Clean-Up System, Coelenterazine H

Qiagen: Plasmid DNA purification Maxi Kit, HiSpeed Plasmid Midi Kit

Roth: Ammoniumpersulfat, Ampicillin (Potassium salt), TEMED, Acrylamide, BisAcrylamide, 2-Merckaptoethanol, Glycine, X-gal, IPTG, kanamycin, bromphenol blue

Sigma: 5-Hydroxytryptamine, F-12 HAM nutrient mixture, 8-OH-DPAT, Protein

A-Sepharose CL-4B beads, Gentamycin Sulfate, Kanamycine Sulfate, SDS,

Ethidiumbromide, Penicillin/Streptomycin solution, PMSF, GDP, GTP, Bacto-Tryptone,

Bacto-Yeast extract, Bacto-Agar, Total Protein Kit (Micro Loury) for the protein concentration measurements

Molecular Probes: TertraSpeck microspheres 0,2 $\mu \mathrm{m}$, fluorescent blue/green/red

\subsection{Antibodies}

\section{Abcam}

Anti-GFP - rabbit polyclonal antibodies raised against a purified Green Fluorescent Protein (GFP)

\section{Santa Cruz Biotechnology}

Anti-caveolin 1 - rabbit polyclonal antibodies raised against the $\mathrm{N}$-terminal peptide of caveolin

Anti-CD71 - rabbit polyclonal antibodies raised against the extracellular domain of the human transferrin receptor (CD71) 


\section{BD Transduction laboratories}

Anti-Caveolin 1 - mouse monoclonal antibodies

New England Biolabs

p42/44 - rabbit polyclonal antibodies raised against the mitogen-activated protein ki-

nase Erk 1/2

Anti-Rluc - rabbit polyclonal antibodies against luciferase from Renilla reniformis

$\beta$-tubulin - mouse monoclonal antibodies against $\beta$-tubulin

CD71 - mouse monoclonal antibodies against transferrin receptor

\subsection{Vectors}

Invitrogen: pcDNA3.1(-), pcDNA 3.1(+), pFastBac

Clontech: pEGFP, pEYFP, pECFP

PerkinElmer: pRluc-N2, p $\beta$-arrestin2-GFP ${ }^{2}$

\subsection{Primers for 5-HT 4 (a) cloning and sequencing}

K1529E07 5'- GCT CAC TAG TCG CGG CCG CTT TC -3'

K1529E08 5'- GTA CGG TAC CAA AGC ATG ATT CCA GAG ACT -3'

K1529E09 5'- GTA CGG TAC CAA AGG ATG ATT CCA GAG ACT -3'

K4875G06 5'- CCC TGG ACA GGT ATT ACG CC -3'

K4875G05 5'- CCT TCT TGA ATA AGT CTT TC -3'

\subsection{Solutions and buffers}

Assay buffer: $50 \mathrm{mM}$ Tris- $\mathrm{HCl}, 5 \mathrm{mM} \mathrm{MgCl}, 100 \mathrm{mM} \mathrm{NaCl}, \mathrm{pH} 7.4$

Blocking solution: $5 \%(\mathrm{w} / \mathrm{v})$ ECL blocking reagent in PBS-Tween

BRET ${ }^{2}$ assay buffer: $\mathrm{CaCl}_{2}(0.1 \mathrm{~g} / \mathrm{l}), \mathrm{MgCl}_{2} \times 6 \mathrm{H}_{2} \mathrm{O}(0,1 \mathrm{~g} / \mathrm{l}), \mathrm{D}-\mathrm{Glucose}(1 \mathrm{~g} / \mathrm{l})$

DeepBlueC stock I: $50 \mu \mathrm{g}$ of substrate, $125 \mu 1$ 100\%. ethanol, final concentration $1 \mathrm{mM}$

DeepBlueC stock II: 1:20 DeepBlueC stock I in BRET ${ }^{2}$ assay buffer, $5 \mu$ per reaction

EnduRen stock I: vial of substrate resuspended in $10 \mu 1$ of DMSO,

final concentration $60 \mathrm{mM}$

EnduRen stock II: 1:100 EnduRen stock I in cell culture medium,

final concetration $600 \mu \mathrm{M}$

HEPES-EDTA: 20 mM Hepes, 1 mM EDTA, pH 8.0

Ligand binding buffer: $50 \mathrm{mM}$ Tris (pH 7.7), $0.1 \%$ ascorbic acid, $20 \mu \mathrm{M}$ pargyline

Ligation buffer: $50 \mathrm{mM}$ Tris- $\mathrm{HCl}, 10 \mathrm{mM} \mathrm{MgCl}{ }_{2}, 10 \mathrm{mM}$ DTT, $1 \mathrm{mM}$ ATP,

$25 \mu \mathrm{g} / \mathrm{ml} \mathrm{BSA}, \mathrm{pH} 7.5$

NTEP: $0.5 \%$ NP-40 (v/v), $150 \mathrm{mM} \mathrm{NaCl}, 50 \mathrm{mM}$ Tris/HCl (pH 7.9), 5 mM EDTA, $10 \mathrm{mM}$ iodinacetamide, $1 \mathrm{mM}$ PMSF, $0.1 \%$ SDS, pH 8.4

P1 buffer: $50 \mathrm{mM}$ Tris-HCl, $10 \mathrm{mM}$ EDTA, $100 \mu \mathrm{g} / \mathrm{ml}$ RNAseA, $\mathrm{pH} 8.0$

P2 buffer: $200 \mathrm{mM} \mathrm{NaOH}, 1 \% \operatorname{SDS}(\mathrm{w} / \mathrm{v})$ 
P3 buffer: $3 \mathrm{M} \mathrm{CH}_{3} \mathrm{COONa}$, pH 5.0

PBS: $140 \mathrm{mM} \mathrm{NaCl}, 3 \mathrm{mM} \mathrm{KCl}, 2 \mathrm{mM} \mathrm{KH}_{2} \mathrm{PO}_{4}$, $\mathrm{pH} 7.4$

PBS-Tween: PBS, $0.05 \%$ (w/v) Tween 20

PCR buffer: $20 \mathrm{mM}$ Tris/HCl, $50 \mathrm{mM} \mathrm{KCl,} \mathrm{pH} 8.4$

Protein electrophoresis separation buffer: 375 mM Tris-HCl, 3.5 mM SDS, pH 8.8

TAE: $40 \mathrm{mM}$ Tris, $1 \mathrm{mM}$ EDTA, $20 \mathrm{mM}$ acetic acid, $\mathrm{pH} 8.0$

TNE buffer: 25 mM Tris-HCl, pH 7.4, 150 mM NaCl, 5 mM EDTA, 1 mM DTT, 10\% sucrose, $1 \%$ Triton X-100, 1 mM PMSF, $10 \mu \mathrm{M}$ leupeptin, $2 \mu \mathrm{g} / \mathrm{ml}$ aprotinin

Transfer buffer: $25 \mathrm{mM}$ Tris/HCl, $192 \mathrm{mM}$ glycine, 20\% methanol, $\mathrm{pH} 8.3$

TE: 0.01 M Tris-HCl, (pH 7.6 or 7.4), 1 mM EDTA, pH 8.0

Termination buffer: $50 \mathrm{mM}$ Tris- $\mathrm{HCl}, 5 \mathrm{mM} \mathrm{MgCl}$, $100 \mathrm{mM} \mathrm{NaCl}, 0,5 \% \mathrm{NP}-40,1 \%$ aprotinin, $100 \mu \mathrm{M}$ GDP, $100 \mu \mathrm{M}$ GTP, pH 7.4

Protein electrophoresis stacking buffer: 125 mM Tris-HCl, 3.5 mM SDS, pH 6.8

Protein loading buffer: $31 \mathrm{mM}$ Tris/ $\mathrm{HCl}, 10 \%$ Glycerin, 3\% SDS,

$0.05 \%$ bromphenolblue, $\mathrm{pH} 8.8$

QBT buffer: $750 \mathrm{mM} \mathrm{NaCl}, 50 \mathrm{mM}$ MOPS, $15 \%$ isopropanol, $0.15 \%$,

Triton X-100, pH 7.0

QC buffer: $1 \mathrm{M} \mathrm{NaCl}, 50 \mathrm{mM}$ MOPS, $15 \%$ isopropanol, $\mathrm{pH} 7.0$

QF buffer: 1,25 M NaCl, $50 \mathrm{mM}$ Tris- $\mathrm{HCl}, 15 \%$ isopropanol, $\mathrm{pH} 8.5$

Restriction buffer 1: $20 \mathrm{mM}$ Tris- $\mathrm{HCl}, 10 \mathrm{mM} \mathrm{MgCl} 2,1 \mathrm{mM}$ DTT, $\mathrm{pH} 7.0$

Restriction buffer 2: $50 \mathrm{mM} \mathrm{NaCl}, 10 \mathrm{mM}$ Tris-HCl, $10 \mathrm{mM} \mathrm{MgCl}$, 1 mM DTT, pH 7.9

\subsection{Recombinant DNA procedures}

The basic DNA procedures were performed as described by Sambrook et al.

(Sambrook et al. 1989).

\subsubsection{Construction of 5- $\mathrm{HT}_{4(\mathrm{a})}-\mathrm{Rluc}$ fusion protein}

The PCR primers were designed using the Vector NTI 10.0 software (InforMaxInc, 1994-2005). Fragments were amplified from pFastBac-5-HT $4(\mathrm{a})(\mathrm{Wt}, \mathrm{C} 328 / 29 \rightarrow \mathrm{S}, \mathrm{C} 386 \rightarrow$ $\mathrm{S}, \mathrm{C} 328 / 29 / 86 \rightarrow \mathrm{S}$ ) vectors with primers K1529E07 and K1529E08 for 5-HT $4(\mathrm{a})$ type; K1529E07 and K1559E09 for the p5-HT ${ }_{4(\mathrm{a})} \mathrm{C} 328 / 29 \rightarrow \mathrm{S}, \mathrm{C} 386 \rightarrow \mathrm{S}, \mathrm{C} 328 / 29 / 86 \rightarrow$ $\mathrm{S}$ mutants under the following conditions: HotStart ${ }^{\mathrm{TM}}$ activation for 5 minutes at $94^{\circ} \mathrm{C}$ followed by 35 cycles of amplification $\left(94^{\circ} \mathrm{C}\right.$ for 45 seconds - denaturation, $55^{\circ} \mathrm{C}$ for $56 \mathrm{sec}-$ onds - annealing, $72^{\circ} \mathrm{C}$ for 60 seconds - extension), final extension at $72^{\circ} \mathrm{C}$ for 5 minutes.

\subsubsection{Agarose gel electrophoresis and fragment purification}

The DNA fragments were separated by agarose gel electrophoresis. The $1 \%$ agarose gels were prepared with TAE buffer and contained ethidium-bromide (EtBr) at final concentration of $0.5 \mu \mathrm{g} / \mathrm{ml}$. After the separation DNA bands were visualized under ultraviolet 
light. Ethidium-bromide stained bands of DNA were excised from the gel and purified with the JetSorb DNA extraction kit or Wizard SV Gel and PCR Clean-Up System according the manufacturer's protocol.

\subsubsection{Preparation of PCR products for cloning}

Purified PCR product was treated with the restriction endonuclease KpnI and EcoRI to prepare the fragments with the "sticky" DNA ends for efficient cloning in the expression vector. The total volume of the reaction mixture was $50 \mu 1$. This mixture contained restriction buffer 2, $100 \mu \mathrm{g} / \mathrm{ml} \mathrm{BSA,} 1 \mathrm{mg}$ of the purified PCR product and 1.5 units $\mathrm{KpnI}$ and 1 units of EcoRI. The reaction was performed at $37^{\circ} \mathrm{C}$ for $60 \mathrm{~min}$. The DNA fragments were separated by agarose gel electrophoresis and purified by the JetSorb kit or Wizard SV Gel and PCR Clean-Up System prior to the ligation.

\subsubsection{Preparation of expression vectors for cloning}

Expression vector (pRluc-N2, PerkinElmer) was digested with the restriction endo-

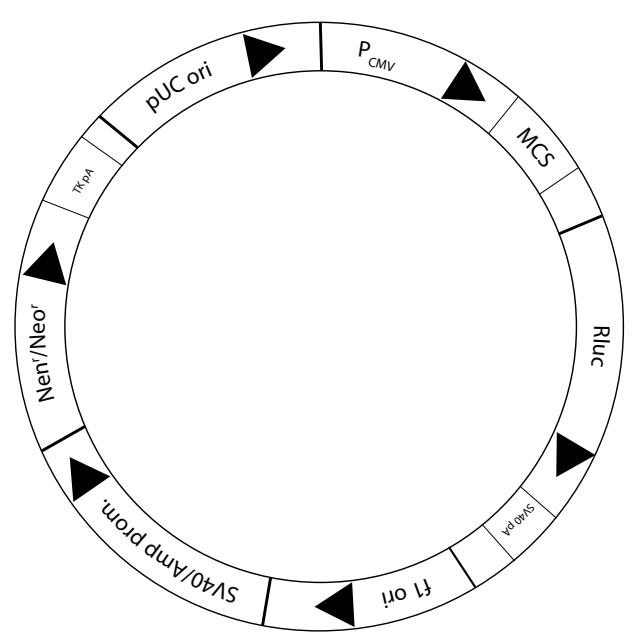

Figure 2.1 pRluc-N2 vector map. $5-\mathrm{HT}_{4(\mathrm{a})}$ PCR fragment (1.2 kbp) was cloned into pRluc-N2 vector on KpnIEcoRI restriction sites of the pRluc-N2 (5.4 kb) (MCS - multicloning site). nucleases KpnI and EcoRI as described above (Figure 2.1). After digestion, enzymes was inactivated by incubation at $65^{\circ} \mathrm{C}$ for $20 \mathrm{~min}$. "Sticky" ends of the digested expression vectors were dephosphorylated by incubation with 10 units of calf intestinal phosphatase to prevent self-ligation of the vector for 1 hour at $37^{\circ} \mathrm{C}$. The digested and dephosphorylated vectors were purified as described above.

\subsubsection{Ligation}

Ligation reactions were performed for 2 hours at RT or for over night at $+4^{\circ} \mathrm{C}$ in $20 \mu \mathrm{l}$ final volume and contained the ligation buffer, $5 \mathrm{ng}$ of the digested vector, 20-100 ng of the digested PCR product and 8 units of T4 DNA ligase. The ligation mixture was used directly for transformation of the $\mathrm{DH} 5 \alpha$ competent cells.

\subsubsection{Transformation}

The competent cells were thawed on ice and placed into 12-ml polypropylene tubes. $20 \mu \mathrm{l}$ of the ligation mixture were added to $50 \mu \mathrm{l}$ of competent cells and mixed. After incubation for 30 minutes on ice, the cells were heat-shocked for 92 seconds at $37^{\circ} \mathrm{C}$ and placed on ice for 2 minutes, mixed with $800 \mu \mathrm{l}$ of SOC medium and incubated for 1 hour at $37^{\circ} \mathrm{C}$. 
The cells were collected by centrifugation and plated on the YT medium agar plates supplemented with appropriate selective antibiotics. The plates were incubated overnight at $37^{\circ} \mathrm{C}$.

\subsubsection{Analysis of the clones}

The bacterial colonies were collected with the sterile pipette tip and grown in $2 \mathrm{ml}$ of the YT medium with the respective antibiotics by overnight shaking at $37^{\circ} \mathrm{C}$. The plasmid DNA was isolated from the overnight culture by the alcaline lysis method. The bacterial cells were centrifugated (1000x g for 5 minutes) and resuspended in $0.2 \mathrm{ml}$ of the RNAsecontaining buffer P1. The cells were lysed by addition of an equal volume of the lysis buffer P2 and incubated for 5 minutes at RT. The genomic DNA was then precipitated by addition of $0.2 \mathrm{ml}$ of the buffer $\mathrm{P} 3$ ( $\mathrm{pH}$ 5.5). The precipitated genomic DNA was removed by centrifugation for 10 minutes at $20000 \mathrm{x}$ g at $4^{\circ} \mathrm{C}$. The plasmid DNA was precipitated from the supernatant by addition of isopropanol to $45 \%$ final concentration and centrifuged for 10 minutes at $20000 \mathrm{x}$ g, washed with 70\% ethanol, air-dried and dissolved in $50 \mu \mathrm{l}$ of TE buffer ( $\mathrm{pH}$ 8.0). Orientation of the inserts was analyzed by digestion of the plasmid DNA with the restriction endonuclease BamHI. The reactions were performed in $50 \mu 1$ at $37^{\circ} \mathrm{C}$ for $30 \mathrm{~min}$ utes. Each reaction mixture contained the restriction buffer 2,500 ng of the DNA and 1U of the BamHI. The digestion products were analyzed by agarose gel electrophoresis.

\subsubsection{Propagation and purification of the plasmid DNA}

The clones with the correct insert orientation were selected for plasmid amplification. For that, $200 \mu \mathrm{l}$ of the overnight culture was inoculated in $100 \mathrm{ml}$ of the YT medium containing the respective antibiotic and incubated overnight under shaking at $37^{\circ} \mathrm{C}$. The plasmid DNA was isolated using HiSpeed Plasmid Midi Kit (Qiagen). The plasmid DNA precipitate was washed with $70 \%$ ethanol, air-dried and diluted in $1 \mathrm{ml}$ of TE (pH 8.0). The procedure yielded about $1 \mu \mathrm{g} / \mu 1$ of the pure plasmid DNA. The purified plasmid DNA was used for sequence analysis and for cell transfection.

\subsection{Cell culture and transfection}

\subsubsection{Culturing of the Sf.9 insect cells}

The Sf.9 cells were grown in $75-\mathrm{mm}^{2}$ flasks in $10 \mathrm{ml}$ of TC-100 medium supplemented with $10 \%$ of FCS and $1 \%$ of penicillin-streptomycin (PS) at $28^{\circ} \mathrm{C}$. For sub-culturing, the medium was removed, the cells were scraped from the flask into $6 \mathrm{ml}$ of fresh TC-100 medium, resuspended and one sixth of the suspension was transferred into the new flask.

\subsubsection{Infection of the Sf.9 cells with baculovirus}

The Sf.9 cells $\left(10^{6}\right.$ cells) were plated on $35 \mathrm{~mm}$ dishes one day before the infection and incubated in a humid chamber at $28^{\circ} \mathrm{C}$. Next day the cells were infected with $10^{5}$ plaque 
forming units (pfu) of the purified baculovirus. The cells were incubated with the virus for $60 \mathrm{~min}$, being rocked every 15 minutes. After the incubation, the virus-containing medium was replaced by TC-100 supplemented with $10 \%$ FCS and $1 \%$ PS. The cells were used for analysis 48 hours after the infection.

\subsubsection{Culturing of the mammalian cells}

The NIH-3T3 or HEK 293 cells were cultured in the DMEM medium supplemented with GlutaMAX II, $10 \%$ of FCS and $1 \%$ of PS on $10 \mathrm{~cm}$ plates or in T-75 flasks. The CHO-K1 cells were cultured in the F-12 HAM medium supplemented with $10 \%$ of FCS and $1 \%$ of PS. The N1E cells were cultured in the neurobasal medium supplemented with $10 \%$ of FCS and 1\% of PS. For subculturing, the cells were treated with $3 \mathrm{ml}$ of $0,05 \%$ (w/v) trypsin $/ 0.02 \%(\mathrm{w} / \mathrm{v})$ EDTA, resuspended in $6 \mathrm{ml}$ of the respective medium and 1/10 of the cell suspension was seeded on the new plate. HEK 293 cells were detached using a plastic scraper. All mammalian cells were grown at $37^{\circ} \mathrm{C}, 5 \% \mathrm{CO}_{2}$ and $95 \%$ humidity and medium was changed twice a week (Freshney 2000).

\subsubsection{Transient transfection of the mammalian cells}

The cells $\left(10^{6}\right.$ cells per dish) were plated on $35 \mathrm{~mm}$ dishes one day before the transfection. $10 \mu \mathrm{l}$ of Lipofectamine 2000 were diluted in $250 \mu \mathrm{l}$ of the OptiMEM-1 medium and incubated at RT for 5 minutes. $3 \mu \mathrm{g}$ of the $5-\mathrm{HT}_{4(\mathrm{a})}-\mathrm{Rluc}$ plasmid and $6 \mu \mathrm{g}$ of $\beta$-arrestin2GFP $^{2}$ were diluted in $250 \mu 1$ of the OptiMEM medium and mixed with the Lipofectamine 2000 solution. Mixture was incubated for $20 \mathrm{~min}$ at RT to form DNA/Lipofectamine complexes. After the incubation, $500 \mu 1$ of the DNA/Lipofectamine 2000 complexes were mixed with $1.5 \mathrm{ml}$ of the culture medium containing $10 \%$ FCS and added to the cells for 8 hours and then replaced by the culture medium with $10 \%$ FCS and $1 \%$ PS.

\subsubsection{Stable transfection of the mammalian cells}

The CHO-K1 cells were transfected using Lipofectamine 2000. One day after the transfection, the cells were trypsinized and $1 / 20$ part of the cell suspension was plated on $100 \mathrm{~mm}$ dishes. Twenty four hours after the split, the selective antibiotic Geneticin was added to the culturing media (DMEM, 10\% FCS, 1\% PS) at the final concentration of $1 \mathrm{mg} /$ $\mathrm{ml}$. The concentration of Geneticin was adjusted by dose-response analysis. The cells were grown in the selective medium for two weeks. During the incubation, the medium was exchanged every 3 days. Single colonies were collected by the sterile pipette tip and plated on separate $100 \mathrm{~mm}$ dishes. The stably transfected cell lines were tested for the expression of the recombinant protein by immunoblot analysis. The amount of the receptor surface expression was analyzed for the selected positive lines by specific radioligand binding. 


\subsection{Protein analysis}

\subsubsection{SDS-polyacrylamide gel electrophoresis}

Twelve percent gels were used for the separation of proteins using SDS-polyacrylamide gel electrophoresis (SDS-PAGE). The proteins were solubilized in sample buffer, loaded on to the gel and separated by the application of electrical field. To define the protein size, a molecular weight marker was loaded in parallel.

\subsubsection{Immunoblot}

After completion of the electrophoresis, gel was removed, pre-equilibrated in the transfer buffer (25 mM Tris/HCl, $192 \mathrm{mM}$ glycine, 20\% methanol, $\mathrm{pH} 8.3$ ) and placed on top of the nitrocellulose membrane $(0.2 \mu \mathrm{m}$ pore diameter). Three sheets of Whatman filter paper pre-soaked in the transfer buffer were placed above and below the gel and the membrane. Transfer of proteins to the membrane was performed by application of $3 \mathrm{~mA}$ current per $1 \mathrm{~cm}^{2}$ for 2 hours. After the transfer, the membrane was incubated in blocking solution over night at $4{ }^{\circ} \mathrm{C}$ on the rocking platform and incubated with the primary antibodies dissolved in PBS/0.5\% Tween for 1 hour at room temperature. The membranes were washed 3 times for 20 minutes with PBS-Tween, incubated with the secondary antibodies for 1 hour at room temperature, washed again and subjected to the detection. For protein detection, the chemiluminescent ECL Western Blotting Detection system (Amersham Biosciences) was used. The protein bands were visualized by exposure of nitrocellulose membrane to the Kodak-XOMAT AR films.

\subsubsection{Phosphorylation experiments}

Spodoptera frugiperda (Sf.9) cells were infected with recombinant baculovirus encoding wild-type or mutated $5-\mathrm{HT}_{4(\mathrm{a})}$ receptors. Labeling experiments were started after 48 hours of incubation. One hour before labeling, complete TC-100 was replaced by phosphate-free TC-100 medium, and cells were labeled with ${ }^{32} \mathrm{P}_{\mathrm{i}}$ (Freedman et al. 1997) (150 $\mu \mathrm{Ci} / \mathrm{ml}$ ) for the time periods indicated in the figure legends. In some experiments, $5-\mathrm{HT}$, forskolin, PMA, A23187, or staurosporin were added to final concentrations $10 \mu \mathrm{M}, 50$ $\mu \mathrm{M}, 200 \mathrm{nM}, 10 \mu \mathrm{M}$ or $1 \mu \mathrm{M}$, respectively. After labeling, cells were washed twice with ice-cold PBS and lysed in $600 \mu \mathrm{l}$ of NTEP buffer containing $10 \mathrm{mM}$ sodium fluoride and $10 \mathrm{mM}$ disodium pyrophosphate. Insoluble material was pelleted ( $5 \mathrm{~min}$ at $15000 \mathrm{x} \mathrm{g}$ ), and the antibody AS9459 against the C-terminal domain of the 5- $\mathrm{HT}_{4(\mathrm{a})}$ receptor (Ponimaskin et al. 2001) was added to the supernatant together with $30 \mu 1$ of protein A-Sepharose CL-4B. Samples were incubated under gentle rotation for 4 hours. After brief centrifugation, the pellet was washed three times with ice-cold buffer $\mathrm{A}$, and the immunocomplexes were released from the beads by incubation for $30 \mathrm{~min}$ at $37^{\circ} \mathrm{C}$ in nonreducing electrophoresis sample buffer $(62.5$ mM Tris-HCl, pH 6.8, containing 20\% glycerol, $6 \%$ SDS, and $0.002 \%$ bromphe- 
nol blue). Radiolabeled polypeptides were analyzed by SDS-PAGE on 12\% acrylamide gels and visualized by autoradiography. The expression of 5-HT $\mathrm{H}_{4(\mathrm{a})}$ receptors was analyzed in parallel by immunoblot analysis with antibodies AS9459 at a 1:1000 dilution. The amount of $\left[{ }^{32} \mathrm{P}_{\mathrm{i}}\right]$-phosphate incorporated into each of these mutants was then calculated by autoradiographic analysis in relation to the expression level of the various proteins as assessed by densitometric analysis of immunoblots (Freedman et al. 1997).

\subsubsection{Phosphoamino acid analysis}

For the determination of phosphoamino acids, $\left[{ }^{32} \mathrm{P}_{\mathrm{i}}\right]$-labeled Sf.9 cells $\left(3 \times 10^{6}\right.$ cells per 60-mm dish) expressing 5-HT $\mathrm{H}_{4(\mathrm{a})}$ receptor wild-type or its acylation-deficient mutants were treated for $5 \mathrm{~min}$ with $10 \mu \mathrm{M}$ 5-HT. Receptors were immunoprecipitated with the receptor-specific antibody AS9459 and resolved by SDS-PAGE on a 12\% polyacrylamide gel. After electrophoretic transfer to a polyvinylidene difluoride membrane (Immobilon; Millipore Corporation (Bedford, MA) and autoradiography, receptors were excised and hydrolyzed in $6 \mathrm{~N} \mathrm{HCl}$ for 2 hours at $110^{\circ} \mathrm{C}$. Hydrolysates were vacuum-dried, resolubilized in $\mathrm{pH} 1.9$ buffer (formic acid/acetic acid/ $\mathrm{H}_{2} \mathrm{O}, 10: 100: 1890$ (v/v/v)) containing phosphoamino acid standards and spotted on a thin-layer cellulose plate. Phosphoamino acids were separated by electrophoresis $(900 \mathrm{~V} / 1,5 \mathrm{~h})$ at $\mathrm{pH} \mathrm{1.9}$, followed by a second electrophoresis (900 $\mathrm{V} / 45 \mathrm{~min}$ ) at $\mathrm{pH} 3,5$ (pyridine/acetic acid/ $\mathrm{H}_{2} \mathrm{O}, 10: 100: 1890(\mathrm{v} / \mathrm{v} / \mathrm{v})$ and 0.5 mM EDTA) in the orthogonal direction. After ninhydrin staining of phosphoamino acid standards, thinlayer plates were exposed to autoradiographical screens and analyzed by filmless autoradiographic analysis.

\subsubsection{Co-patching assay}

For preparation of membrane sheets, stably transfected NIH-3T3 cells were treated according to Avery et al. (Avery et al. 2000). Briefly, cells grown on coverslips were disrupted by $10 \mathrm{~ms}$ sonication in ice-cold KGlu buffer (120 mM K-glutamate, $20 \mathrm{mM} \mathrm{K}$-acetate, $20 \mathrm{mM}$ HEPES pH 7.2). Co-patching of YFP-fused receptor and GM1 was carried out by simultaneous incubation of unfixed membrane sheets with goat anti-GFP antibody (Abcam; 1:1000 dilution) and cholera-toxin (Sigma, $1 \mu \mathrm{g} / \mathrm{ml}$ ). Incubation was performed in KGlu buffer containing $0.5 \%$ BSA for $60 \mathrm{~min}$ at $37^{\circ} \mathrm{C}$. Membranes were washed and fixed in 4\% PFA for 60 minutes. The fixed sheets were incubated with mouse anti-CTX antibodies at 1:1000 dilution, followed by incubation with Alexa Fluor 546-conjugated rabbit anti-mouse antibody (1:500). Before imaging, membranes were stained with TMA$\mathrm{DPH}$, which was directly added to the bath solution. For cholesterol depletion, membrane sheets were treated for 10 min with $5 \mathrm{mM}$ methyl- $\beta$-cyclodextrin (Sigma) in KGlu buffer prior co-patching procedure. For the line scan analysis, membrane sheets were imaged using Zeiss Axiovert 100 TV fluorescence microscope with a 100x1.4 NA Plan-Achromate objective and a back-illuminated frame transfer CCD-camera. Membrane sheets were im- 
aged in three channels, blue for TMA-DPH (430 nm), green for 5-HT1A-YFP (515 nm) and red for Alexa546-CTX (546 nm), whereas TMA-DPH staining was used to select intact membrane sheets for the analysis. Red and green channels were aligned by color align function of MetaMorph software (Universal Imaging, West Chester, PA, USA) using fluorescent beads (TetraSpec microspheres $0.2 \mu \mathrm{m}$, Molecular Probes) which have been added to every membrane preparation. For co-localization analysis, 20 lines ( 25 pixels/line) per image were drawn across clustered receptors, while red channel was switched off. Distance between red and green pixels at maximal intensity was determined in each line on the merge pictures using line scan function of the MetaMorph software and when the distance was less than two pixels, a co-localization event was counted. For normalization, the counting protocol was repeated after horizontal flipping of the red channel.

\subsubsection{GTP $\gamma$ S binding}

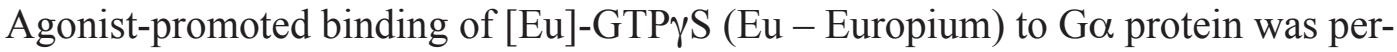
formed according to the method described by Barr et al. (Barr et al. 1997). Briefly, $10 \mu \mathrm{g}$ of membranes from transfected N1E cells were resuspended in $55 \mu 1$ of $50 \mathrm{mM}$ Tris- $\mathrm{HCl}$ (pH 7.4) containing $2 \mathrm{mM}$ EDTA, $100 \mathrm{mM} \mathrm{NaCl}, 3 \mathrm{mM} \mathrm{MgCl}, 1 \mu \mathrm{M}$ GDP and $10 \mu \mathrm{M}$ of agonist, and incubated at RT for $10 \mathrm{~min}$. After adding [Eu]-GTP $\gamma \mathrm{S}$ (PerkinElmer) to a final concentration of $10 \mathrm{nM}$ samples were incubated for 1.5 hours at RT. The reaction was terminated by adding $600 \mu \mathrm{l}$ of $50 \mathrm{mM}$ Tris- $\mathrm{HCl}$ (pH 7.5) containing $20 \mathrm{mM} \mathrm{MgCl}, 150 \mathrm{mM}$ $\mathrm{NaCl}, 0.5 \% \mathrm{NP}-40,200 \mu \mathrm{g} / \mathrm{ml}$ aprotinin, $100 \mu \mathrm{M}$ GDP and $100 \mu \mathrm{M}$ GTP and incubated for $15 \mathrm{~min}$ on the ice. The samples were incubated for 1.5 hours with $10 \mu 1$ of antibody raised against $\mathrm{G \alpha}_{\mathrm{i} 3}$ (SantaCruz) followed by 1.5 hours at RT with $30 \mu \mathrm{l}$ of Sepharose-Protein $\mathrm{G}$ (Sigma). Immunoprecipitates were washed three times, heated at $37^{\circ} \mathrm{C}$ for $15 \mathrm{~min}$ in $0.2 \mathrm{ml}$ of $0.5 \%$ SDS, then centrifuged and supernatans were subjected to the fluorescense detection. Fluorescence of [Eu]-GTP $\gamma \mathrm{S}$ was measured at $615 \mathrm{~nm}$ in fluorescent plate reader Mithras LB680 (Berthold) (Exitation $315 \mathrm{~nm}$, emmision $615 \mathrm{~nm}$ ).

\subsubsection{Immunocytochemistry and imaging}

Forty eight hours after the transfection, cells grown on coverslips were fixed with paraformaldehyde (3\% in PBS) for $15 \mathrm{~min}$. The paraformaldehyde was quenched with 50 $\mathrm{mM}$ glycine for $15 \mathrm{~min}$ and the cells were washed three times with PBS. The cells were permeabilized with $0.1 \%$ Triton-X100 for 2 min and incubated for 1 hour with antibodies diluted in PBS containing 3\% BSA. The secondary antibodies were applied for 1 hour with subsequent washing in PBS. Finally, coverslips were mounted mounting medium. The cells were imaged with the confocal laser-scaning microscope LSM510-Meta (Zeiss). All image analysis and manipulations were done in Photoshop CS2, Illustrator CS2 (Adobe) and MetaMorph. 


\subsubsection{BRET $^{2}$ assay}

All BRET measurements were made in CHO or HEK 293 cells co-expressing $5-\mathrm{HT}_{4(\mathrm{a})}$-Rluc and $\beta$-arrestin2-GFP ${ }^{2}$ constructs. Forty eight hours after transfection, cells were washed with PBS and resuspended in BRET assay buffer at $37^{\circ} \mathrm{C}$. Cells (approximately $1 \times 10^{5}$ cells per well) were diluted in $40 \mu 1$ of BRET assay buffer and spread in white 96 well plates (Nunc) and incubated in the presence or absence of 5-HT (added volume $5 \mu \mathrm{l})$ for 2 min except in the case of the kinetical studies. Five microliters of DeepBlueC stock II (final concentration $5 \mu \mathrm{M}$ ) were added, and readings were collected using Mithras LB650 (Berthold) under the control of MikroWin2000 software. The BRET signal was determined by calculating the ratio of the light emitted by $\mathrm{GFP}^{2}(515 \mathrm{~nm})$ over the light emitted by the Rluc (400 $\mathrm{nm}$ ). The normalized BRET values were obtained by subtracting the BRET background signal detected when 5-HT $\mathrm{H}_{4(\mathrm{a})}$ - Rluc construct was expressed alone. The expression level of the receptor was determined by incubation of cells with CoelenterazineH (Promega) for $10 \mathrm{~min}$ at a final concentration of $5 \mu \mathrm{M}$, and the total luminescence of cells was measured. All BRET data was normalized to these values. In contrast to DeepBlueC, Coelenterazine, coelenterazine $\mathrm{H}$ does not lead to energy transfer between Rluc and GFP 2 and thus allows evaluation of the receptor expression.

For kinetic analysis of $5-\mathrm{HT}_{4(\mathrm{a})}$ and $\beta$-arrestin2 interactions, EnduRen stock II solution was added before the injection of the 5-HT and the data were collected every 0.5 second. Injection of the 5-HT was included within the kinetical program to allow baseline recording followed by real-time recording of the BRET changes. Curves were fitted using a non-linear regression using GraphPad Prism software.

\subsubsection{Ligand binding experiments}

The NIH $3 \mathrm{~T} 3$ or CHO cells transfected with the receptor constructs were grown on 24-well plates, starved in the respective medium without FCS for 16 hours prior to the assay and washed twice with ice-cold PBS. For the ligand binding, the cells were incubated with $50 \mathrm{nM}\left[{ }^{3} \mathrm{H}\right]$-GR 11308 diluted in culture medium containing $0.2 \%$ BSA for 60 minutes on ice. The cells were washed 5 times with ice-cold PBS and lysed in $0.2 \mathrm{M} \mathrm{NaOH}$. The bound radioactivity was measured by the scintillation counter. Non-specific binding was determined by the addition of $100 \mu \mathrm{M}$ unlabeled 5-HT. The protocol is modified from Varrault and colleagues (Varrault et al. 1992). 


\subsection{Data analysis}

For data analysis we used two different equations. First equation was used to obtain raw data on receptor- $\beta$-arrestin2 interaction (Angers et al. 2000, Charest and Bouvier 2003). BRET data was represented as ratio between luminescence signal of $\beta$-arrestin2-GFP', over

$$
\mathrm{BRET}^{2} \text { ratio }=\frac{\beta-\mathrm{arrestin}_{2}-\mathrm{GFP}^{2}}{5-\mathrm{HT}_{4(\mathrm{a})}-\mathrm{Rluc}}-5-\mathrm{HT}_{4(\mathrm{a})}-\mathrm{Rluc}^{(e q .1)}
$$

luminescence of receptor-Renilla luciferase, minus luminescence of receptor-Renilla luciferase expressed alone.

$$
\mathrm{q}(\mathrm{t})=\mathrm{q}(\mathrm{t} \rightarrow \infty)+\mathrm{q}(\mathrm{t}=0) \cdot e^{(-\mathrm{R}) \mathrm{t}} \quad(\text { eq. } 2)
$$

To estimate half time of $\beta$-arrestin2 recruitment, linear part of the curve generated by equation 2 was analyzed (Charest and Bouvier 2003).

Where $t$ is the time of observation, $R$ is the rate, and q represents the level of $\beta$-arrestin2 recruitment. 


\section{Results}

\subsection{Role of the palmitoylation in $5-\mathrm{HT}_{4(\mathrm{a})}$ receptor functioning}

\subsubsection{Phosphorylation of the 5- $\mathrm{HT}_{4(\mathrm{a})}$ receptor}

G-protein coupled receptors (GPCRs) often undergo agonist-induced phosphorylation, which is functionally linked to receptor desensitization. Therefore we studied, whether the $5-\mathrm{HT}_{4(\mathrm{a})}$ receptor is phosphorylated upon agonist stimulation. For that recombinant $5-\mathrm{HT}_{4(\mathrm{a})}$ receptor was expressed in Sf.9 insect cells using baculovirus system. Infected cells were incubated with $\left[{ }^{32} \mathrm{P}_{\mathrm{i}}\right]$ to label their ATP pool and then exposed to the 5-HT receptor agonist 5-HT (10 $\mu \mathrm{M}, 10 \mathrm{~min})$. After immunoprecipitation and SDS-PAGE, the receptor was analyzed by autoradiography as described in Materials and Methods. As shown in Figure 3.1A, exposure of the receptor to 5-HT promoted the phosphorylation of a single protein band with a molecular weight of approximately $42 \mathrm{kDa}$ corresponding to the predicted molecular mass of the $5-\mathrm{HT}_{4}$ receptor. This band co-migrated with the $5-\mathrm{HT}_{4(\mathrm{a})}$ protein band detected by the immunoblot and was absent in noninfected, $\left[{ }^{32} \mathrm{P}_{\mathrm{i}}\right]$-labeled control cells. To examine the dose dependence of ${ }^{32} \mathrm{P}_{\mathrm{i}}$ incorporation, $\mathrm{Sf} .9$ cells expressing $5-\mathrm{HT}_{4(\mathrm{a})}$ receptor were incubated in the presence of varying concentrations of 5-HT. Levels of radiolabel incorporation were then quantified by autoradiographic analysis after immunoprecipitation of $5-\mathrm{HT}_{4(\mathrm{a})}$ receptors and SDS-PAGE. Figure 3.1B demonstrates that 5-HT induced a dose dependent increase in the phosphorylation intensity of the receptor with an $\mathrm{EC}_{50}$ of $180 \mathrm{nM}$. Kinetic analysis revealed a rapid 5-HT-induced increase in ${ }^{32} \mathrm{P}_{\mathrm{i}}$ incorporation into the $5-\mathrm{HT}_{4(\mathrm{a})}$ receptor $\left(\tau_{1 / 2} \approx 2 \mathrm{~min}\right.$ ), and maximal phosphorylation level was reached after $5 \mathrm{~min}$ (Figure 3.10). Phosphorylation of GPCRs may be controlled by multiple second messenger-activated protein kinases, including protein kinase C, PKA, and calcium/calmodulin-dependent kinase. We investigated whether these protein kinases may participate in phosphorylation of the 5- $\mathrm{HT}_{4(\mathrm{a})}$ receptor. Treatment of $\left[{ }^{32} \mathrm{P}_{\mathrm{i}}\right]$-labeled cells with forskolin, PMA, or with the $\mathrm{Ca}^{2+}$ ionophore A23187 to stimulate PKA, PKC CaMK kinase respectively, however, did not induce increased receptor phosphorylation (Figure 3.1A). Moreover, pretreatment of the receptorexpressing cells with the protein kinase inhibitor staurosporin at $1 \mu \mathrm{M}$ concentration did not reduce the agonist-promoted increase in 5- $\mathrm{HT}_{4(\mathrm{a})}$ receptor phosphorylation (Figure 3.1D). This concentration is known to block all second messenger protein kinases. These results demonstrate that the second messenger-dependent kinases tested do not mediate $5-\mathrm{HT}_{4(\mathrm{a})}$ receptor phosphorylation.

\subsubsection{Phosphorylation of palmitoylation-deficient $5-\mathrm{HT}_{4(\mathrm{a})}$ receptor mutants}

We have recently shown that $5-\mathrm{HT}_{4(\mathrm{a})}$ receptor undergoes agonist-dependent palmitoylation and also localized the palmitoylation sites by site-directed mutagenesis within 
the receptor C-terminal cytoplasmic domain (Ponimaskin et al. 2001, 2002b). Because the $5-\mathrm{HT}_{4(\mathrm{a})}$ receptor undergoes agonist-induced phosphorylation, we next analyzed a possible interplay between these two post-translational receptor modifications. Sf.9 insect cells expressing either the wild-type $5-\mathrm{HT}_{4(\mathrm{a})}$ receptor or its palmitoylation- deficient mutants were loaded with ${ }^{32} \mathrm{P}_{\mathrm{i}}$, stimulated with 5-HT, and then subjected to immunoprecipitation, SDSPAGE, and autoradiography. Immunoblot analysis revealed that all mutants were expressed at levels comparable with those of the 5- $\mathrm{HT}_{4(\mathrm{a})}$ wild-type control (Figure 3.2A), which allows for a quantitative comparison of phosphorylation levels in the different products. The

A

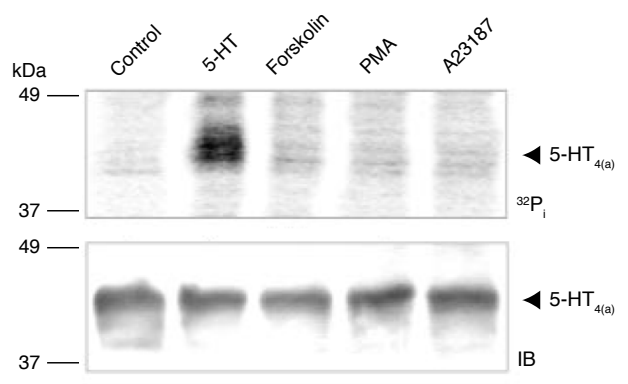

C

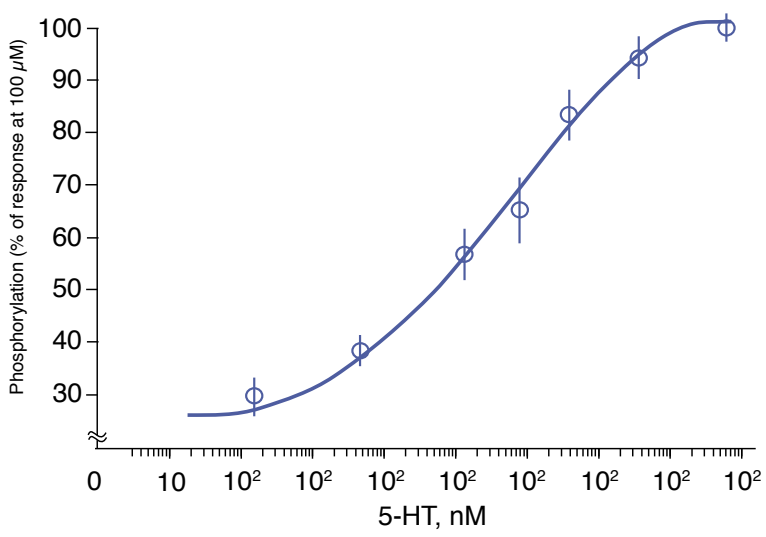

B

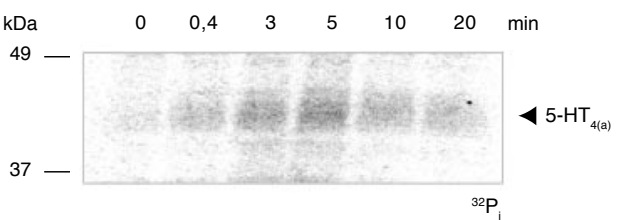

D

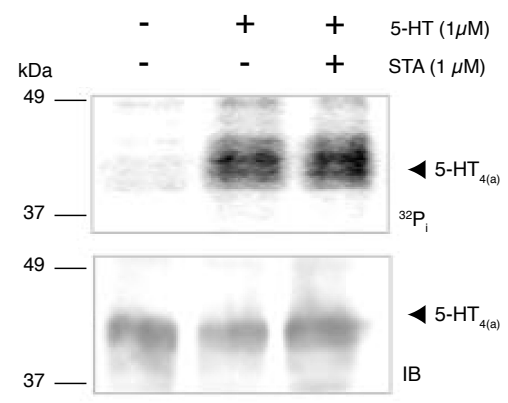

Figure 3.1 (A) 5- $\mathrm{HT}_{4(\mathrm{a})}$ receptor was expressed in Sf.9 insect cells, labeled with $\left[{ }^{32} \mathrm{P}_{\mathrm{i}}\right]$ phosphate and treated either with vehicle ( $\mathrm{H}_{2} \mathrm{O}$, control), $10 \mu \mathrm{M}$ 5-HT, $50 \mu \mathrm{M}$ forskolin, $200 \mathrm{nM}$ PMA, or $10 \mu \mathrm{M}$ A23187 for 10 $\mathrm{min}$. After immunoprecipitation with the antibody AS9459 directed against C-terminal domain of the 5- $\mathrm{HT}_{4(\mathrm{a})}$ receptor, samples were subjected to SDS-PAGE and autoradiography. Expression of the 5-HT ${ }_{4(\mathrm{a})}$ receptor was documented in parallel by immunoblot (IB). (B) [ $\left.{ }^{32} \mathrm{P}_{\mathrm{i}}\right]$-phosphate-labeled Sf.9 cells were treated with increasing concentrations of 5-HT for $10 \mathrm{~min}$. Receptors were immunoprecipitated, and ${ }^{32} \mathrm{P}_{\mathrm{i}}$ incorporation was calculated after SDS-PAGE and autoradiography. The values represent the means \pm S.E.M. $n=3$ (C) Phosphorylation kinetics were analyzed in Sf.9 cells expressing the 5- $\mathrm{HT}_{4(\mathrm{a})}$ receptor. After labeling with $\left[{ }^{32} \mathrm{P}_{\mathrm{j}}\right]$-phosphate, cells were treated with $10 \mu \mathrm{M} 5$-HT for the time interval shown and then subjected to immunoprecipitation, SDS-PAGE, and autoradiography. (D) Insect Sf.9 cells expressing recombinant 5- $\mathrm{HT}_{4(\mathrm{a})}$ receptor were labeled with $\left[{ }^{32} \mathrm{P}_{\mathrm{i}}\right]$-phosphate and incubated with $1 \mu \mathrm{m}$ of staurosporin for $20 \mathrm{~min}$ followed by stimulation with $10 \mu \mathrm{M}$ 5-HT for 10 min. Expression of the 5-HT ${ }_{4(a)}$ receptor was determined in parallel by immunoblot (IB). 
A
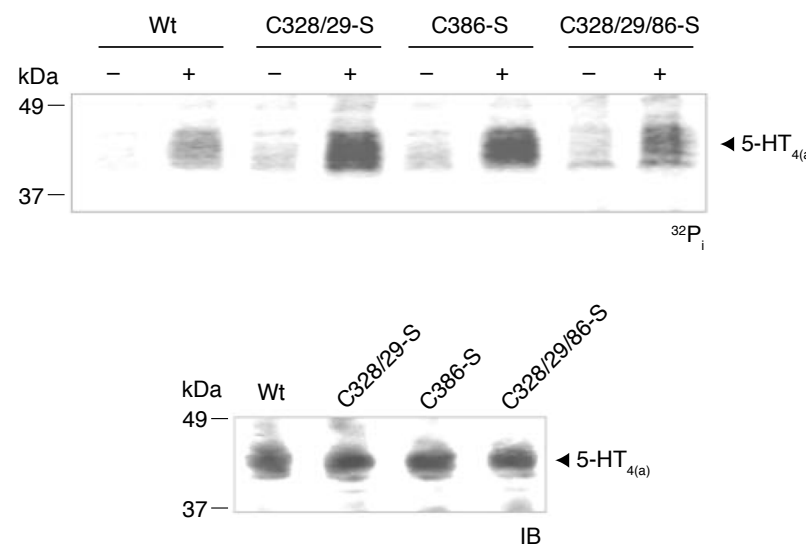

B

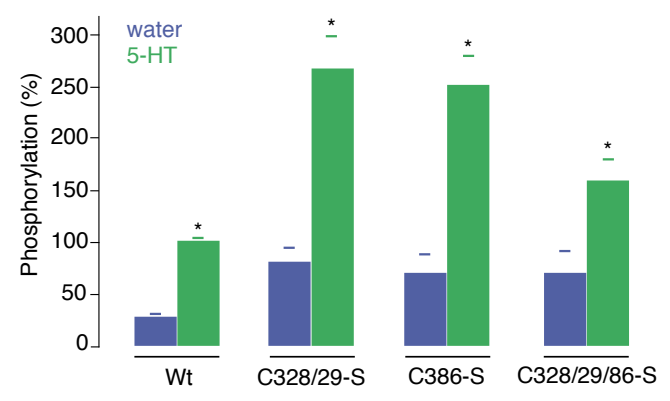

Figure 3.2 (A) Sf.9 cells expressing the 5- $\mathrm{HT}_{4(\mathrm{a})}$ receptor wild-type or its acylation-deficient mutants were incubated with either $\left[{ }^{32} \mathrm{P}_{\mathrm{i}}\right]$-phosphate in the presence of either vehicle $\left(\mathrm{H}_{2} \mathrm{O}\right.$, control) or $10 \mu \mathrm{M}$ 5-HT for 10 $\mathrm{min}$. Receptors were immunoprecipitated, resolved by SDS-PAGE and analyzed by autoradiography. Expression of the 5- $\mathrm{HT}_{4(\mathrm{a})}$ receptor was analyzed in parallel by immunoblot (IB). (B) Changes in receptor phosphorylation after 5-HT stimulation versus vehicle were determined by autoradiographic analysis in relation to receptor expression levels as determined by immunoblot. Results are shown as mean percentage \pm S.E.M. $(n=4)$. The value obtained for the receptor wild-type after 5 -HT stimulation was set at $100 \%$. A statistically significant difference between agonist-stimulated and nonstimulated phosphorylation is indicated $(*, p<0.01)$.

amount of $\left[{ }^{32} \mathrm{P}_{\mathrm{i}}\right]$-phosphate incorporated into each of these mutants was calculated by densitometry of fluorograms and normalized for expression levels of the various proteins as determined by immunoblotting. Analysis of the results obtained in ${ }^{32} \mathrm{P}_{\mathrm{i}}$ labeling experiments demonstrated that both basal and agonist-mediated phosphorylation efficiency for all acylation-deficient mutants was significantly elevated up to 2.7 fold compared with the wild-type receptor (Figure 3.2B). The increase in the phosphorylation efficiency over the basal level was particularly pronounced in the case of C328/29-S and C386-S receptor mutants.

\subsubsection{Phosphoamino acid analysis}

The C-terminal domain of the $5-\mathrm{HT}_{4(\mathrm{a})}$ receptor contains several serine and threonine residues that represent potential phosphate acceptor sites for G-protein receptor coupled GRK-mediated receptor phosphorylation. Therefore we defined which amino acids within the $5-\mathrm{HT}_{4(\mathrm{a})}$ receptor are modified by ligand-induced phosphorylation. We also analyzed 
whether different phosphorylation site(s) may be occupied in the acylation-deficient mutants. Phosphoamino acid analysis performed by 2D chromatography revealed that agonistmediated phosphorylation of the wild-type receptor as well as all acylation-deficient mutants occurs exclusively at serine residues (Figure 3.3).

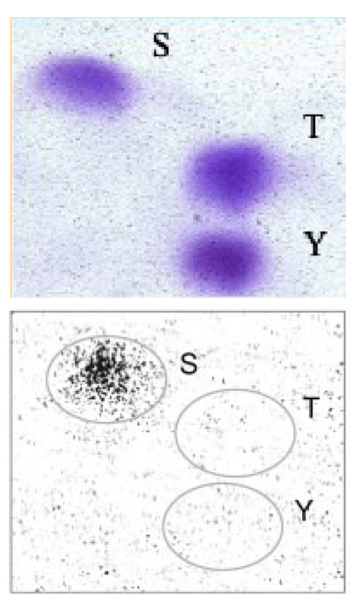

Wt

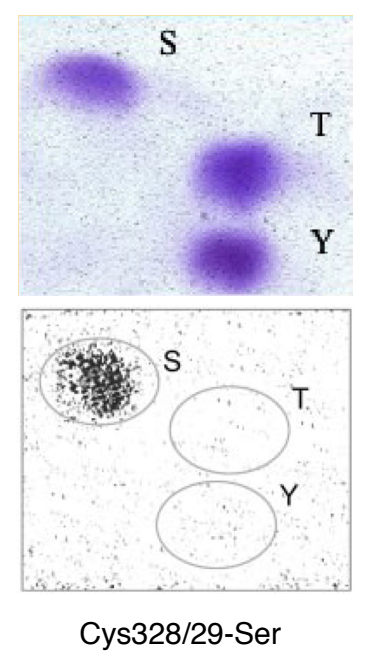

Cys328/29-Ser

Figure 3.3 Two-dimensional phosphoamino acid analysis of the 5-HT $\mathrm{H}_{4(\mathrm{a})}$ receptor, Sf.9 insect cells expressing the 5- $\mathrm{HT}_{4(\mathrm{a})}$ receptor wild-type or Cys328/329-Ser mutant were labeled with $\left[{ }^{32} \mathrm{P}_{\mathrm{i}}\right]$-phosphate in the presence of $10 \mu \mathrm{M}$ 5-HT. Phosphoamino acid analysis of the immunoprecipitated and hydrolized receptors was performed. Positions of phosphoserine (S), phosphothreonine (T), and phosphotyrosine (Y) were determined by ninhydrin staining of phosphoamino acid standards, which were separated together with radioactive samples. ${ }^{32} \mathrm{P}_{\mathrm{i}}$ signal was located only in the area of the phosphoserine residues in both cases.

\subsection{3 $\beta$-arrestin2 mediated desensitization and internalization of the $5-\mathrm{HT}_{4(\mathrm{a})}$ receptor}

To further assess the role of palmitoylation for the agonist-induced 5-HT ${ }_{4(\mathrm{a})}$ receptor desensitization, the effects of sustained agonist treatment on the signaling efficacy of the Wt and acylation-deficient mutants were compared in COS-7 cells. Receptor activities were measured in transfected cells that were pretreated with or without 5-HT for different periods. Desensitization was then defined as the reduction in the efficiency of agonist to stimulate adenylate cyclase activity after agonist pretreatment. As illustrated in igure 3.4A, the onset of agonist-promoted desensitization was accelerated for all acylation-deficient mutants and particularly for the C328/29-S construct, compared with wild-type. However, the rate of desensitization was relatively low; after 1 hour of preincubation, we found that the residual response to the agonist was $80 \pm 8 \%, 72 \pm 6 \%, 68 \pm 9 \%$, and $62 \pm 7 \%$ for the Wt, C386-S, C328/29/86-S, and C328/29-S, respectively. Even at the longest desensitization time studied, we could still detect residual adenylate cyclase activity of $62 \pm 6 \%, 50 \pm 5 \%, 45 \pm 8 \%$ and $33 \pm 7 \%$ for the Wt, C386-S, C328/29/86-S, and C328/29-S, respectively (Figure 3.4B). This 
is in contrast to previous observations in rat esophagus and colliculus neurons of mouse, where exposure of cells to selective $5-\mathrm{HT}_{4(\mathrm{a})}$ receptor agonists was accompanied by a very potent and rapid desensitization of the receptor-stimulated adenylate cyclase response. Such divergent findings may either indicate cell type specific effects based on a differential expression of regulatory proteins or may result from overexpression of receptors in transfected cell lines.

Taken together, our results indicate that the acylation-deficient mutants were more sensitive to agonist pre-exposure than the receptor wild-type. The rate of agonist-promoted receptor desensitization was greatest for the proximal acylation mutant C328/29-S. This suggests that, in agreement with our findings with receptor phosphorylation, desensitization of the $5-\mathrm{HT}_{4(\mathrm{a})}$ receptor may also be regulated by its palmitoylation state (Ponimaskin et al. 2005) (Desensitization experiments were done in collaboration with Dr. A Dumuis).
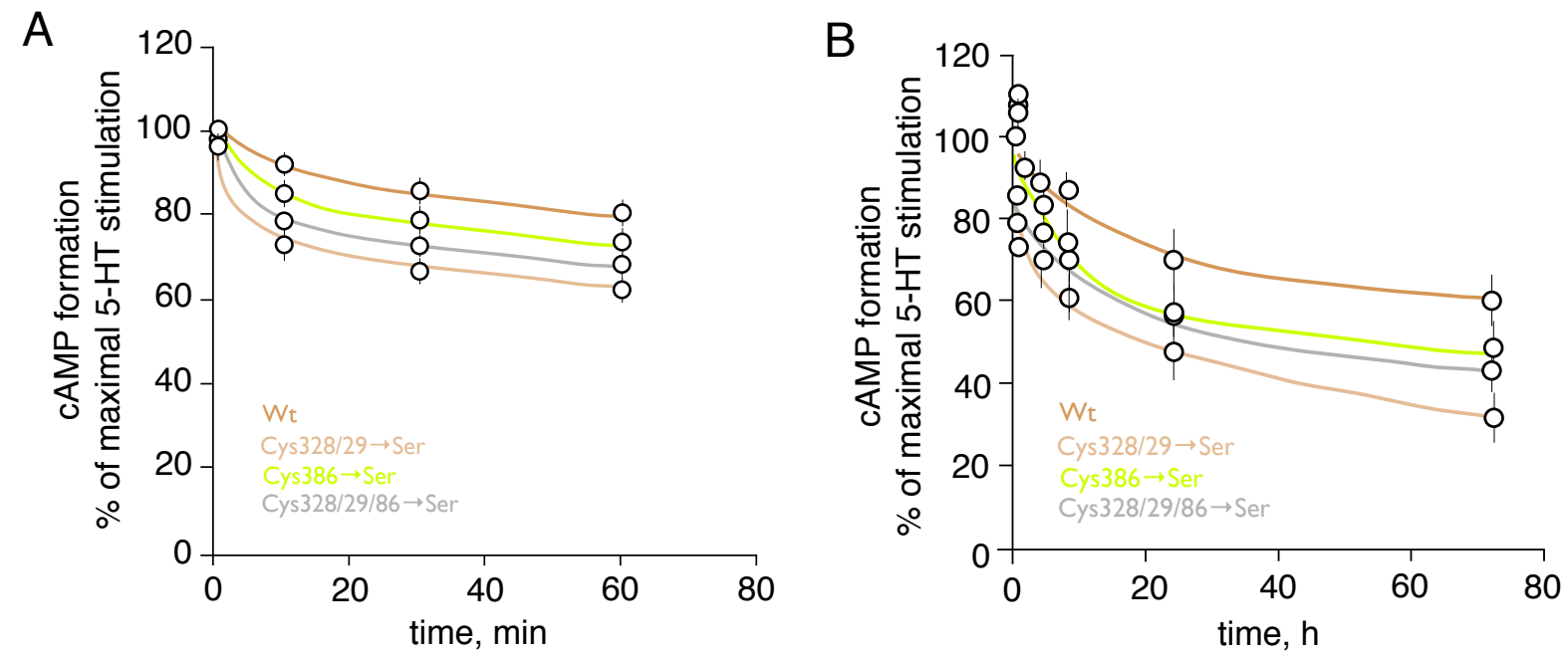

Figure 3.4 Time course of desensitization of the 5- $\mathrm{HT}_{4(\mathrm{a})}$ receptor wild-type and palmitoylation deficient mutants. COS-7 cells expressing either the wild-type (wt) or acylation-deficient mutants were preincubated with $1 \mu \mathrm{M}$ 5-HT for a short (0-60 min) (A) or for a long (0-18 h) (B) period of time. After extensive washes with the medium, cAMP accumulation was measured. Results are expressed as a percentage of residual stimulation relative to the maximal stimulation obtained for the particular receptor. Each value represents the means \pm S.E.M. from at least three independent experiments performed in triplicate. Statistically significant differences between receptor wild-type and Cys328/329 $\rightarrow$ Ser mutant after $1 \mathrm{~h}$ and $18 \mathrm{~h}$ are indicated.

\subsubsection{Role of G-protein receptor kinase in desensitization of the $5-\mathrm{HT}_{4(\mathrm{a})}$ receptor}

Phosphorylation of the 5- $\mathrm{HT}_{4(\mathrm{a})}$ receptor is not affected by stimulation of several different second messenger-activated protein kinases (Figure 3.1A,D). In addition, it has been demonstrated that the functional desensitization of the $5-\mathrm{HT}_{4}$ receptors in mouse colliculus neurons is cAMP-independent and agonist-selective. This suggests a possible role of GRKs in the 
desensitization process. To test this hypothesis, we co-expressed GRK2 with the wild-type and different $5-\mathrm{HT}_{4(\mathrm{a})}$ receptor mutants and determined the amount of cAMP accumulation over a 10-min incubation period. In this experimental setting, "desensitization" is interpreted as the cumulative effect of GRK overexpression on 5-HT-induced cAMP generation compared with cells with endogenous GRK levels. As shown in Figure 3.5, the basal activity of cells co-expressing the different receptors together with GRK2 was not significantly changed. In contrast, the agonist-induced cyclase response was significantly $(p<0.01) \mathrm{im}$ paired in cells overexpressing GRK2 compared with the control (Figure 3.5). After a 10-min stimulation period with 5-HT, the maximal stimulation of adenylate cyclase in cells overexpressing GRK2 was reduced to $28 \pm 8 \%, 35 \pm 5 \%, 55 \pm 11 \%$, and $51 \pm 9 \%$ of control cells (without coexpression of GRK2) for the wild-type, C328/29-S, C86-S, and C328/29/86-S, respectively. A 60 min-agonist pre-exposure performed before the period of cAMP accumulation did not significantly decrease the 5-HT response (data not shown). Taken together, these re-

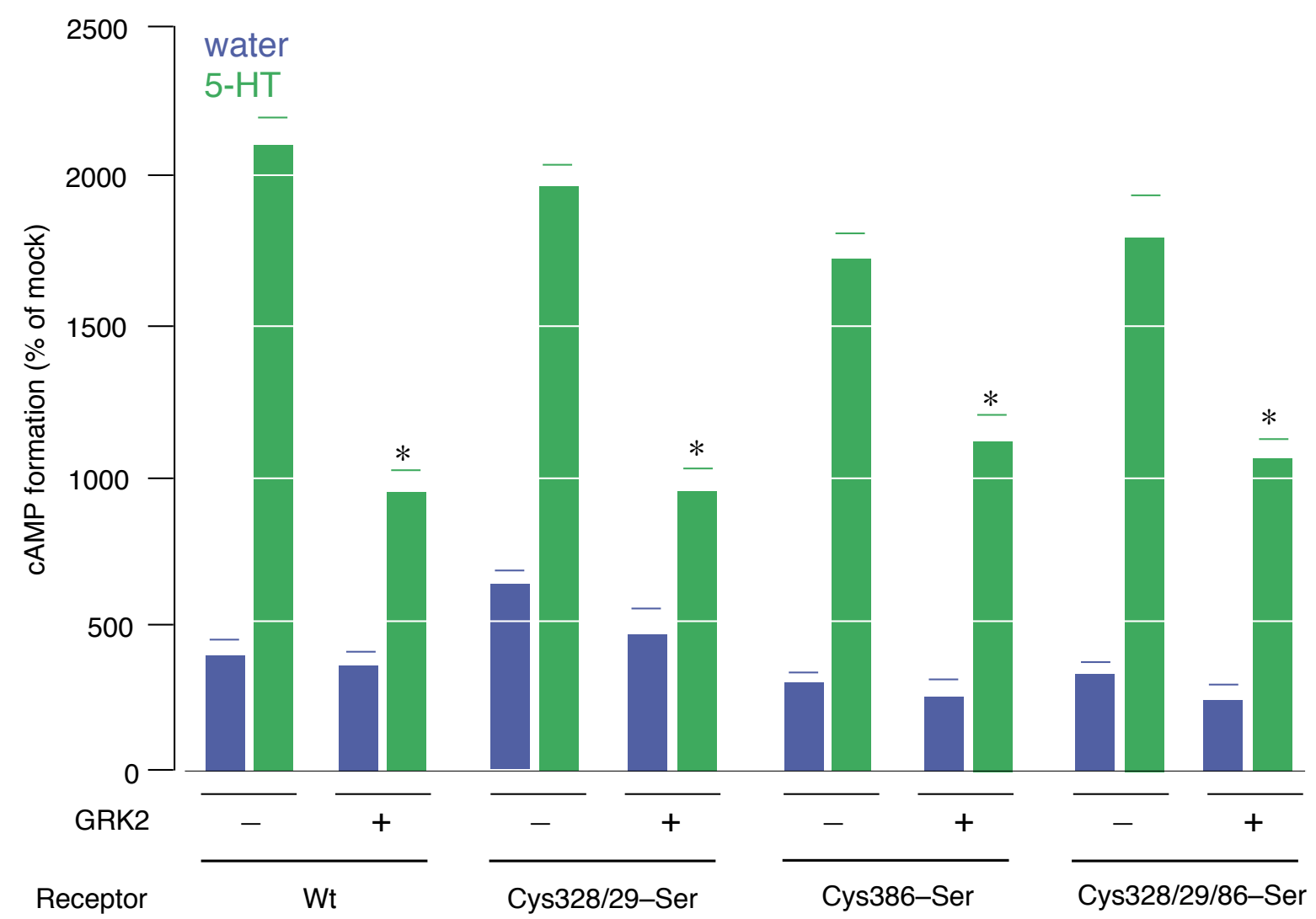

Figure 3.5 Desensitization of the 5- $\mathrm{HT}_{4(\mathrm{a})}$ receptors after overexpression of GRK2. COS-7 cells expressing either the $5-\mathrm{HT}_{4(\mathrm{a})}$ Wt receptor or acylation-deficient mutants were cotransfected with or without the vector encoding GRK2 (500 ng/107 cells). The 5-HT (10 $\mu \mathrm{M})$ induced cAMP production was directly measured during $10 \mathrm{~min}$. Results are expressed as a percentage of the cAMP production in mock-transfected cells. In mock-transfected cells, $0,15 \pm 0,02 \%$ of $\left[{ }^{3} \mathrm{H}\right]$-ATP was converted into $\left[{ }^{3} \mathrm{H}\right]$-cAMP. The values are plotted as the percentage conversion of $\left[{ }^{3} \mathrm{H}\right]$-ATP into $\left[{ }^{3} \mathrm{H}\right]$-cAMP. Each value represents the means \pm S.E.M. $n=3$. A statistically significant difference between the values is indicated $\left({ }^{*}, \mathrm{p}<0.01\right)$. 
sults strongly suggest a role for GRK2 (or a related receptor kinase) in homologous desensitization of the $5-\mathrm{HT}_{4(\mathrm{a})}$ receptor.

\subsubsection{Role of palmitoylation in agonist-induced internalization of the 5-HT 4(a) $_{\text {receptor }}$}

In many GPCRs, GRK induced receptor phosphorylation plays an important role in facilitating $\beta$-arrestin-mediated receptor internalization. To analyze whether the $5-\mathrm{HT}_{4(\mathrm{a})}$ receptor undergoes agonist dependent internalization, the COS-7 cells were transiently cotransfected with $5-\mathrm{HT}_{4(\mathrm{a})}-$ YFP receptor and $\beta$-arrestin2-GFP2. Functionality of receptor-YFP construct was confirmed by ligand binding, 5-HT induced adenylate cyclase activity, and serum response element assay. Distribution of the receptor and $\beta$-arrestin 2 was then analyzed by confocal microscopy on LSM510-Meta microscope. Without agonist stimulation, the 5-HT 4 (a) receptor was mainly localized at the plasma membrane, whereas $\beta$-arrestin 2 showed homogeneous cytoplasmic staining (Figure 3.6A). Treatment of transfected cells with $1 \mu \mathrm{M}$ 5-HT for $60 \mathrm{~min}$ induced clear receptor internalization with punctate, clustered 5- $\mathrm{HT}_{4(\mathrm{a})}$ receptor-YFP structures that were partially colocalized with $\beta$-arrestin2 (Figure 3.6A). Having established that phosphorylation efficiency of the $5-\mathrm{HT}_{4(\mathrm{a})}$ receptor is modulated by receptor palmitoylation, we next compared the rate of agonist-mediated internalization for acylationdeficient mutants. In addition, we analyzed whether arrestin might modulate this process. COS-7 cells were transiently transfected with plasmids encoding the wild-type or mutated receptors in the presence or absence of $\beta$-arrestin 2 overexpression. Binding of the receptorspecific antagonist [ $\left.{ }^{3} \mathrm{H}\right]$-GR113808 on intact cells was used to quantify the number of receptors at the cell surface. This assay revealed that the wild-type and all palmitoylation-deficient mutants showed similar expression levels at the cell surface under basal conditions. Cells were then treated with the agonist, and internalization was measured up to 60 minutes after agonist exposure. As shown in the Figure 3.6B, in the absence of recombinant $\beta$-arrestin 2 overexpression, the wild-type and all acylation-deficient mutants underwent slow agonist-mediated internalization. We found that after 60 minutes of incubation with 5-HT, approximately $25 \%$ of the wild-type, C386-S, and C328/29/86-S mutants were internalized, whereas internalization of the proximal mutant C328/29-S was more efficient; approximately $35 \%$ of this mutant were removed from the cell surface (Figure 3.6). Co-expression of the $5-\mathrm{HT}_{4(\mathrm{a})}$ receptor wild-type with $\beta$-arrestin 2 resulted only in moderate enhancement of internalization up to 30\% (Figure 3.6C). In the case of the C386-S and C328/29/86-S mutants, the rate of agonist-induced internalization upon coexpression with $\beta$-arrestin 2 was increased up to $45 \%$ (Figure 3.6C). The effect of $\beta$-arrestin 2 overexpression was strongest in the $\mathrm{C} 328 / 29-\mathrm{S}$ mutant, where $77 \%$ of ligand binding sites were removed from the cell surface after 60-min incubation with 5-HT (Figure 3.6D). The different effects of $\beta$-arrestin2 overexpression on internalization of the receptor variants were found not to be caused by different $\beta$-arrestin 2 expression levels in the various transfections. The fact that the highest 

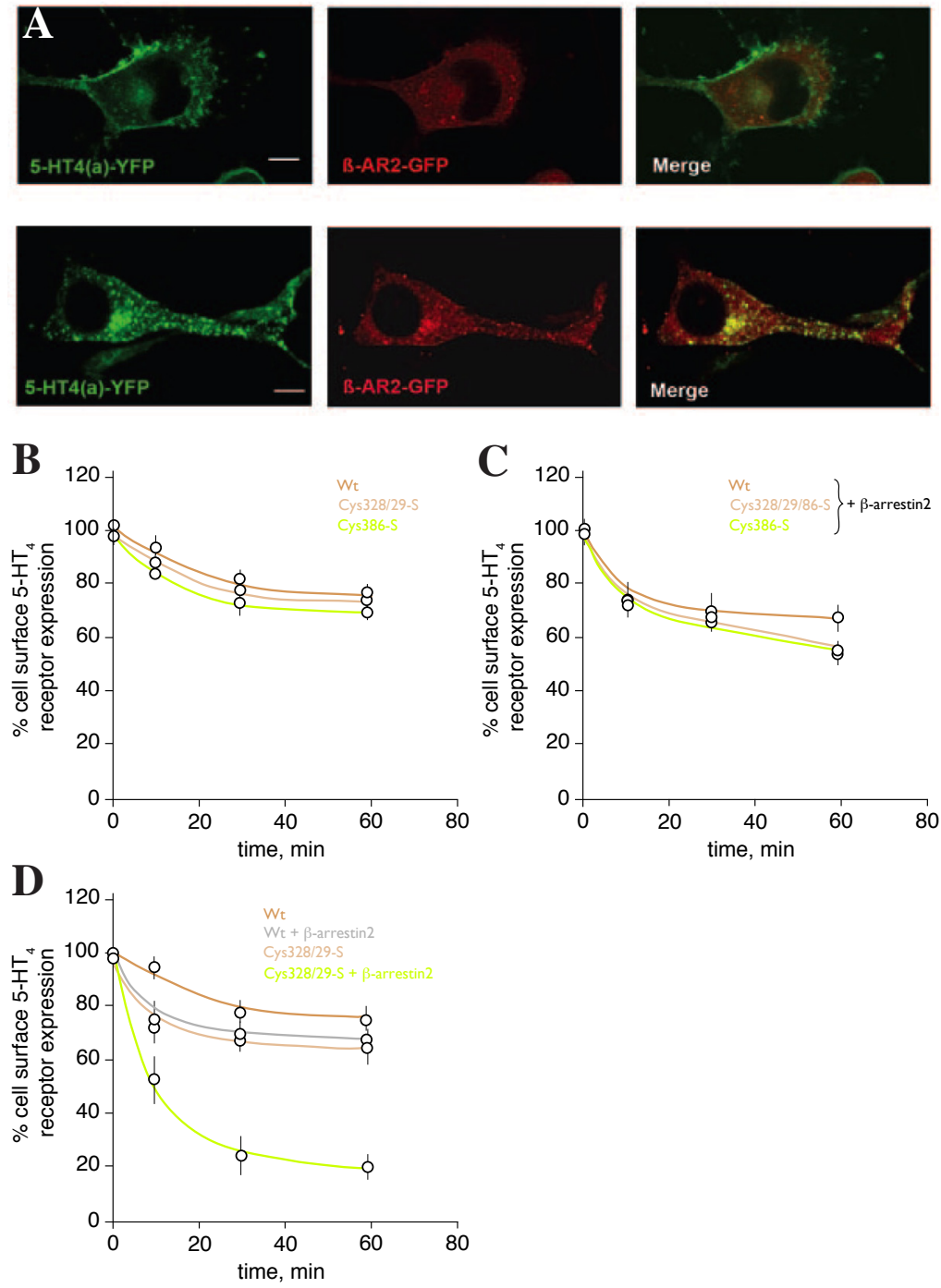

Figure 3.6 (A) Internalization of the 5- $\mathrm{HT}_{4(\mathrm{a})}$ receptor and effect of $\beta$-arrestin2 overexpression. COS-7 cells expressing YFP-tagged 5- $\mathrm{HT}_{4(\mathrm{a})}$ receptor and $\mathrm{GFP}^{2}$-tagged $\beta$-arrestin2 were incubated for 1 hour with (lower panel) or without (upper panel) $1 \mu \mathrm{M}$ 5-HT followed by fixation and microscopic analysis. Scale bar $-10 \mu \mathrm{M}$. (B-D) COS-7 cells were transiently transfected with vectors encoding WT or acylation-deficient mutants as indicated. The cells were stimulated with $1 \mu \mathrm{M} 5-\mathrm{HT}$ at $37^{\circ} \mathrm{C}$ and extensively washed. Sequestration of antagonist $\left[{ }^{3} \mathrm{H}\right]$-GR113808 from the cell surface was measured. Kinetics of internalization for the WT and indicated acylation-deficient mutants in the absence $(\mathbf{B})$ or presence $(\mathbf{C})$ of $\beta$-arrestin2 overexpression are shown. (D) comparison of internalization kinetics for the $\mathrm{Wt}$ and C328/29-S mutant in the presence and absence of $\beta$-arrestin2 overexpression. Data represent the means \pm S.E.M. from five independent experiments performed in duplicate. A statistically significant difference between the values for the Wt and C328/29-S mutant in the presence of $\beta$-arrestin 2 overexpression is indicated $\left({ }^{*}, \mathrm{p}<0.01\right)$. Each value represents the means \pm S.E.M., $\mathrm{n}=3$.

rate of receptor endocytosis was obtained for the mutant C328/29-S suggests that the lack of palmitoylation at these sites renders $5-\mathrm{HT}_{4(\mathrm{a})}$ receptors more susceptible to $\beta$-arrestin2-mediated internalization, and this effect becomes more apparent under experimental conditions of $\beta$-arrestin2 overexpression. 


\subsubsection{BRET $^{2}$ analysis of $\beta$-arrestin2 mediated desensitization of 5-HT 4 (a) receptor}

\subsection{Generation, expression and functional properties of the 5-HT (a) $-\mathrm{Rluc}$ constructs}

To study the impact of the palmitoylation on the 5-HT 4 (a) receptor desensitization by BRET ${ }^{2}$ assay. $5-\mathrm{HT}_{4(\mathrm{a})}$-Rluc fusion constructs were generated by PCR using primers

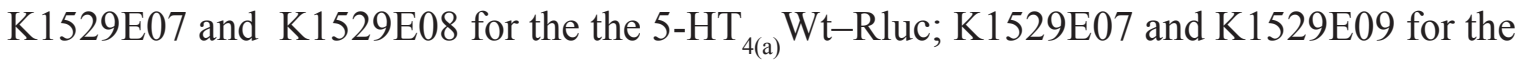

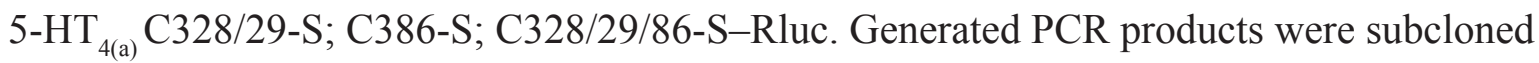
into pRluc-N2 vector, and sequenced with $\mathrm{K} 4875 \mathrm{G} 06$ primer to check the presence of the mutated cysteine residues and K4875G05 to ensure the correct reading frame. Attachment of the Renilla luciferase $(36 \mathrm{kDa})$ to the $5-\mathrm{HT}_{4(\mathrm{a})}$ receptor will cause an increase in molecular weight of the receptor from $43 \mathrm{kDa}$ to $79 \mathrm{kDa}$. Immunoblot analysis made from transfected HEK 293 cells discovered a single protein band with a predicted molecular weight of approximately $76 \mathrm{kDa}$ for the wild-type and all mutants. Transfected cells were also subjected to immunofluorescence microscopy with anti-Renilla luciferase antibodies (Figure 3.7 C). Analyzis of subcellular distribution performed by confocal microscopy after immunocytochemistry revealed that the major fraction of the receptors fused to Rluc possesses the similar intracellular distribution as its non-fused counterpart.

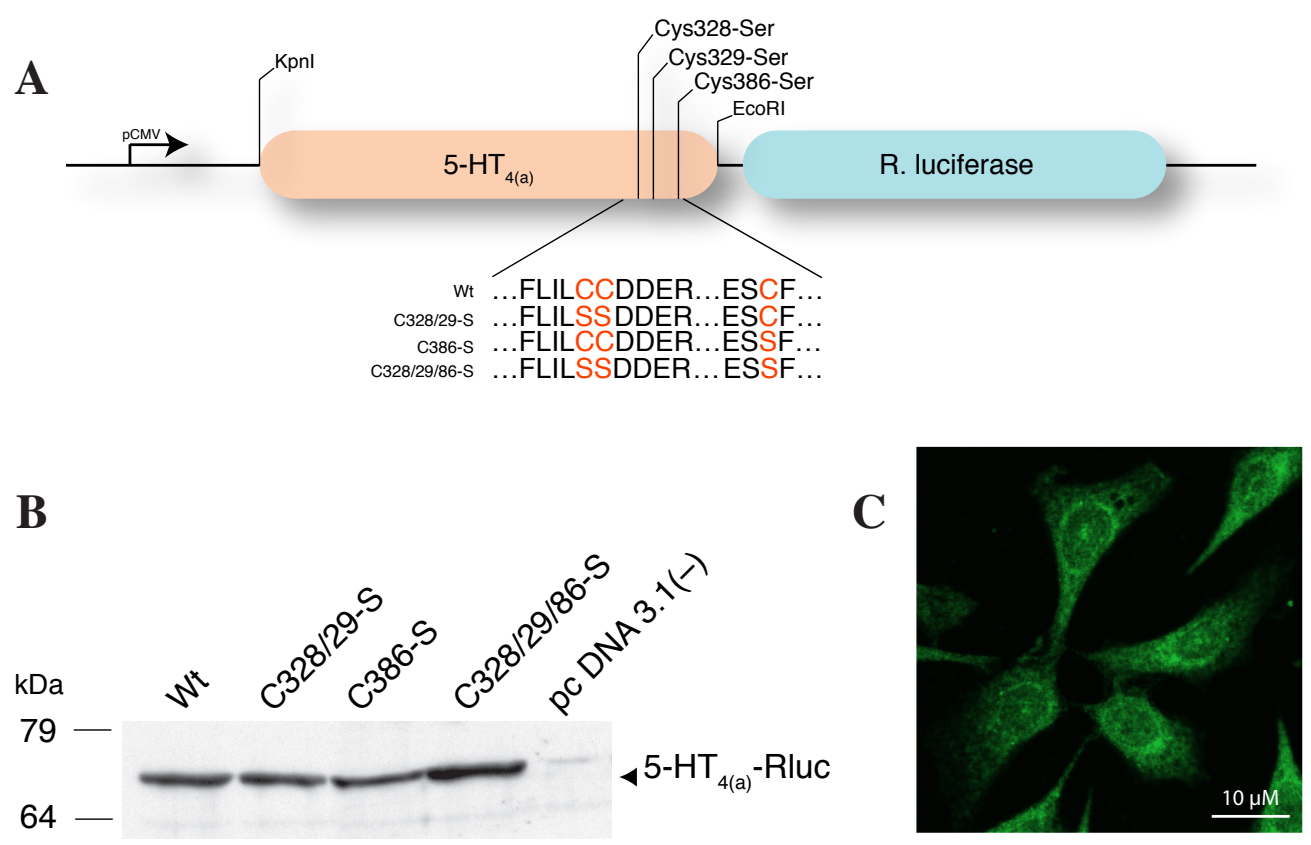

Figure 3.7 (A) Schematic presentation of 5- $\mathrm{HT}_{4(\mathrm{a})}-\mathrm{Rluc}$ constructs. The part of C-terminal sequences including mutated cysteins shown using single letter code. (B) HEK 293 cells were transfected with 5-HT 4 (a) - Rluc plasmids. Immunobloting revealed a band with molecular weight around 72kDa. (C) HEK 293 cells were transfected with the 5- $\mathrm{HT}_{4(\mathrm{a})} \mathrm{Wt}-\mathrm{Rluc}$, and its intracellular distribution was analyzed by confocal microscopy after treatments with TX-100 and immunostaining with anti-Rluc AB. 


\subsection{Pharmacological properties of 5-HT $4(a)$-Rluc constructs}

To confirm that attachment of Renilla luciferase does not affect pharmacological properties of the receptor. Receptor-Rluc constructs were subjected to a pharmacological analysis with a specific antagonist of the $5-\mathrm{HT}_{4(\mathrm{a})}$ receptor $-\left[{ }^{3} \mathrm{H}\right]$-GR113808. The binding affinities of $\left[{ }^{3} \mathrm{H}\right]-\mathrm{GR} 113808$ for all 5-HT $\mathrm{H}_{4(\mathrm{a})}-$ Rluc constructs were similar to that observed for the non-labled receptor. These values are also in accordance with previous data, demonstrating that the YFP fusion does not change the pharmacological properties of the wild-type $5-\mathrm{HT}_{4(\mathrm{a})}$ receptor. In addition, binding affinity obtained for all acylation-deficient mutants fused to luciferase and was similar to results published before (Ponimaskin et al. 2002) (Figure 3.8).

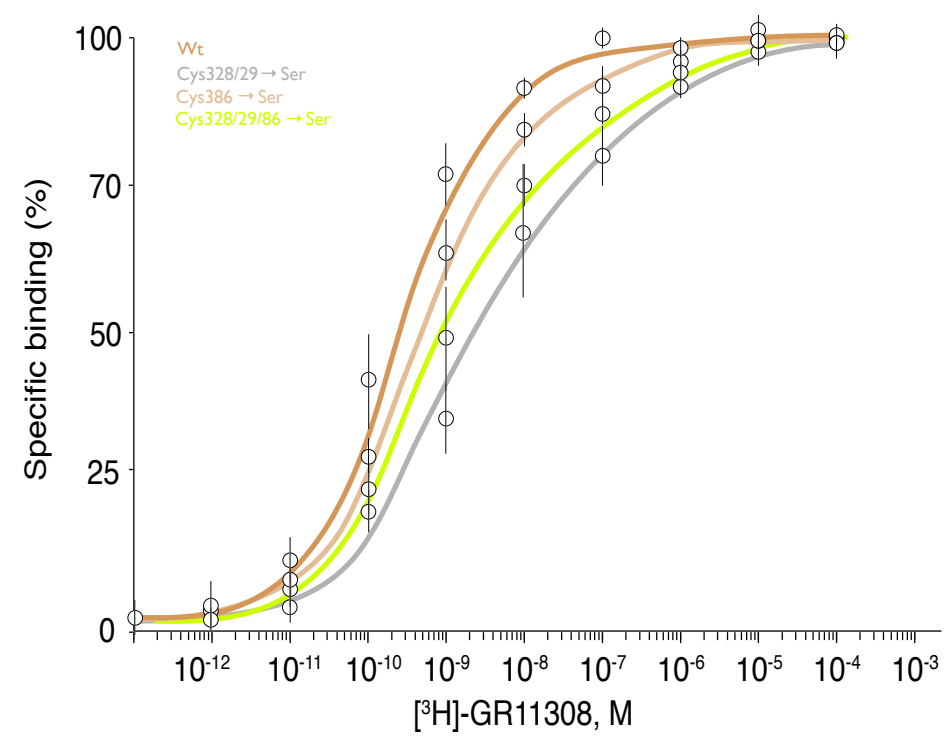

Figure 3.8 Pharmacological properties of the chimeric receptors, HEK 293 cells were transfected with different variants of the $5-\mathrm{HT}_{4(\mathrm{a})}-\mathrm{Rluc}$ plasmid and binding properties were analyzed with a specific antagonist of the $5-\mathrm{HT}_{4(\mathrm{a})}$ receptor $-\left[{ }^{3} \mathrm{H}\right]-\mathrm{GR} 113808$. Each value represents the mean \pm S.E. $\mathrm{n}=3$.

\subsection{Analysis of receptor expression level by using Renilla luciferase}

\section{luminescence}

To exclude the problem of variation in expression level from trial to trial, we performed a normalization assay, where we normalized BRET ${ }^{2}$ data to the level of 5-HT 4 (a) Rluc receptor expression. Standard technique to measure receptor expression level in different experiments is a radioligand-binding assay. But it is difficult to perform this assay in parallel with BRET $^{2}$ experiment. In addition this experiments need a radioactive substances and are very time consuming. Therefore we examine wether data obtained by radioligand-binding assay may correlate with the measurement of the luciferase luminescence. To establish 


\begin{tabular}{|c|c|c|c|c|}
\hline & $\mathrm{Wt}$ & $\mathrm{C} 328 / 29-\mathrm{S}$ & $\mathrm{C} 386-\mathrm{S}$ & $\mathrm{C} 328 / 29 / 86-\mathrm{S}$ \\
\hline $\mathrm{K}_{\mathrm{D}}\left(\mathbf{x 1 0 ^ { - 9 } \mathrm { M } )}\right.$ & $0,25 \pm 0,05$ & $0,84 \pm 0,11$ & $0,33 \pm 0,09$ & $0,40 \pm 0,04$ \\
\hline
\end{tabular}

Table 1. Binding of the $\left[{ }^{3} \mathrm{H}\right]$-GR113808 to the Rluc-tagged 5-HT ${ }_{4(\mathrm{a})}$ receptor wild-type and acylation deficient mutants. Binding was perform in HEK 293 cells transiently expressing different forms of the 5-HT 4 (a) receptor. $\mathrm{K}_{\mathrm{D}}$ values calculated from three independent experiments and each value represents the mean \pm S.E. $n=3$. Data were analyzed by GraphPad Prism software.

this new assay we transfected HEK 293 cells with 5-HT $\mathrm{H}_{4(\mathrm{a})}-\mathrm{Rluc}$ construct and analyzed the expression of the receptor by measuring luminescence after addition of the Colenterazine $\mathrm{H}$ substrate. In parallel, the radioligand-binding assay was done. Figure 3.9 shows that there is a linear dependence between expression level of the receptor-luciferase fusion protein as assessed by radiligand binding and luminescence. It is noteworthy that using Coelenterazine $\mathrm{H}$ as substrate; does not promote energy transfer to $\mathrm{GFP}^{2}$. Analysis of receptor expression by using Coelenterazine $\mathrm{H}$ luminescence was then applied in every BRET experiment and to the some expression level.

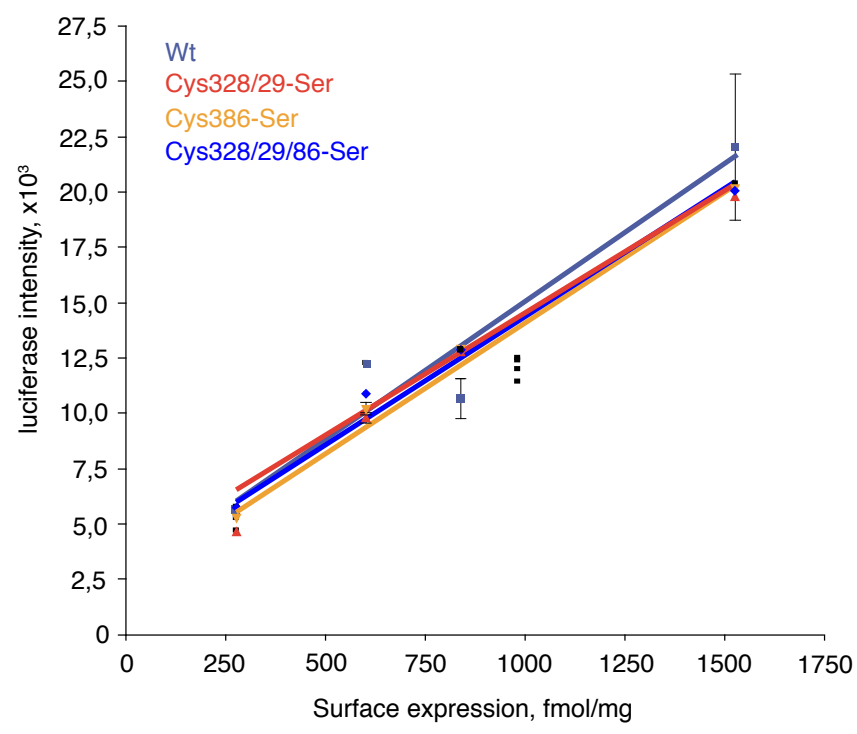

Figure 3.9 To normalize $\mathrm{BRET}^{2}$ data to the expression level of the 5-HT $\mathrm{H}_{4 \mathrm{a})}-\mathrm{Rluc}$, luminescence level of the Renilla luciferase was correlated to the amount of the receptor on the cell surface (in range from 250 to $1500 \mathrm{fmol} / \mathrm{mg}$ ), which was measured by ligand binding. Linear dependence between the luminescence and the amount of the receptor was noted. Each value represents the mean \pm S.E. $n=3$.

\subsection{Establishing of the BRET $T^{2}$ assay}

To study direct interaction between $\beta$-arrestin 2 and $5-\mathrm{HT}_{4(\mathrm{a})}$ receptor, we utilized Bioluminescent Resonance Energy Transfer $\left(\mathrm{BRET}^{2}\right)$ assay. This approach is based on Förster energy transfer between Renilla reniformis' luciferase and $\mathrm{GFP}^{2}$. It is similar to 
FRET principle, but does not have some disadvantages of the last one. In BRET there is no need of an external source of illumination to excite the donor, because this is promoted by enzymatic oxidation of the cell-permeable substrate. This drastically reduces background noise during $\mathrm{BRET}^{2}$ measurements. In addition no spectral overlaping of emissions spectras. To establish this assay, we performed control experiments, where HEK 293 cells were transfected with a vector coding fusion protein between Renilla luciferase and GFP ${ }^{2}$ BRET $^{2}$ controls) or co-transfected with Renilla luciferase and GFP2 coding plasmids (Figure 3.10). BRET efficiency of the fusion protein was close to 1, and both negative controls showed extremely low values around $0,03 \pm 0,005$. This result demonstrated high reproducibility of BRET signal and that $\mathrm{BRET}^{2}$ assay characterized by a very good signal to noise ratio.

\subsection{Dose dependence of receptor- $\beta$-arrestin 2 interaction by BRET assay}

To analyze interaction between 5- $\mathrm{HT}_{4}$ receptor and $\beta$-arrestin2 in living cells, we measured BRET response in HEK 293 cells, co-expressing receptor-luciferase and $\beta$-arrestin2-GFP ${ }^{2}$ constructs. For that, cells were treated with serotonin in range from $10^{-9} \mathrm{M}$ to $10^{-5}$ $\mathrm{M}$ (Figure 3.11). Concentration of $10 \mu \mathrm{M}$ of 5-HT was chosen for further experiments, since at this concentration increase in BRET ratio was maximal for wild-type and C328/29-S receptors (around 30\%). We also applied frequency distribution analysis to study the specificity of increase of the BRET ${ }^{2}$ signal after application of serotonin (Figure 3.12). This analysis revealed a shift to the right (higher $\mathrm{BRET}^{2}$ values) after agonist application indicating receptor- $\beta$-arrestin 2 interaction.

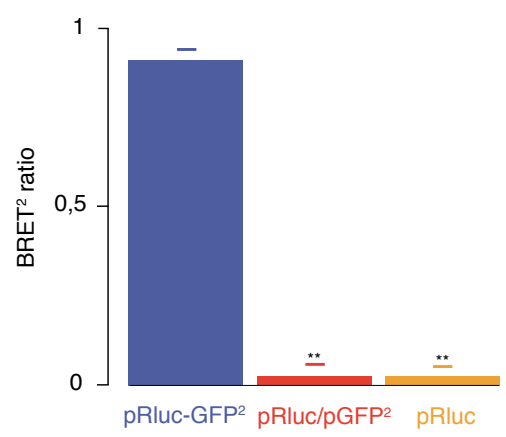

Figure 3.10 $\mathrm{BRET}^{2}$ control experiments. HEK 293 cells were transfected either with the pRluc-GFP² fusion construct, with Rluc alone or co-transfected with Rluc and $\mathrm{GFP}^{2}$ as negative controls. Rluc-GFP ${ }^{2}$ plasmid caused more that 30 fold increase in BRET ratio in comparison with negative controls. A statistically significant difference between the values is indicated $(* *, p>0.01)$. Each value represents the mean \pm S.E. $n=3$. 


\subsection{Time course analysis of 5-HT $4(a)$ and $\beta$-arrestin2 interaction}

The general sequence of the events involved in receptor desensitization is well understood. However, since many biochemical assays only allow measuring responses only within minutes and even hours, it is still unknown what is happen immediately after receptor activation. To analyze receptor- $\beta$-arrestin 2 interaction with millisecond resolution we applied modification of the BRET ${ }^{2}$ assay published by Bouvier's group (Gales et al. 2005). This assay time resolved analysis by measuring of BRET every 50 miliseconds (Figure 3.13A). For data fitting we applied equation 1 (Figure 3.13B) (Charest and Bouvier 2003). From this analysis half speed of the $\beta$-arrestin 2 recruitment to the receptor $\left(\tau_{1 / 2}\right)$ was calculated for the wild-type and mutants (Table 2).

All three mutants demonstrated a higher level of interaction prior to stimulation with BRET values of $0.145 \pm 0.004,0.142 \pm 0.003,0.140 \pm 0.002$ for C328/29-S, C386-S and C328/29/86-S respectively. in comparison with the wild-type $0.130 \pm 0.003$ (Figure 3.15). However, maximal BRET ratios obtained upon stimulation for the acylation mutant $0.198 \pm 0.001,0.194 \pm 0.001,0.193 \pm 0.001$, C328/29-S, C386-S and C328/29/86-S respectively, did not reach $0.207 \pm 0.001$ values for the wild-type (Figure 3.15). This means that maximal increase in interaction was obtained for the wild-type (1.59 fold) while this values for acylation-deficient mutants was reduced to 1.36 . Interaction kinetic was also different. For

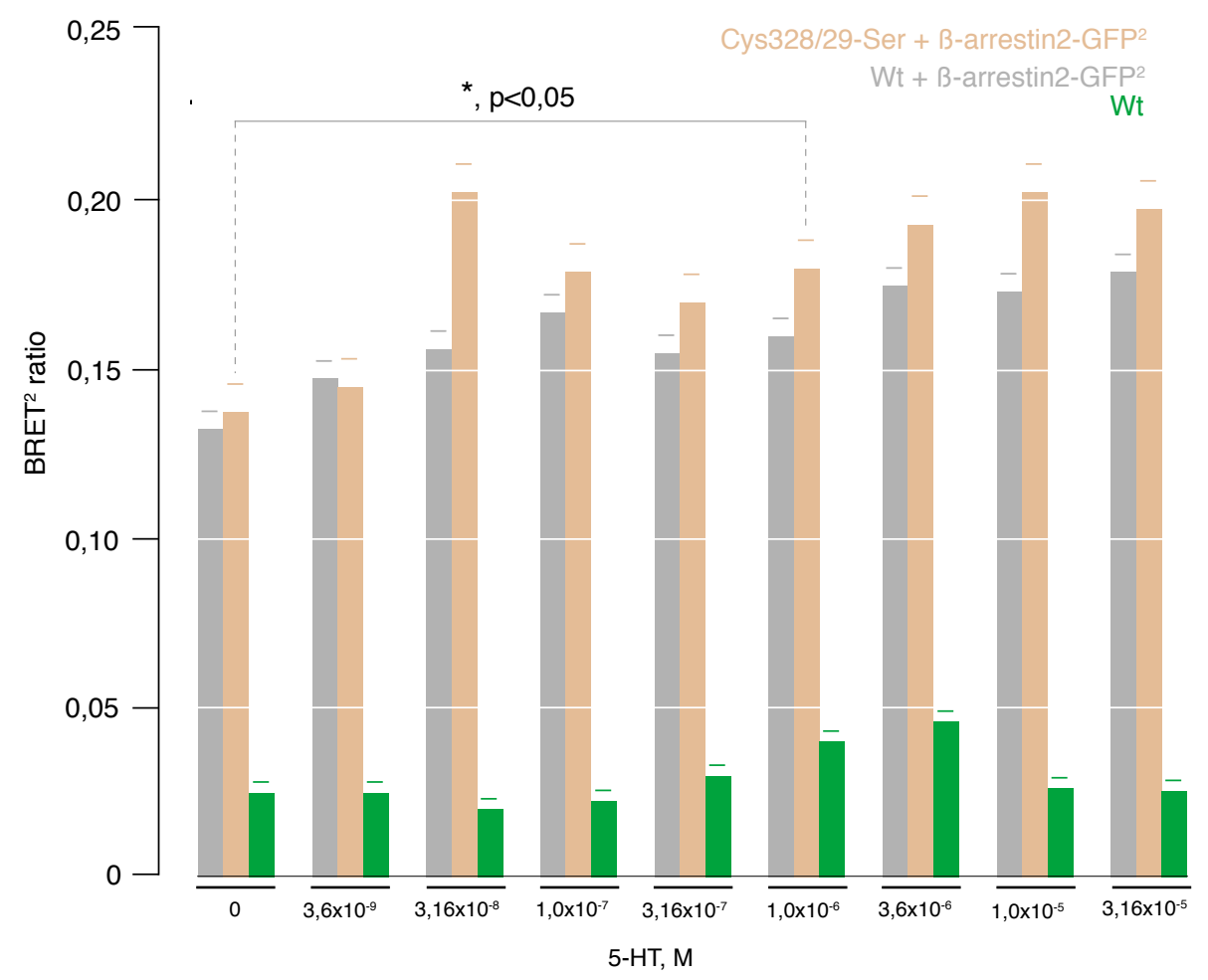

Figure 3.11 HEK 293 cells solely expressing wild-type or co-expressing 5-HT4(a)-Rluc wild-type or Cys328/29-Ser and $\beta$-arrestin2-GFP2 constructs were treated with increasing concentrations (0 M to 3,16x10${ }^{5} \mathrm{M}$ ) of 5-HT for 60 seconds, then BRET measurement was performed. A statistically significant difference between the values is indicated with $*(p>0,05)$. Each value represents the mean \pm S.E. $n=3$. 

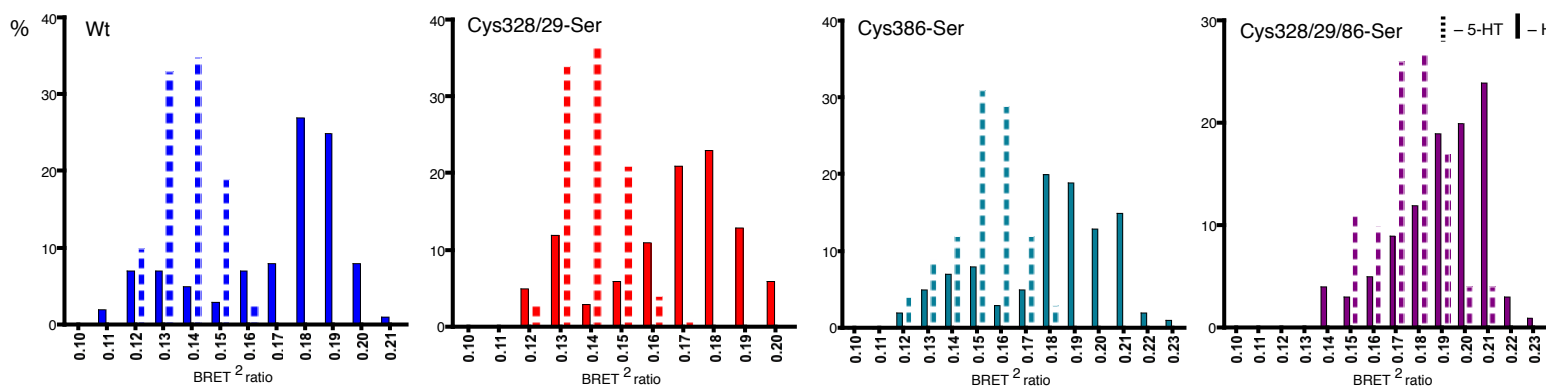

Figure 3.12 Frequency distribution analysis of BRET ratio. To proof that increase in BRET ratio is specific and caused by stimulation of the $5-\mathrm{HT}_{4(\mathrm{a})}$ rceptor with 5 -HT. Two distinct peaks in distribution of the BRET values demonstrate a shift in BRET values after serotonin application.
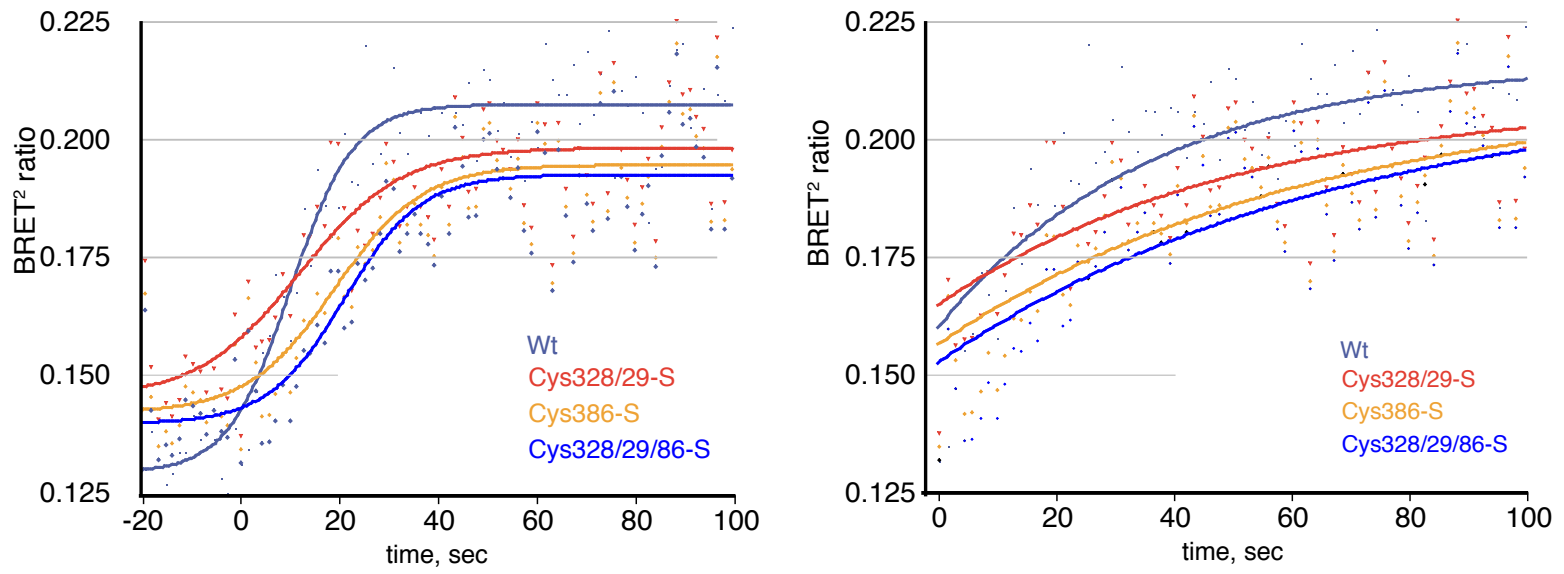

Figure 3.13 (A) Short term kinetic of the 5- $\mathrm{HT}_{4(\mathrm{a})}$ receptor and $\beta$-arrestin2 interaction was measured in HEK 293 cell co-expressing with the 5-HT $4(\mathrm{a})-$ Rluc and $\beta$-arrestin2- $\mathrm{GFP}^{2}$ constructs, and BRET ratio was calculated every 50 milliseconds. After 20 seconds starting the measurement $10 \mu \mathrm{M}$ (final conc.) of 5-HT was added to the cells and BRET measurements were continued for another 80 seconds. (B) To analyze the speed of interaction, exponential fitting eq. 2 was applied to the raw data from graph A.

\begin{tabular}{|c|c|c|c|c|c|}
\hline \multicolumn{2}{|c|}{} & Wt & Cys328/29-Ser & Cys386-Ser & Cys328/29/86-Ser \\
\hline \multirow{3}{*}{$\tau_{1 / 2}$} & - & $10,31 \pm 1,12$ & $12,12 \pm 2,98$ & $19,22 \pm 2,08$ & $21,19 \pm 1,77$ \\
\cline { 2 - 6 } & GRK2 Wt & $10,21 \pm 1,88$ & $12,11 \pm 2,96$ & $19,20 \pm 2,07$ & $21,19 \pm 1,76$ \\
\cline { 2 - 6 } & GRK2 DNM & $10,31 \pm 1,12$ & $12,12 \pm 2,98$ & $19,22 \pm 2,08$ & $21,19 \pm 1,77$ \\
\hline
\end{tabular}

Table 2. Half time of $5-\mathrm{HT}_{4(\mathrm{a})}$ receptor- $\beta$-arrestin2 interaction was calculated in presence or absence of the GRK2 wild-type or dominant negative mutant 
A

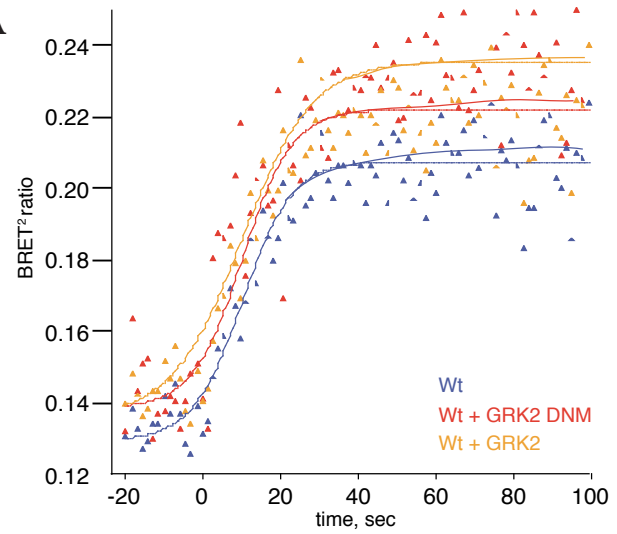

B

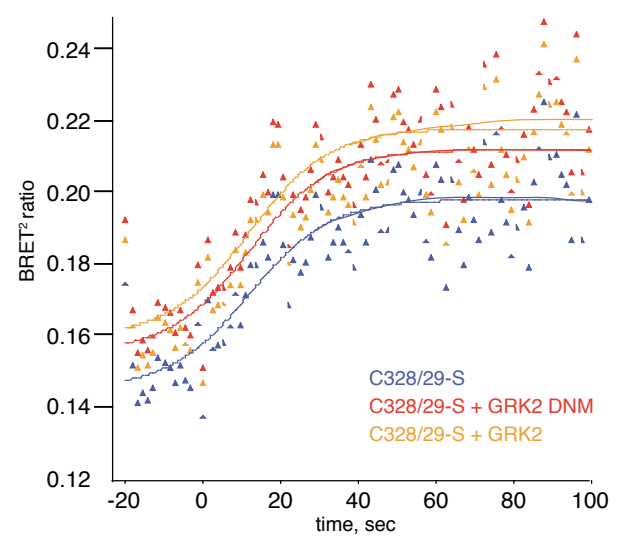

C

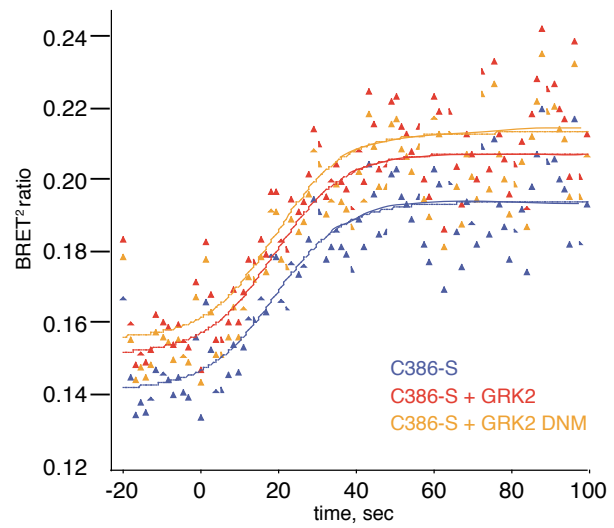

D

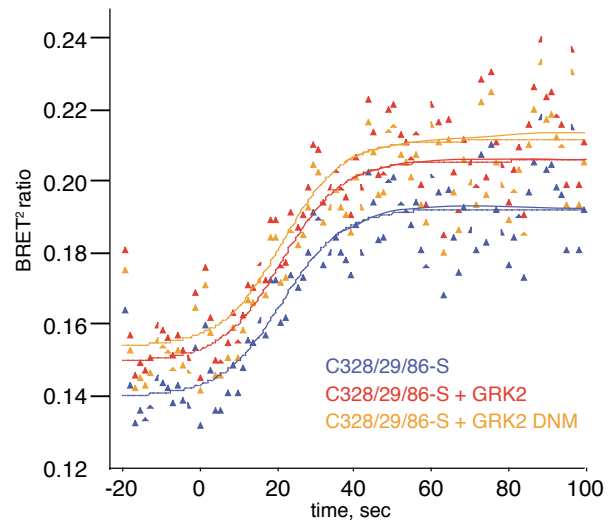

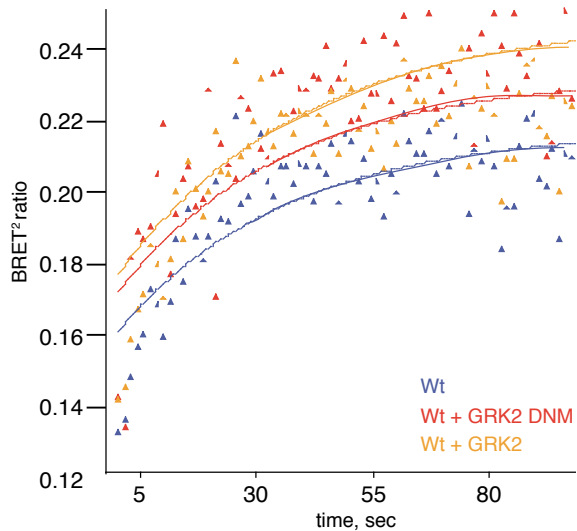
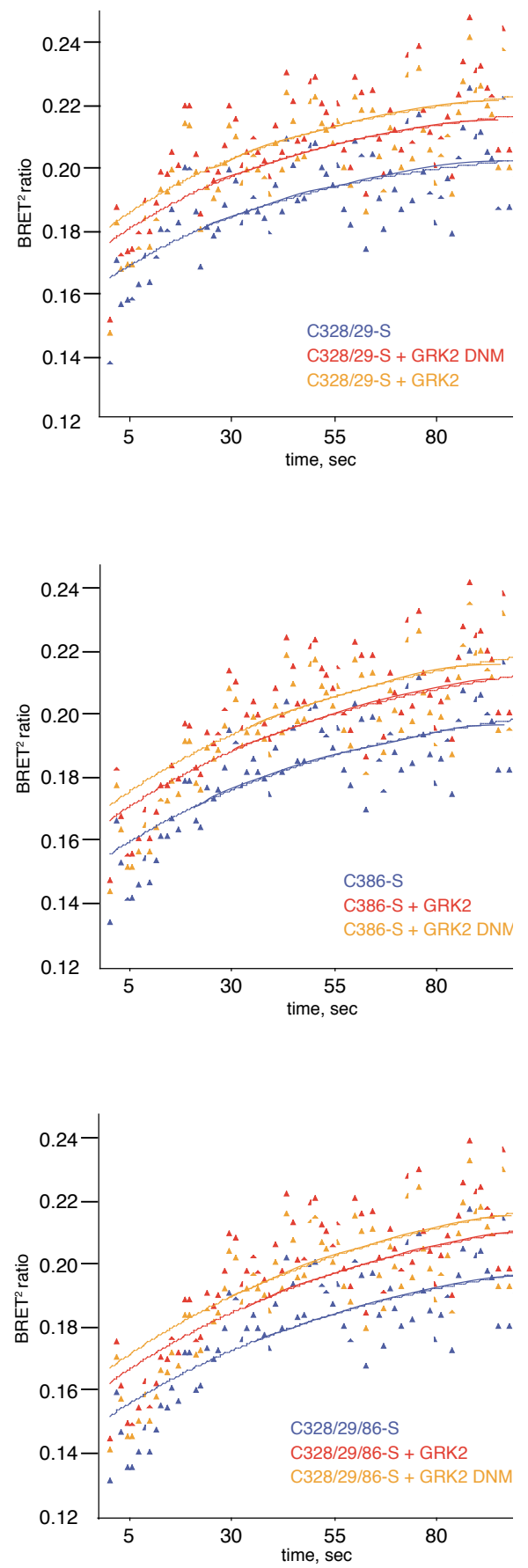
Figure 3.14 Role of GRK2 in 5-HT ${ }_{4(\mathrm{a})}$ receptor desensitization was studied in HEK 293 cells, which were co-transfected with the wild-type GRK2 or dominant negative mutant form (GRK2 DNM). Wild-type (A) and acylation-deficient mutants (B,C,D) of the 5-HT ${ }_{4(\mathrm{a})}$ receptor were analyzed. Overexpression of wild-type form of the GRK2 promotes coupling of $\beta$-arrestin2 to the $5-\mathrm{HT}_{4(\mathrm{a})}$ receptor before and after agonist stimulation. Dominant negative form of the GRK2 also promotes $\beta$-arrestin2 and 5- $\mathrm{HT}_{4(\mathrm{a})}$ receptor interaction but less efficiently than that for the wild-type GRK2.

the wild-type the $\tau_{1 / 2}$ values was $10.31 \pm 1.12$ and $12.12 \pm 2.98,19.22 \pm 2.98,21.19 \pm 1.77 \mathrm{sec}$ onds (Figure 3.13, Table 2) demonstrating that the interaction rate was slower in case of acylation-deficient mutants.

\subsection{Role of G-protein receptor kinase in receptor- $\beta$-arestin 2 interaction}

It is known that GRK2 is critically involved in the GPCRs desensitization, serving as an enzyme for receptor phosphorylation, and also may act as an adaptor protein (Oppermann et al. 1996, Tesmer et al., 2005). In our study, we obtained that overexpression of GRK2 significantly promotes $\beta$-arrestin 2 recruitment to the wild-type receptor and palmitoylation deficient mutants both with and without stimulation of the receptor by agonist (Figure 3.14. Figure 3.15). However, overexpression of GRK2 did not affect the interaction kinetic $\left(\tau_{1 / 2}\right)$ was not changed upon GRK2 overexpression (Table 2). Interestingly, overexpression of GRK2 dominant negative mutant did not abolish recruitment of $\beta$-arrestin 2 to the receptor, as one could expect based on the lack of enzymatic activity by GRK2 dominant negative mutant. Effect was slightly smaller as a fully functional GRK2 (Figure 3.14, Figure 3.15). This might be explained by the fact that the wild-type form of GRK2 has two ways of interaction with the receptor. (i) when GRK2 phosphorylate the receptor on serine/threonine residues and by this receptor became susceptible for $\beta$-arrestin mediated desensitization. (ii) GRK2 may bind directly to the receptor and serve as an adaptor protein for facilitating the desensetization of the receptor (Oppermann et al. 1996, Tesmer et al. 2005).

\subsection{Role of palmitoylation in 5-HT1A receptor localization}

\subsubsection{Generation and functional properties of 5-HT1A-YFP fusion constructs}

We have previously demonstrated that 5-HT1A receptor has a stable palmitoylation (Papoucheva et al. 2004), but the role of palmitoylation in receptor trafficking is remained unlcear. Therefore, we analyzed the function of palmitoylation in receptor-lipid rafts communication. To study 5-HT1A receptor-mediated signalling processes in living cells, enhanced yellow fluorescence protein (YFP) was fused to the C-terminal domain of the wildtype (Wt-YFP) and acylation-deficient (DM-YFP) 5-HT1A receptors after removing the stop codon (Figure 3.16A). Immunoblot analysis performed in transfected neuroblastoma 


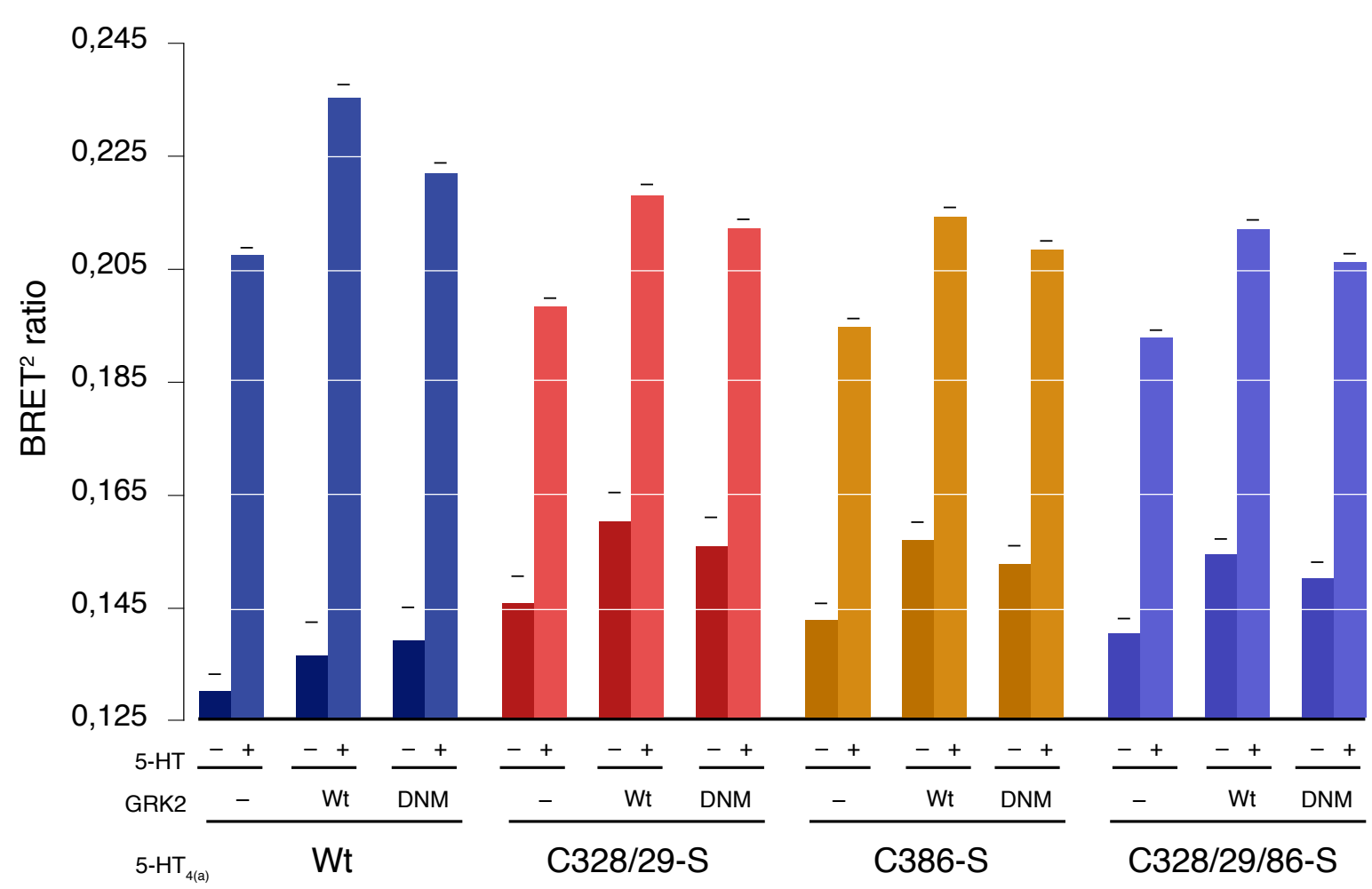

Figure 3.15 GRK2 wild-type or dominant negative mutant was co-expressed with 5-HT ${ }_{4(a)}$ wild-type or acylation deficient mutant and $\beta$-arrestin2, and BRET ${ }^{2}$ was measured in the presence or absence of 5-HT. Each value represents the mean \pm S.E. $n=3$.

N1E-115 cells revealed a protein band with a predicted molecular weight of approximately $76 \mathrm{kDa}$ for both Wt-YFP and DM-YFP constructs (Figure 3.16B).

To exclude the possibility that fusion to the YFP alters receptor properties, we analyzed the subcellular distribution, pharmacological profile as well as downstream signalling of the fluorescent-labelled receptors by comparison with the 5-HT1A-HA receptors (Papoucheva et al. 2004). Confocal microscopy performed after transient transfection of Wt-YFP or DM-YFP constructs into N1E-115 cells revealed that the major part of the YFP-tagged receptors was on the plasma membranes with only a minor fraction present in the intracellular compartments (Figure 3.16C).

The pharmacological profiles of the Wt-YFP and DM-YFP constructs were analyzed by saturation binding of the selective 5-HT1A receptor agonist $\left[{ }^{3} \mathrm{H}\right]-8-\mathrm{OH}$ DPAT in the membrane preparations from transfected NIH-3T3 cells (Figure 3.17). The binding affinities of $\left[{ }^{3} \mathrm{H}\right]-8-\mathrm{OH}$ DPAT for Wt-YFP $\left(\mathrm{K}_{\mathrm{D}}=0.72 \pm 0.53 \mathrm{nM}\right)$ and DM-YFP $\left(\mathrm{K}_{\mathrm{D}}=0,97 \pm 0,26 \mathrm{nM}\right)$ were similar to that obtained for the HA-tagged receptors $\left(\mathrm{K}_{\mathrm{D}}=0,76 \pm 0,23 \mathrm{nM}\right)$. These values are also in accordance with those previously reported (Pucadyil et al. 2004), demonstrating that the YFP fusion does not change the pharmacological properties of the 5-HT1A receptor. (Cloning were done by Dr. E. Papoucheva, microscopy and ligand binding was performed by Dr. U. Renner)

Along with the microscopy analysis and pharmacological examination we analyzed 
A

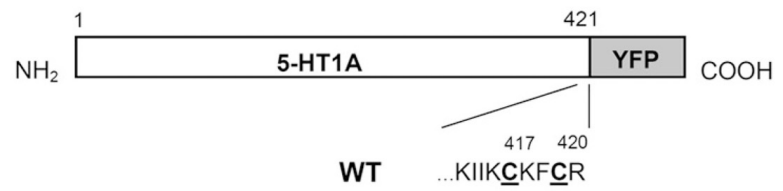

$\operatorname{DM}(\mathrm{C} 417 / 420-\mathrm{S}) \quad$ ……. s $\cdots \cdot \cdot \mathrm{s} \cdot \cdot$

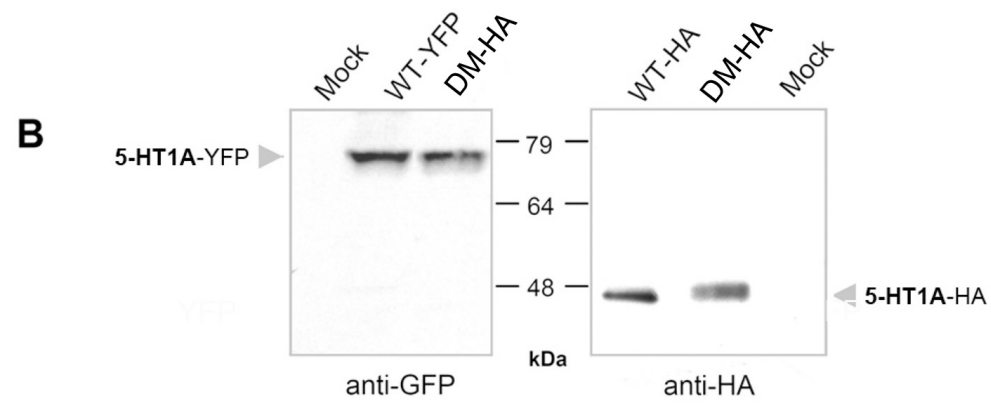

C
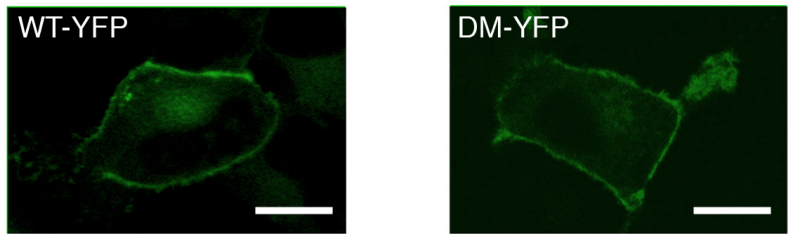

Figure 3.16 Construction and expression of the 5-HT1A-YFP receptors. (A) Schematic presentation of the wild-type and acylation deficient 5-HT1A receptors fused C-terminally with yellow fluorescent protein to produce Wt-YFP and DM-YFP constructs, respectively. C-terminal amino acid sequence of the 5-HT1A receptor is shown with a single letter code. (B) Immunoblot analysis of YFP- and HA-tagged 5-HT1A receptors transiently expressed in N1E-115 cells. The blots were probed with antibodies directed against GFP or HA-tag. The molecular weight marker is indicated between the panels. (C) Intracellular distribution of Wt-YFP and DM-YFP constructs. Representative confocal images obtained with LSM510-Meta microscope at 63x magnification are shown. Scale bar, $10 \mu \mathrm{M}$. (from manuscript Renner, Glebov et al. submitted to Mol. Pharmacol.)

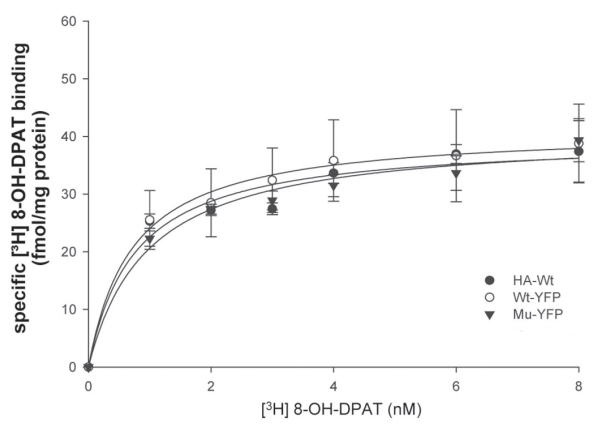

Figure 3.17 Saturation binding analysis. The plots represent specific binding of agonist $\left[{ }^{3} \mathrm{H}\right]-8 \mathrm{OH}-\mathrm{DPAT}$ to Wt-YFP, DM-YFP and HA-Wt. Radioligand binding assay was performed on membranes prepared from transfected NIH-3T3 cells. Data were fitted using the one-site saturation binding model and data points represent the means \pm S.E. from at least three independent experiments. 
signaling efficacy of YFP fused receptors by new [Eu]-GTP $\gamma \mathrm{S}$ binding assay. This assay is based on fluorescent labeled GTP $\gamma \mathrm{S}$ and does not need radioactive $\left[{ }^{36} \mathrm{~S}\right]-\mathrm{GTP} \gamma \mathrm{S}$. N1E 115 cells were transfected with HA-5-HT1A (as a positive control) or 5-HT1A-YFP wild-type or acylation-deficient . The HA-tagged and YFP-tagged 5-HT1A receptor wild-type were capable to activate $\mathrm{G \alpha}_{\mathrm{i} 3}$-protein, where the acylation-deficient form of the 5-HT1A complete lacked this ability (Figure 3.18). This data correlates with our previous observations done by Papoucheva et al. (Papoucheva et al. 2004). (Renner U, Glebov K. et al., manuscript submitted to Molecular Pharmacology).

\subsubsection{Distribution of wild-type and palmitoylation-deficient 5-HT1A re- ceptors within membrane subdomains}

Lipid modifications have been shown to play a role in the partitioning of several proteins into defined membrane subdomains, like lipid rafts and caveolae (Arni et al. 1998, Melkonian et al. 1999, Moffett et al. 2000). To determine, whether this may be the case for the 5-HT1A receptor, we compared the membrane distribution of the wild-type receptor and acylation-deficient mutant using density gradient centrifugation. Immunoblot analysis of gradient fractions revealed that $33 \pm 11 \%(n=4)$ of the wild-type 5 -HT1A and to $4 \pm 3 \%(n=4)$ of the 5-HT1A receptor floated with the detergent-resistant low-density fractions along with the caveolae-specific protein caveolin-1 and the $\mathrm{G \alpha}_{\mathrm{i} 3}$-subunit of heterotrimeric G-protein (Figure 3.19). It is also notable that distribution of the raft- as well as non-raft markers did not change in cell expressing DM-YFP, when compared to the corresponding fractions

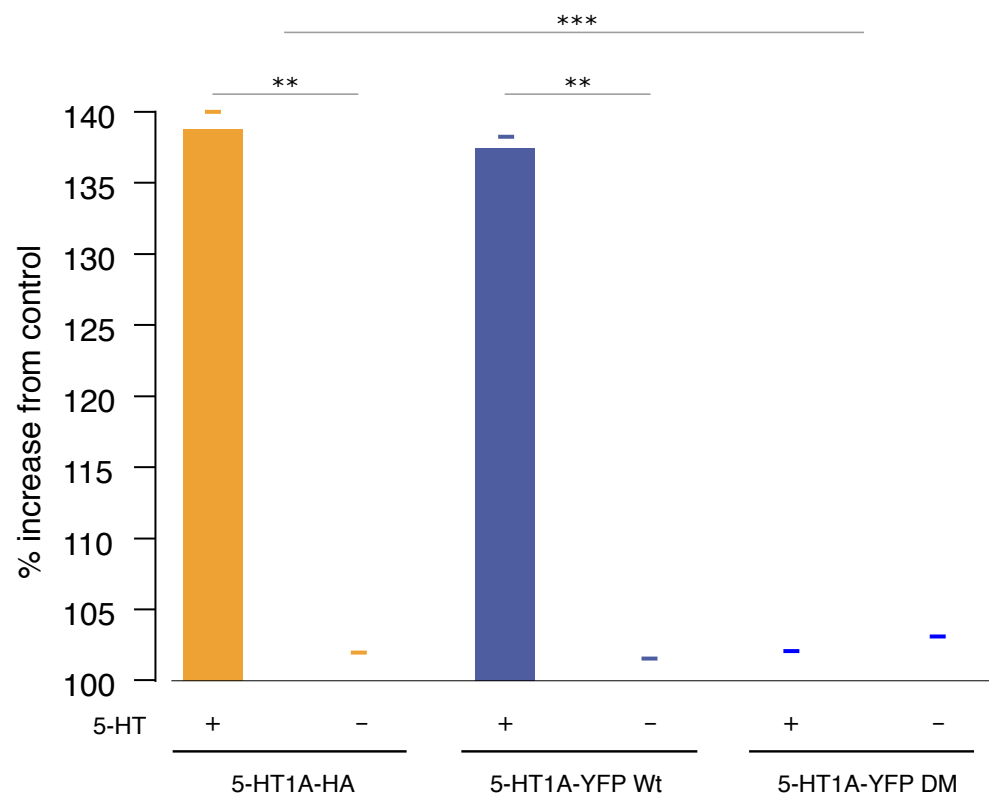

Figure 3.18 The ability of diffirent tagged receptors to stimulate $\mathrm{G \alpha}_{\mathrm{i} 3}$ after application of agonist $(10 \mu \mathrm{M})$ was analysed, for 5-HT1A-HA, 5-HT1A-YFP wild-type or acylation deficient mutants. Binding of [Eu]-GT$\mathrm{P} \gamma \mathrm{S}$ to the $\mathrm{G \alpha}_{\mathrm{i} 3}$ subunit was analysed asdescribed in materials and methods. Data represented as mean $\pm \mathrm{S}$.E. $(* *, \mathrm{p}<0,05 ; * * *, \mathrm{p}<0,01) \mathrm{n}=2$. 
generated from the Wt-YFP expressing cells (Figure 3.19). This result suggests that palmitoylation represents a targeting signal responsible for the partial localization of the 5-HT1A receptor in lipid rafts. This assumption was further supported by the observation that the pre-treatment of cells with methyl- $\beta$-cyclodextrin $(\mathrm{M} B C D)$ significantly reduced the amount of Wt-YFP receptor and $\mathrm{G \alpha}_{\mathrm{i} 3}$-subunit in the low density fractions (not shown, Renner U., Glebov K. et al., manuscript submitted to Molecular Pharmacology). The cholesterol binding agent $\mathrm{M} B \mathrm{CD}$ was previously shown to disrupt the cholesterol-enriched membrane subdomains by depletion of cholesterol from the plasma membrane (Harder et al. 1998). (Renner U., Glebov K. et al., manuscript submitted to Mol. Pharmacol.)

Gradient centrifugation after solubilization with cold TX-100 is a classical way to study subcellular distribution of proteins in lipid rafts. To verify these results, we applied fluorescence microscopy techniques to analyze the association of 5-HT1A receptor with lipid rafts on native plasma membrane sheets by using a copatching assay (Harder et al. 1998). Membrane sheets from the cells stably expressing the wild-type or double mutant of 5-HT1A receptor, were prepared by a brief ultrasound pulse, leaving behind the basal plasma membrane attached to the glass coverslip (Lang et al. 2001). After fixation of membrane sheets, lipid rafts were visualized by the treatment with the cholera toxin (CTX), which binds to the raft-associated ganglioside GM1. As shown in Figure 3.20, both GM1 and 5-HT1A-YFP receptor signals were highly abundant and relative homogenous, thus not allowing to differentiate between specific and random colocalization. Therefore, segregation of the lipid rafts and receptors in more distinct domains was induced by incubating the native versus fixed membrane sheets with low concentrations of CTX and an anti-GFP antibody, respectively, in order to crosslink the corresponding domains (Spiegel et al. 1984).

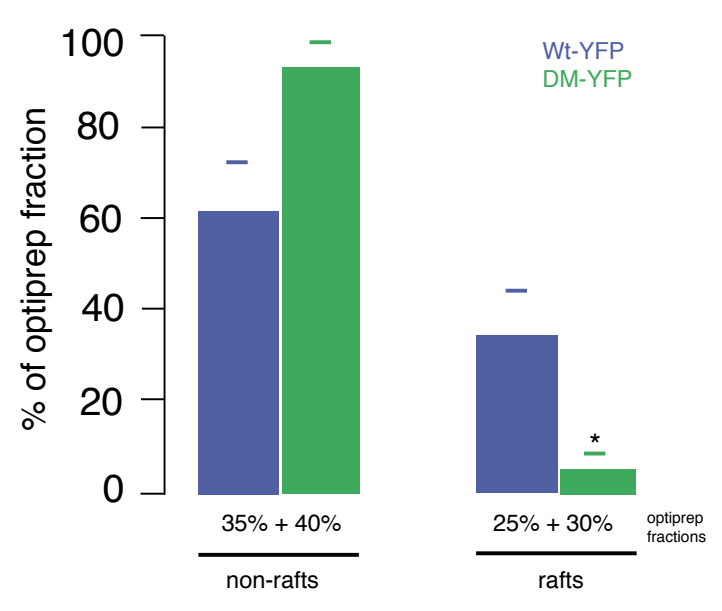

Figure 3.19 The NIH-3T3 cells stably expressing either the 5-HT1A-YFP Wt or the 5-HT1A-YFP double mutant were lysed with the cold 1\% Triton-X100 and lysates were ultracentrifugated in the OptiprepTM density gradient. The gradient fractions were analysed by immunoblotting. Relative amount of the receptor in the high density fractions $(35 \%+40 \%)$ and the buoyant low density fractions $(25 \%+30 \%)$. A statistically significant difference between values is noted $(*, p<0,05)$. 
A

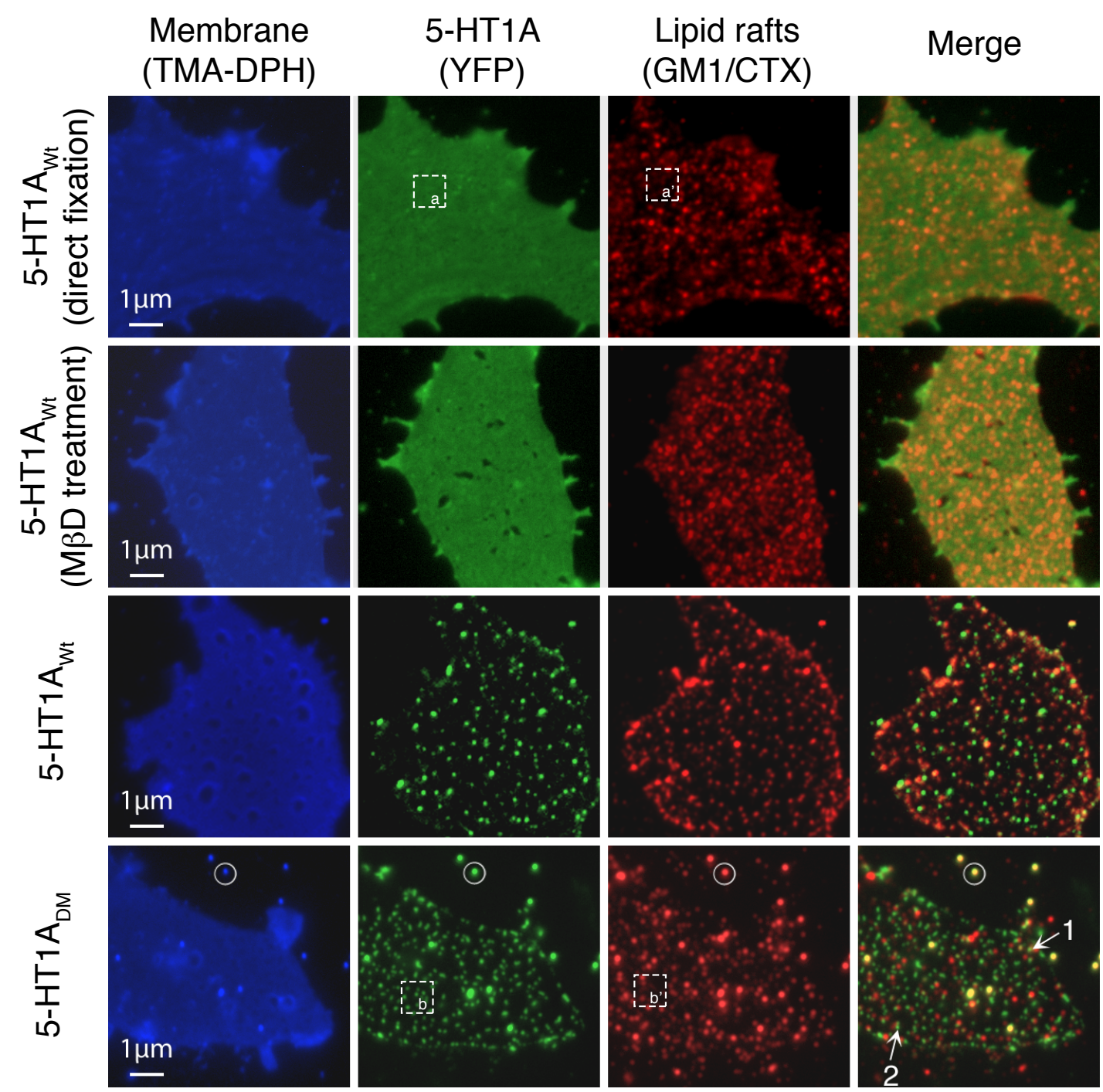

B

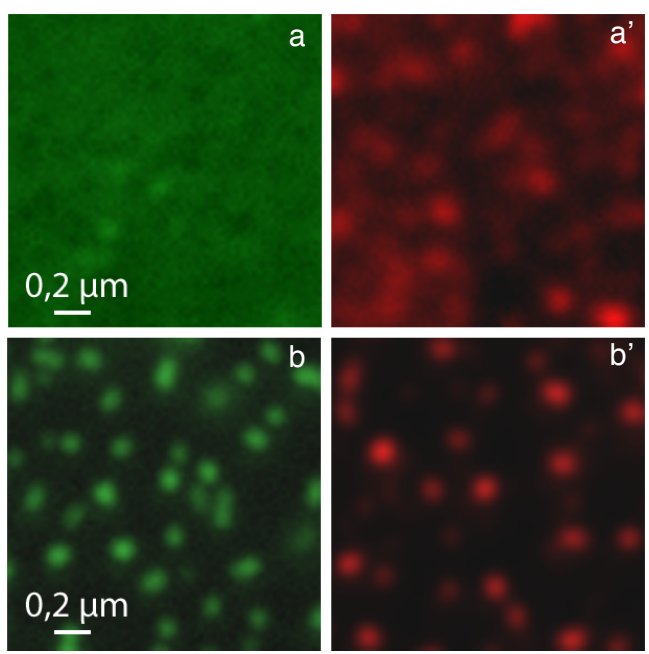

C

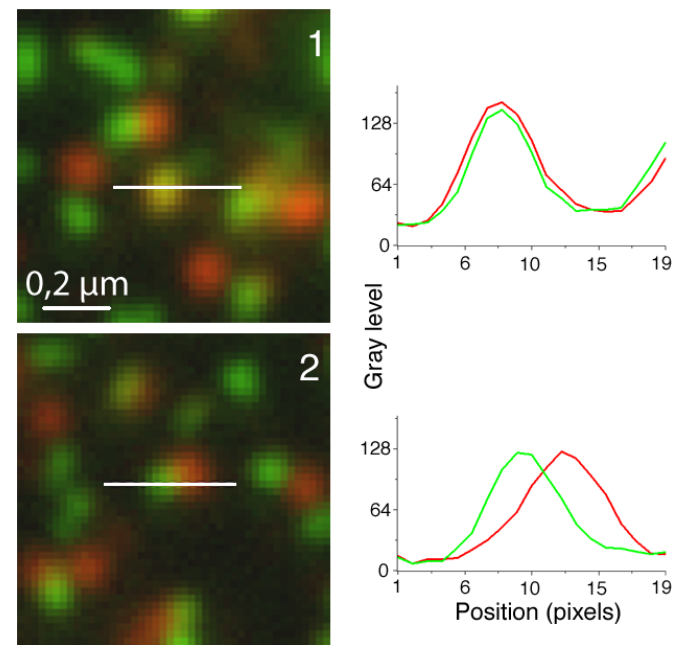


Figure 3.20 (A) Co-patching assay was performed in plasma membrane sheets derived from the stably transfected NIH-3T3 cells. Staining of the membrane lipids with TMA-DPH (blue). Co-patching of 5-HT1AYFP receptors with anti-GFP antibody (green). Co-patching of GM1 with cholera toxin. GM1 patches were detected using Alexa546 anti-CTX antibody (red). Membrane sheets were fixed before incubation with anti-GFP antibody and CTX. (direct fixation). Distribution of Wt-YFP and ganglioside GM1 after cholesterol depletion with methyl- $\beta$-cyclodextran $(M \beta D$ treatment $)$. Both experiments served as negative controls. Membrane sheets were fixed after incubation with anti-GFP antibody and CTX (5-HT1 $A_{W t}$ and 5-HT1 $\left.A_{D M}\right)$. Circles mark the fluorescent beads which were used to align images obtained in different fluorescence channels for quantitative analysis. (B) Distribution of 5-HT1 $\mathrm{A}_{\mathrm{wt}}$ (a) and lipid rafts marker GM1/CTX (a') in the membrane sheets in the absence of the crosslinking reagents. And after co-patching procedure, 5-HT1 $\mathrm{A}_{\mathrm{DM}}(\mathbf{b})$ and GM1/CTX (b') . (C) Example of the line scans analysis for regions 1 and 2, which are shown with arrows in (A, 5-HT1 $\left.A_{D M}\right)$. Fluorescence intensity was analysed pixel by pixel along the line applied on the merge pictures. When the distance between the maximal values obtained for green and red fluorescence was less than two pixels, a co-localization event was counted (1). Otherwise, patches were counted as non colocalized (2).

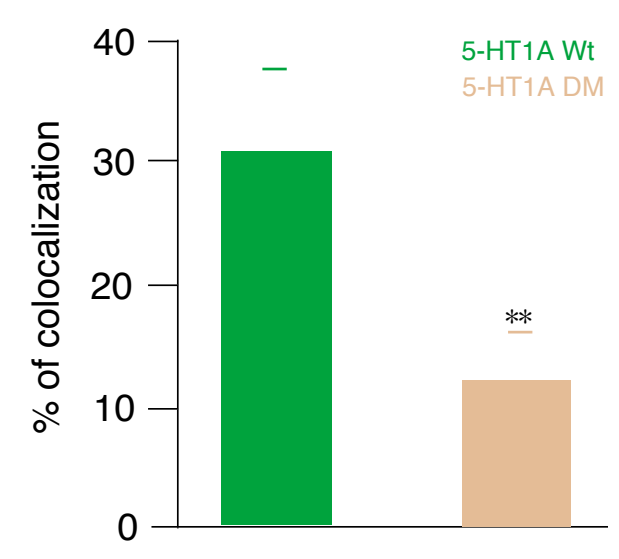

Figure 3.21 Quantitative analysis of co-localization events between the wild-type (Wt) or acylation deficient (DM) of 5-HT1A receptor and GM1/CTX. Results presented as mean \pm S.E. (n=3). A statistically significant difference between values is noted $(* *, p<0.01)$.

Such treatment resulted in the concentration of both labels in less numerous and clearly defined spots that were scattered over the membrane surface (Eigure $3.20 \mathrm{~A} 5-\mathrm{HT} 1 \mathrm{~A}_{\mathrm{Wt}, \mathrm{DM}}$ ). It is also noteworthy that the depletion of cholesterol by treatment of the intact membrane sheets with $\mathrm{MBCD}$ resulted in more homogenous distribution of both receptor and GM1 fluorescence (Figure 3.20A 5-HT1A $\mathrm{N}_{\mathbf{1}} \mathrm{M} \beta \mathrm{D}$ treatment).

A detailed analysis of the 5-HT1A receptor and GM1-derived fluorescence patterns revealed that $30,3 \pm 4,1 \%$ of the wild-type receptor patches were also enriched with the lipid raft marker GM1. Importantly, this value was 3-fold reduced for the acylation-deficient mutant (Figure 3.21). These data demonstrate that a significant fraction of the 5-HT1A receptor is associated with the lipid rafts. These findings are also in line with the gradient centrifugation data suggesting the importance of palmitoylation for localization of the 5-HT1A receptor in the lipid rafts. 


\section{Discussion}

\subsection{Role of palmitoylation on $5-\mathrm{HT}_{4(\mathrm{a})}$ receptor functioning}

\subsubsection{Phosphorylation of the 5- $\mathrm{HT}_{4(\mathrm{a})}$ receptor}

Our results demonstrate that the $5-\mathrm{HT}_{4(\mathrm{a})}$ receptor is a substrate for phosphorylation by endogenous cellular kinase(s) upon exposure to agonist. A prominent role for G-protein receptor kinases in the phosphorylation of the $5-\mathrm{HT}_{4(\mathrm{a})}$ receptor based on following observations: (i) neither activation nor inhibition of PKA, the kinase activated downstream of the $5-\mathrm{HT}_{4(\mathrm{a})}$ receptor, or other second messenger-activated protein kinases, such as protein kinase $\mathrm{C}$ or calmodulin kinase, affected $5-\mathrm{HT}_{4(\mathrm{a})}$ receptor phosphorylation in a noticeable manner; (ii) the $5-\mathrm{HT}_{4(\mathrm{a})}$ receptor is rapidly $\left(\tau_{1 / 2}=2 \mathrm{~min}\right)$ phosphorylated upon agonist stimulation, and the concentration dependence of receptor phosphorylation $\left(\mathrm{EC}_{50}=180 \mathrm{nM} 5\right.$-HT) strictly followed ligand occupancy.

This finding is unexpected, because the receptor's third intracellular loop as well as the carboxyl terminus contains consensus sites for phosphorylation by protein kinase $\mathrm{C}$ and calcium/calmodulin-dependent kinase. A close correlation between dose-dependent receptor phosphorylation and ligand binding together with the apparent lack of any effect of second messenger-activated protein kinases strongly suggests the involvement of one or more G-protein coupled receptor kinases (GRKs), because they specifically phosphorylate only agonist-occupied receptors (Bunemann and Hosey 1999). GRKs from insects and mammals are evolutionarily conserved, which may explain why these kinases are capable of phosphorylating a wide range of receptor substrates (Cassill et al. 1991). Examination of the $5-\mathrm{HT}_{4(\mathrm{a})}$ receptor $\mathrm{C}$-terminus reveals the existence of several potential serine or threonine phosphorylation sites. Some of these sites (e.g., Ser382 or Ser385) are highly conserved among human, rat, and murine $5-\mathrm{HT}_{4(\mathrm{a})}$ receptors. These serine residues are flanked by negatively charged amino acids, which previously were found to promote GRK-mediated phosphorylation (Onorato et al. 1991). Moreover, phosphoamino acid analysis revealed that ligand induced phosphorylation of the $5-\mathrm{HT}_{4\{\mathrm{a})}$ receptor occurs exclusively on serine residues. It remains to be determined which of the six $\mathrm{C}$-terminal serine residues, or possibly other serines located on cytoplasmic loops of the receptor, constitute phospho-acceptor sites for receptor kinases.

\subsubsection{Interaction between palmitoylation and phosphorylation}

It is well documented that many GPCRs can be modified by both palmitoylation and phosphorylation and that these two post-translational modifications are interrelated. The findings of the present study are reminiscent of earlier work on the $\beta 2$-adrenergic receptor in which a Cys341-Gly palmitoylation mutant found to be hyperphosphorylated at basal levels could not be enhanced by further stimulation (Moffett et al. 1993). It was concluded that 
lack of palmitoylated cysteine exposes a PKA phosphorylation site juxtaposed to the palmitoylation site. A marked increase in basal phosphorylation as a result of mutating two putative cysteine palmitoylation sites was also observed in the A3 adenosine receptor (Palmer and Stiles 2000). However, GPCRs in their depalmitoylated states are not always better targets for receptor kinases. For example, a palmitoylation-deficient variant of the CCR5 chemokine receptor is not efficiently phosphorylated and reveals a profound defect in receptor desensitization and internalization (Kraft et al. 2001). Similar defects were observed for the vasopressin V1a receptor (Hawtin et al. 2001), whereas elimination of the two palmitoylated cysteine residues in the related V2 vasopressin receptor did not change basal or agoniststimulated phosphorylation (Sadeghi et al. 1997). Moreover, a mass spectrometric study of post-translational modifications of the bradykinin B2 receptor revealed that palmitoylation at Cys356 and phosphorylation at Tyr352 were mutually exclusive (Soskic et al. 1999). Taken together, these studies clearly show that in GPCRs, palmitoylation and phosphorylation are often interrelated, albeit in different ways.

Agonist-induced 5- $\mathrm{HT}_{4(\mathrm{a})}$ receptor phosphorylation established in the present study seems to be functionally significant. Previously it was reported that 5- $\mathrm{HT}_{4}$ receptors expressed in colliculus neurons undergo homologous receptor desensitization (Ansanay et al. 1992). Neither activation nor inhibition of cAMP-dependent protein kinase affected receptor desensitization, whereas inhibitors of G-protein-coupled receptor kinases, such as heparin or $\mathrm{Zn}^{2+}$, caused significant decrease in 5-HT-induced receptor desensitization. Similar to the present findings on 5- $\mathrm{HT}_{4(\mathrm{a})}$ receptor regulation in a heterologous expression system, the $5-\mathrm{HT}_{4}$ receptor desensitization in native tissues also proceeded in a biphasic manner and possessed comparable kinetics of the rapid phase of receptor desensitization (Ansanay et al. 1992). Further support for a role for GRKs in $5-\mathrm{HT}_{4(\mathrm{a})}$ receptor regulation derives from the observation that overexpression of GRK2 significantly enhanced 5-HT ${ }_{4(\mathrm{a})}$ receptor desensitization. A role for PKA in 5- $\mathrm{HT}_{4}$ receptor regulation was also suggested recently based on the observation that receptor-independent activation of PKA could mimic 5-HT induced desensitization of the 5- $\mathrm{HT}_{4(\mathrm{~d})}$ receptor isoforms (Mialet et al. 2003). However, mutation of the four PKA consensus sites on this receptor did not impair PKA-induced 5-HT $\mathrm{H}_{4(\mathrm{~d})}$ receptor desensitization. In combination with our finding that, on its own, PKA activation did not result in 5- $\mathrm{HT}_{4(\mathrm{a})}$ receptor phosphorylation, this implies that PKA may phosphorylate another protein substrate downstream of this receptor. Adenylyl cyclase, which is inhibited by PKA phosphorylation (Iwami et al. 1995), is a potential substrate for such a regulation.

The 5-HT $\mathrm{H}_{4(\mathrm{a})}$ receptor is atypical among GPCRs because of the presence of two separate $\mathrm{C}$-terminal palmitoylation sites operating as potential membrane anchorage points at positions Cys-328/329 and Cys-386. Together with the observation that the palmitoylation state of the receptor is agonist sensitive (Ponimaskin et al. 2001), this dual lipidation suggests that in a native cellular environment, the $5-\mathrm{HT}_{4(\mathrm{a})}$ receptor $\mathrm{C}$ terminus exists in sev- 
eral different conformational states that can be modulated by external stimuli. In the present work, we tested the hypothesis that regulatory cytoplasmic proteins, which bind to or phosphorylate the C-terminal domain, may interact with these receptor conformers in a differential manner. Earlier studies in which the same receptor variants were used, revealed that mutation of the proximal Cys-328/329 couplet resulted in elevated constitutive activity of this receptor (Ponimaskin et al. 2002a). In contrast, mutations of the distal Cys-386 or of all C-terminal palmitoylation sites showed no increase in the basal activity. We concluded from these studies that defective palmitoylation at the proximal membrane anchorage site induces a conformation of the $5-\mathrm{HT}_{4(\mathrm{a})} \mathrm{C}$-terminus to facilitate receptor binding and/or activation of heterotrimeric G-proteins (Ponimaskin et al. 2002a). Our present finding of elevated basal phosphorylation levels of the proximal Cys328/329-Ser mutant may be caused by its higher constitutive activity, as was reported before in other receptor systems (Pei et al. 1994). This interpretation, however, does not explain why the Cys386-Ser mutant and the completely palmitoylation-deficient receptor are also better substrates for receptor kinases. Conformational changes occurring at the C-terminus during basal or agonist-stimulated depalmitoylation of the receptor possibly lead to an exposure of one or several protein kinase binding site(s). Such receptor structure seems not to be identical with the conformation that is optimal for G-protein activation. Several putative serine phosphorylation sites are located near the palmitoylated $\mathrm{C}$-terminal cysteine residues, which supports the assumption that palmitoylation may restrain access of these sites to the receptor kinase. Enhanced receptor phosphorylation in case of the palmitoylation- deficient mutants could also be caused by the presence of additional phospho-acceptor sites that may have been introduced by the conservative replacement of cysteine by serine residues. However, this seems unlikely, because the triple mutant Cys328/329/386-Ser was phosphorylated even less than the single or double mutants.

\subsubsection{Role of palmitoylation in $\beta$-arrestin2 mediated desensitization and internalization of the $5-\mathrm{HT}_{4(\mathrm{a})}$ receptor}

A receptor with a lack of palmitoylation site seems to be a preferred substrate for receptor kinases and is obviously most susceptible to ligand-induced desensitization and $\beta$-arrestin mediated internalization. These findings demonstrate that the palmitoylation status of the $5-\mathrm{HT}_{4(\mathrm{a})}$ receptor modifies its ability to interact with other downstream regulatory proteins. The receptor mutants were affected in their capacity to undergo agonist-independent receptor activation, phosphorylation, desensitization and $\beta$-arrestin mediated internalization with different rank orders, which suggests that interactions of regulatory proteins with the palmitoylated receptor have different structural requirements. Although all receptor mutants were hyperphosphorylated, only the Cys328/329-Ser mutant was rapidly and efficiently internalized in $\beta$-arrestin overexpressing cells. Thus, it is unlikely that GRK-mediated hyperphosphorylation alone is responsible for the enhanced endocytosis. Instead, 
our data suggest that the Cys328/329-Ser receptor mutant, having only a single palmitoylation site distal to the membrane, represents a specific receptor conformation facilitating $\beta$-arrestin mediated endocytosis. According to the sequential multisite model of $\beta$-arrestin interaction with ligand-activated receptors, high-affinity binding of arrestin to GPCR involves two separate phosphorylation-recognition and activation-recognition sites that reside within different parts of the molecule (Han et al. 2001). We did not directly assess $\beta$-arrestin binding to palmitoylation-deficient receptor mutants, as was reported previously for the V2 vasopressin receptor (Charest and Bouvier 2003). In contrast to 5-HT $4(\mathrm{a})$ receptors, nonpalmitoylated V2 vasopressin receptor showed no difference in basal or agonist-induced phosphorylation, but is much more slowly internalized than wild-type receptors (Charest and Bouvier 2003,Sadeghi et al. 1997). Mutation of the palmitoylation site also decreased the rate and the extent of $\beta$-arrestin recruitment to this receptor. Likewise, receptor palmitoylation was also found to be required for ligand-induced $\beta$-arrestin recruitment to the cell membrane and endocytosis of the thyrotropin-releasing hormone receptor (Groarke et al. 2001). On the contrary, mutation of the membrane-proximal palmitoylation site facilitates $\beta$-arrestin mediated internalization of $5-\mathrm{HT}_{4(\mathrm{a})}$ receptors.

In summary, our study shows that $5-\mathrm{HT}_{4(\mathrm{a})}$ receptor palmitoylation is functionally significant, because disruption of C-terminal palmitoylation sites resulted in enhanced receptor phosphorylation, desensitization, and $\beta$-arrestin-mediated endocytosis. Because both the phosphorylation and the palmitoylation status of the $5-\mathrm{HT}_{4(\mathrm{a})}$ receptor are dynamically regulated by agonist stimulation, concerted interactions of these two post-translational modifications seem to play an essential role in modulating the function of $5-\mathrm{HT}_{4(\mathrm{a})}$ receptors.

\subsubsection{Role of palmitoylation in short term interaction between $5-\mathrm{HT}_{4(\mathrm{a})}$ re- ceptor and $\beta$-arrestin2; BRET $^{2}$ analysis}

Biochemical methods used in this study including measurement of cAMP and radioligand binding assay as readout are present classical approaches to analyze desensitization and internalization of GPCRs. However, these methods require solubilization and concentration of membrane proteins which could result in artificial results. In addition, these techniques do not allow a dynamical analysis of GPCR desensitization in living cells with high temporal resolution. On the other hand, initial steps of desensitization in particular interaction between $\beta$-arrestin and receptor are known to be quick processes with a time scale ranging from milliseconds to seconds (Fotiadis at al. 2006, Lohse et al. 1990). To overcome these limitations and to analyze receptor desensitization in living cells we applied BRET method. Since no external excitation source is needed for BRET assays, this approach does not suffer from high fluorescent background or photobleaching which take place in fluorescence-based FRET method (Miligan 2004, Pfleger and Eidne 2003). Currently this assay is often used for analysis of receptor oligomeresation (Angers et al. 2001, 2000, GermainDesprez et al. 2003, Issafras et al. 2002). However, BRET approach can also be utilized for 
analysis of interaction between GPCRs and $\beta$-arrestin (Angers et al. 2000, Kroeger et al. 2001). Moreover, the BRET method can be extended to give a wealth of information about detailed kinetic of interaction over a short period of time (Kroeger et al. 2001). To apply such time-resolved BRET assay for the analysis of 5-HT4 receptor desensitization we create fusion constructs between the wild-type and acylation-deficient mutant of 5-HT $\mathrm{H}_{4(\mathrm{a})}$ receptor with Renilla luciferase protein. Functionality of receptor-luciferase constructs was assessed by the analysis of their subcellular distribution and by pharmacological studies. In all cases, luciferase chimeras demonstrated similar responses as their unlabeled wild-type or acylation-deficient counterparts, indicating that Rluc-fused receptors can be used in functional studies.

To study short term kinetic of the $\beta$-arrestin recruitment to the receptor and analyzed the role of GRK2 in this process, we applied BRET ${ }^{2}$ assay. This is a second generation of BRET assay, which utilizes new DeepBlueC ${ }^{\text {TM }}$ substrate instead of CoelenterazineC, which is a classical substrate for BRET studies. In addition a new version of classical GFP, so called GFP ${ }^{2}$ with changed spectral options is used as an acceptor. These modification resulted in improved diference between emmission spectra of luciferase and GFP in comparison with a classical BRET assay. As a consequence of this we have a lower background and better signal to noise ratio.

To establish the BRET ${ }^{2}$ method in our laboratory we used the HEK 293 cells co-expressing Renilla luciferase-GFP ${ }^{2}$ chimeric protein as positive control. While cells coexpressing Renilla luciferase and $\mathrm{GFP}^{2}$ proteins were used as negative controls. These experiments demonstrate that $\mathrm{BRET}^{2}$ assay is a highly reproducible method, with a very high signal to noise ratio. To be able to compare the results from diffirent BRET trials as well as use the physiological concentration of the receptor, we defined expression level in every individual measurement. For that, we used instead of radioligand binding, which is very time consuming way to determine concentration of the receptor, new normalization approach where we have used linear dependence between the receptor surface expression and the donor luminescence intensity. For this we applied another form of Coelenterazine $\mathrm{C}$ - Colenterazine $\mathrm{H}$, which allows to measure the absolute luminescence of the donor without influencing the energy transfer to a $\mathrm{GFP}^{2}$ (acceptor) mediated by DeepBlueC (Gales et al. 2005).

At first, we analyzed dose dependence of the receptor- $\beta$-arrestin 2 interaction after administration of different concentrations of serotonin. Application of serotonin promote $\beta$-arrestin interaction with the wild-type form of the $5-\mathrm{HT}_{4(\mathrm{a})}$ receptor as well with its acylation-deficient mutants. This was in line with previous observations demonstrating increase in receptor- $\beta$-arrestin interaction in case of V2 vasopressin and thyrotropin-releasing hormone receptors after stimulation with AVP or TRH respectively (Charest and Bouvier 2003, Hanyaloglu et al. 2002). Analysis of BRET data for acylation-deficient mutants revealed a 
high level of basal interaction with $\beta$-arrestin. This findings can be explained by our previous observation of a higher basal level of phosphorylation of these mutants.

Activation of the GPCR mediated cascades has been shown to be very quick process. Activation of G-protein by the corresponding receptor occurs a few milliseconds after agonist stimulation, while downstream signaling cascade is activated within hundreds of milliseconds. This sugests that receptor phosphorylation by receptor kinase followed by $\beta$-arrestin binding and desensitization should also start in the time range from milliseconds to seconds. To investigate receptor- $\beta$-arrestin 2 interaction in such short time range we applied short kinetic BRET ${ }^{2}$ analysis (Gales et al. 2005). By this, we analyzed kinetic of interaction between the $5-\mathrm{HT}_{4(\mathrm{a})}$ receptor and $\beta$-arrestin2. Half time of interaction $\tau_{1 / 2}$ was calculated for wild-type and all mutants, and was found to be $10.31 \pm 1.12,12.12 \pm 2.98$, $19.22 \pm 2.08,21.19 \pm 1.77$ seconds for the wild-type, C328/29-S, C386-S, C328/29/86-S respectively. Slower interaction kinetic (i.e. higher $\tau_{1 / 2}$ values) obtained for acylation-deficient mutants may be explained by their higher level of basal phosphorylation which we obtained for all mutants. Such high basal phosphorylation results in low increase over the basal level after agonist stimulation, because of limited numbers of free sites for phosphorylation at the moment of agonist application. This may results in relative low rate of recruitment of $\beta$-arrestin 2 to the mutants, resulting in low increase in $\beta$-arrestin 2 coupling in comparison with the wild-type.

Based on analysis of the phosphorylation of the 5- $\mathrm{HT}_{4(\mathrm{a})}$ receptor after activation of different protein kinases and staurosporin, we conclude that GRK2 might be main kinase involved in the receptor phosphorylation. To examine role of this kinase in more details we utilized BRET ${ }^{2}$ measurements in the absence or presence of GRK2 wild-type or its dominant negative mutant (DNM) (Oppermann et al. 1996). Co-expression of GRK2 Wt and DNM did not change kinetic of the receptor- $\beta$-arrestin2 interaction $\left(\tau_{1 / 2}\right)$ for the wildtype and acylation-deficient mutants. However, BRET values obtained after overexpression of GRK2 for all 5-HT $\mathrm{H}_{4(\mathrm{a})}$ receptor tested were higher then measured in experiments without GRK2 overexpression. In case of dominant negative form of GRK2, BRET values were lower as these obtained for GRK2 Wt overexpression but still higher as values obtained in the case without overexpression of GRK2. This phenomenon can be explained by the recent findings describing mechanisms in GRK2 functions. It has been shown that GRK2 has enzymatic activity, and phosphorylates receptors on their serine/threonine residues quickly after receptor activation (Bunemann and Hosey 1999). Moreover it may directly couple to the receptor and promotes its desensitization by serving as an adaptor protein (Oppermann et al. 1996, Tesmer et al. 2005). Dominant negative mutant lack the enzymatic activity by mutation of the lysine at position 220 to arginine in the catalytic center of the enzyme (Kong et al. 1994, Oppermann et al. 1996). Therefore GRK2 DNM may only act by direct binding, resulting in a debilitation of the GRK2 activity (Kong et al. 1994, Opperman et al. 1996, 
Tesmer et al. 2005).

\subsection{Role of palmitoylation in the 5-HT1A receptor functioning}

The convenience of GFP labelling in combination with the recent advances in imaging techniques has not only allowed for qualitative, but also quantitative analysis of protein localization, trafficking and mobility in living cells (Chudakov et al. 2005). More specifically, fluorescence labelling of GPCRs represents a powerful tool for direct visualization of receptor-mediated signalling in real time (Kallal and Benovic 2000,Milligan 2004). In the second part of our study we used YFP-tagged 5-HT1A receptor wild-type (Wt-YFP) and its acylation-deficient mutant (DM-YFP) to analyse their subcellular dynamics and to elucidate the role of the receptor palmitoylation.

Functionality of receptor-YFP constructs was assessed by the analysis of their subcellular distribution and by pharmacological studies. In addition, the efficiency of downstream signalling was tested by receptor-dependent activation of extracellular signal-regulated kinases. In all cases, YFP-chimeras demonstrated similar responses as their non-fluorescent wildtype or acylation-deficient counterparts, indicating that YFP-fused receptors can be used in functional studies. In addition, the efficiency of downstream signalling was tested by receptor-dependent activation of extracellular signal-regulated kinases and $\mathrm{Ca}^{2+}$ release. In all cases, YFP-chimera demonstrated similar responses as their non-fluorescent wild-type or acylation-deficient counterparts, indicating that YFP-fused receptors can be used in functional studies.

\subsubsection{Palmitoylation and localization of the 5-HT1A receptor in plasma membrane microdomains}

We have previously demonstrated that the 5-HT1A receptor is palmitoylated at its C-terminal cysteine residues Cys417 and Cys420. Characterization of acylation-deficient 5-HT1A mutants revealed the importance of receptor palmitoylation for the signaling (Papoucheva et al. 2004). However, the molecular mechanisms by which palmitoylation may regulate receptor-dependent G-protein activation are still unknown. One possibility could be the involvement of the 5-HT1A receptor palmitoylation in trafficking and/or localization of the receptor into the specific membrane subdomains, like lipid rafts.

Protein modification by the covalent attachment of saturated fatty acyl chains, including myristic and palmitic acids represents one of the best characterized lipid raft targeting signals (Moffett et al. 2000, Zacharias et al. 2002). The long-chain fatty acids are expected to pack well in the $1_{0}$ phase, increasing the avidity of protein for sphingolipid/cholesterol-enriched domains (Melkonian et al. 1999). Accordingly, a number of acylated proteins including heterotrimeric G-proteins $\alpha$-subunits, some Src family kinases, GAP-43 are resident in the lipid rafts (Arni et al. 1998, Melkonian et al. 1999, Papoucheva et al. 2004). It has been also shown that removal of the fatty acid modifications leads to the loss of the protein as- 
sociation with the lipid rafts and caveolae (Shaul et al. 1996, Shenoy-Scaria et al. 1994). It is, however, noteworthy that the described results were mainly obtained on peripheral membrane proteins and cannot be simply extended on integral membrane proteins. Importance of palmitoylation as a raft targeting signal for the latter remains controversial. For example, it has been shown that mutation of all palmitoylated cysteine residues on caveolin-1 does not affect its caveolae localization (Dietzen et al. 1995). On the other hand, reconstitution experiments have demonstrated that defined transmembrane peptides become excluded from $1_{\mathrm{o}}$ domains regardless of their acylation state (van Duyl et al. 2002). For the GPCRs, whose Cterminal intracellular domains are generally palmitoylated, the role of acylation as a targeting signal for the rafts/caveolae localization has not been investigated so far. Several members of GPCR superfamily have been shown to be highly enriched in lipid rafts and caveolae, whereas others are present only in small amounts or excluded from the lipid rafts (Chini and Parenti 2004).

In the present study we found that approximately $33 \%$ of the wild-type 5-HT1A receptor resides in the detergent-resistant membrane subdomains (DRMs). Cholesterol depletion results in solubilization of the 5-HT1A receptor, confirming association of the receptor with the cholesterol-enriched domains. DRM localization of the 5-HT1A was equally evident in different cell types (NIH $3 \mathrm{~T} 3$ and $\mathrm{CHO}$ ) suggesting that segregation of the receptor into lipid subdomains is intrinsic to the 5-HT1A itself. In contrast to the wild-type receptor, population of the acylation-deficient 5-HT1A receptor resided in TritonX-100 insoluble fractions was significantly reduced, suggesting an importance of receptor palmitoylation for the DRM trafficking.

Treatment of cells with non-ionic detergents at low temperature used in this study represents a classical approach for the DRM isolation. However, this method often produces controversial results and should not be expected to extract lipid rafts from cell membranes precisely (Simons and Vaz 2004). Therefore, we used copatching as an additional assay to analyze the membrane distribution of the 5-HT1A receptor. This assay is based on the observation that two membrane components sharing a preference for lipid rafts will coalesce to form tightly associated patches after treatment with specific cross-linking reagents, like antibodies or multimeric toxins (Verkade et al. 2000). Analysis of copatching data revealed that $30.3 \pm 4.1 \%$ of the 5 -HT1 A receptor was co-localized with the lipid raft ganglioside GM1. In contrast, the co-localization of the acylation-deficient mutant with the raft marker was drastically reduced. Thus, by using two independent methods we demonstrated that the significant fraction of the 5-HT1A receptor resides in lipid rafts in palmitoylation-dependent manner. Combined with our previous data on the signaling deficiency of non-palmitoylated 5-HT1A receptor, this finding suggests that the palmitoylation-dependent raft localization of receptor plays an essential role in the receptor-mediated signaling processes.

How can palmitoylation-mediated localization of the 5-HT1A receptor in rafts be involved 
in regulation of the receptor activity? One possible scenario is that the irreversible receptor palmitoylation will initiate the transient targeting of the receptor to lipid rafts. Such transient raft association may be further stabilized by the precoupling of the receptor with the G⿰ $\alpha_{i}$ protein (Emerit et al. 1990), which mainly resides in rafts (Oh and Schnitzer 2001). Activation of the receptor will result in dissociation of the receptor bound $\mathrm{G} \alpha_{\mathrm{i}}$-protein heterotrimeric complex thereby reducing the fraction of receptor interacting with G-protein (Janetopoulos et al. 2001). Such uncoupled receptors have been shown to possess increased mobility (Janetopoulos et al. 2001) and could therefore leave the lipid microdomains by the lateral diffusion. Outside of lipid rafts, the uncoupled 5-HT1 A receptors become "non-functional" in terms of efficient signalling and need to undergo another cycle of raft localization to initialize activation of the $\mathrm{G \alpha}_{\mathrm{i}}$-protein and downstream effectors upon stimulation. Several experimental observations argue for reliability of such model: (i) our data demonstrate that non-functional, acylation-deficient 5-HT1A mutant is excluded from DRMs, (ii) removal of cholesterol from hippocampal cells has been found to affect Go-protein coupling of the 5-HT1A receptor and to affect the specific agonist binding (Pucadyil et al. 2004) (iii) it has been shown that differently to other GPCRs, prolonged agonist stimulation of the 5-HT1A receptor does not result in considerable receptor internalization (Pucadyil et al. 2004, Riad et al. 2001).

Taken together, our data demonstrate that stable palmitoylation of the 5-HT1A receptor represents an important targeting signal responsible for localization of receptor in GM1-enriched membrane subdomains. More importantly, such palmitoylation-dependent rafts localization seems to play important role for efficient downstream signaling. 


\section{Summary}

We analyzed role of 5-HT1A and 5- $\mathrm{HT}_{4(\mathrm{a})}$ receptor palmitoylation in the receptor functions. In case of 5- $\mathrm{HT}_{4(\mathrm{a})}$ receptor we demonstrated that receptor palmitoylation affects phosphorylation. We showed that upon 5-HT stimulation, the 5- $\mathrm{HT}_{4(\mathrm{a})}$ receptor undergoes rapid $\left(\tau_{1 / 2}=2 \mathrm{~min}\right)$ and dose-dependent $\left(\mathrm{EC}_{50}=180 \mathrm{nM}\right)$ phosphorylation on serine residues by a staurosporine-insensitive receptor kinase. The acylation deficient (Cys328/29-Ser) mutant, which is constitutively active in the absence of ligand, exhibited enhanced receptor phosphorylation under both basal and agonist-stimulated conditions and was more effectively desensitized and internalized via GRK2/ $\beta$-arrestin pathway compared with the wild-type $5-\mathrm{HT}_{4(\mathrm{a})}$ receptor. G-protein activation, phosphorylation, desensitization and internalization of the other acylaiton deficient receptor mutants were affected differently. Analysis of dynamic interactio between receptor and $\beta$-arrestin 2 by BRET $^{2}$ assay demonstrated that wildtype and all palmitoylation deficient mutants show accelerated interaction with $\beta$-arrestin2 upon agonist stimulation. Acylation deficient mutants demonstrated a higher basal level of interaction with $\beta$-arrestin 2 than the wild-type, but a slower interaction kinetic $\left(\tau_{1 / 2}=12 \mathrm{sec}\right.$. for Cys328/29-S vs. 10 seconds for the wild-type) after stimulation with agonist. Co-expression of wild-type form of the GRK 2 promotes receptor- $\beta$-arrestin 2 interaction, while dominant negative mutant slightly reduce this affect, suggesting that the positive effect of GRK on receptor- $\beta$-arrestin 2 interaction is mediated both by enzymatic activity as well as by direct interaction of GRK2 with the receptor. These findings suggest that palmitoylation plays an important role in modulating 5- $\mathrm{HT}_{4(\mathrm{a})}$ receptor functions and that G-protein activation, phosphorylation, desensitization, and internalization of the receptor are regulated by this dynamic modification.

In the second part of the study we addressed the question on the molecular mechanisms by which receptor palmitoylation may regulate communication between receptors and $\mathrm{G \alpha}_{\mathrm{i}}$-proteins. In contrast to 5- $\mathrm{HT}_{4(\mathrm{a})}$ receptor, which undergoes dynamic pamitoylation, palmitoylation of 5-HT1A is an irreversible modification. Our data demonstrate that activation of the 5-HT1A receptor caused an activation of $\mathrm{G \alpha}_{\mathrm{i} 3}$ protein. In contrast, acylation-deficient 5-HT1A mutant failed to reproduce $\mathrm{G \alpha}_{\mathrm{i} 3}$ activation upon agonist stimulation. By using gradient centrifugation and co-patching assays, we also demonstrated that a significant fraction of the 5-HT1A receptor resides in lipid rafts, while the yield of the palmitoylation-deficient receptor in these membrane microdomains is considerably reduced. These data suggest that receptor palmitoylation serves as a targeting signal responsible for the retention of the 5-HT1A receptor in lipid rafts, and the raft localization of the 5-HT1A receptor appears to be involved in receptor-mediated signaling. 


\section{Acknowledgments}

First of all, I want to thank you my supervisor PD Dr. Evgeni Ponimaskin for his supervising, for giving me the opportunity to work in his lab.

I would like to express my appreciation to the members of my PhD Committee: Prof. Diethelm Richter and Prof. Harald Neumann, for their comments and suggestions during our meetings.

I am beholden to Dr. Ute Renner for her valuable suggestions, Fritz Kobe for the fruitful discussions, and of course to Gabi Klaehn for her excellent technical assistance.

I sincerely thank to my past and present colleagues, who helped me all these years: Dr. E. Papusheva, Dr. E. Kvachnina, Dr. Dietmar Hess, Tobias Schwarz, Dr. Jakub Wlodarczyk, Andrew Woehler, Dagmar Crzan.

I am gratefull to the Neuroscience Program Coordination Office, Prof. Dr. Michael Hörner and Sandra Drube for their help during my study.

Finaly, I would like to thank you my parents and grandmother for their huge support for all this five years.

At the end, I would like to admit my first scientific supervisor Acad., Prof. Ralf Tsoi, who introduced me to the wonderful world of science, and whose sudden passing away came as a true shock to all his students and colleagues. 


\section{References:}

Akgoz M, Azpiazu I, Kalyanaraman V, Gautam N (2002 May 31) Role of the G protein gamma subunit in beta gamma complex modulation of phospholipase Cbeta function. J Biol Chem 277(22): 19573-19578.

Albert PR, Lembo P, Storring JM, Charest A, Saucier C (1996 Jan) The 5-HT1A receptor: signaling, desensitization, and gene transcription. Neuropsychopharmacology 14(1): 19-25.

Alousi AA, Jasper JR, Insel PA, Motulsky HJ (1991 Jun) Stoichiometry of receptor-Gs-adenylate cyclase interactions. FASEB J 5(9): 2300-2303.

Angers S, Salahpour A, Bouvier M (2001 Apr 6) Biochemical and biophysical demonstration of GPCR oligomerization in mammalian cells. Life Sci 68(19-20): 2243-2250.

Angers S, Salahpour A, Joly E, Hilairet S, Chelsky D, et al. (2000 Mar 28) Detection of beta 2-adrenergic receptor dimerization in living cells using bioluminescence resonance energy transfer (BRET). Proc Natl Acad Sci U S A 97(7): 3684-3689.

Ansanay H, Sebben M, Bockaert J, Dumuis A (1992 Nov) Characterization of homologous 5-hydroxytryptamine4 receptor desensitization in colliculi neurons. Mol Pharmacol 42(5): 808-816.

Arni S, Keilbaugh SA, Ostermeyer AG, Brown DA (1998 Oct 23) Association of GAP43 with detergent-resistant membranes requires two palmitoylated cysteine residues. J Biol Chem 273(43): 28478-28485.

Avery J, Ellis DJ, Lang T, Holroyd P, Riedel D, et al. (2000 Jan 24) A cell-free system for regulated exocytosis in PC12 cells. J Cell Biol 148(2): 317-324.

Bargmann CI (1998 Dec 11) Neurobiology of the Caenorhabditis elegans genome. Science 282(5396): 2028-2033.

Barnes NM, Sharp T (1999 Aug) A review of central 5-HT receptors and their function. Neuropharmacology 38(8): 1083-1152.

Berg KA, Clarke WP (2001 Nov 15) Regulation of 5-HT(1A) and 5-HT(1B) receptor systems by phospholipid signaling cascades. Brain Res Bull 56(5): 471-477.

Blank JL, Ross AH, Exton JH (1991 Sep 25) Purification and characterization of two G-proteins that activate the beta 1 isozyme of phosphoinositide-specific phospholipase C. Identification as members of the Gq class. J Biol Chem 266(27): 18206-18216.

Bockaert J, Pin JP (1999 Apr 1) Molecular tinkering of G protein-coupled receptors: an evolutionary success. EMBO J 18(7): 1723-1729. 
Braun PE, Radin NS (1969 Nov) Interactions of lipids with a membrane structural protein from myelin. Biochemistry 8(11): 4310-4318.

Bunemann M, Hosey MM (1999 May 15) G-protein coupled receptor kinases as modulators of G-protein signalling. J Physiol 517 (Pt 1): 5-23.

Butkerait P, Zheng Y, Hallak H, Graham TE, Miller HA, et al. (1995 Aug 4) Expression of the human 5-hydroxytryptamine1 A receptor in Sf9 cells. Reconstitution of a coupled phenotype by co-expression of mammalian G protein subunits. J Biol Chem 270(31): 18691-18699.

Cassill JA, Whitney M, Joazeiro CA, Becker A, Zuker CS (1991 Dec 15) Isolation of Drosophila genes encoding G protein-coupled receptor kinases. Proc Natl Acad Sci U S A 88(24): 11067-11070.

Charest PG, Bouvier M (2003 Oct 17) Palmitoylation of the V2 vasopressin receptor carboxyl tail enhances beta-arrestin recruitment leading to efficient receptor endocytosis and ERK1/2 activation. J Biol Chem 278(42): 41541-41551.

Chen J, Shen C, Meller E (2002 Oct 4) 5-HT1A receptor-mediated regulation of mitogenactivated protein kinase phosphorylation in rat brain. Eur J Pharmacol 452(2): 155-162.

Chini B, Parenti M (2004 Apr) G-protein coupled receptors in lipid rafts and caveolae: how, when and why do they go there? J Mol Endocrinol 32(2): 325-338.

Cho S, Dawson PE, Dawson G (2000 Oct 15) Antisense palmitoyl protein thioesterase 1 (PPT1) treatment inhibits PPT1 activity and increases cell death in LA-N-5 neuroblastoma cells. J Neurosci Res 62(2): 234-240.

Chudakov DM, Lukyanov S, Lukyanov KA (2005 Dec) Fluorescent proteins as a toolkit for in vivo imaging. Trends Biotechnol 23(12): 605-613.

Claing A, Laporte SA (2005 Sep) Novel roles for arrestins in G protein-coupled receptor biology and drug discovery. Curr Opin Drug Discov Devel 8(5): 585-589.

Clapham DE, Neer EJ (1997) G protein beta gamma subunits. Annu Rev Pharmacol Toxicol 37: 167-203.

Collins LR, Minden A, Karin M, Brown JH (1996 Jul 19) Galpha12 stimulates c-Jun NH2-terminal kinase through the small G proteins Ras and Rac. J Biol Chem 271(29): 17349-17353.

Coso OA, Teramoto H, Simonds WF, Gutkind JS (1996 Feb 23) Signaling from G proteincoupled receptors to c-Jun kinase involves beta gamma subunits of heterotrimeric G proteins acting on a Ras and Rac1-dependent pathway. J Biol Chem 271(8): 3963-3966. 
Cowen DS, Sowers RS, Manning DR (1996 Sep 13) Activation of a mitogen-activated protein kinase (ERK2) by the 5-hydroxytryptamine1A receptor is sensitive not only to inhibitors of phosphatidylinositol 3-kinase, but to an inhibitor of phosphatidylcholine hydrolysis. J Biol Chem 271(37): 22297-22300.

Das AK, Kundu M, Chakrabarti P, Basu J (1992 Jul 27) Fatty acylation of a 55 kDa membrane protein of human erythrocytes. Biochim Biophys Acta 1108(2): 128-132.

Dawson LA, Hughes ZA, Starr KR, Storey JD, Bettelini L, et al. (2006 Jun) Characterisation of the selective 5-HT1B receptor antagonist SB-616234-A (1-[6-(cis-3,5-dimethylpiperazin-1-yl)-2,3-dihydro-5-methoxyindol-1-yl]-1- [2'-methyl-4'-(5-methyl-1,2,4-oxadiazol-3yl)biphenyl-4-yl]methanone hydrochloride): in vivo neurochemical and behavioural evidence of anxiolytic/antidepressant activity. Neuropharmacology 50(8): 975-983.

Degtyarev MY, Spiegel AM, Jones TL (1993 Nov 15) Increased palmitoylation of the Gs protein alpha subunit after activation by the beta-adrenergic receptor or cholera toxin. J Biol Chem 268(32): 23769-23772.

Delgado M, Caicoya AG, Greciano V, Benhamu B, Lopez-Rodriguez ML, et al. (2005 Mar 21) Anxiolytic-like effect of a serotonergic ligand with high affinity for 5-HT1A, 5-HT2A and 5-HT3 receptors. Eur J Pharmacol 511(1): 9-19.

Devreotes PN (1994 Feb) G protein-linked signaling pathways control the developmental program of Dictyostelium. Neuron 12(2): 235-241.

Dietzen DJ, Hastings WR, Lublin DM (1995 Mar 24) Caveolin is palmitoylated on multiple cysteine residues. Palmitoylation is not necessary for localization of caveolin to caveolae. J Biol Chem 270(12): 6838-6842.

Dohlman HG, Thorner J, Caron MG, Lefkowitz RJ (1991) Model systems for the study of seven-transmembrane-segment receptors. Annu Rev Biochem 60: 653-688.

Emerit MB, el Mestikawy S, Gozlan H, Rouot B, Hamon M (1990 Jan 1) Physical evidence of the coupling of solubilized 5-HT1A binding sites with G regulatory proteins. Biochem Pharmacol 39(1): 7-18.

Faure M, Voyno-Yasenetskaya TA, Bourne HR (1994 Mar 18) cAMP and beta gamma subunits of heterotrimeric $\mathrm{G}$ proteins stimulate the mitogen-activated protein kinase pathway in COS-7 cells. J Biol Chem 269(11): 7851-7854.

Fotiadis D, Jastrzebska B, Philippsen A, Muller DJ, Palczewski K, et al. (2006 Apr) Structure of the rhodopsin dimer: a working model for G-protein-coupled receptors. Curr Opin Struct Biol 16(2): 252-259. 
Freedman NJ, Ament AS, Oppermann M, Stoffel RH, Exum ST, et al. (1997 Jul 11) Phosphorylation and desensitization of human endothelin A and B receptors. Evidence for $\mathrm{G}$ protein-coupled receptor kinase specificity. J Biol Chem 272(28): 17734-17743.

Freshney RI (2000-04-02) Culture of Animal Cells: A Manual of Basic Technique, 4th Edition. Wiley-Liss.

Fricker AD, Rios C, Devi LA, Gomes I (2005 Aug 18) Serotonin receptor activation leads to neurite outgrowth and neuronal survival. Brain Res Mol Brain Res 138(2): 228-235.

Fukata M, Fukata Y, Adesnik H, Nicoll RA, Bredt DS (2004 Dec 16) Identification of PSD-95 palmitoylating enzymes. Neuron 44(6): 987-996.

Fukata Y, Iwanaga T, Fukata M (2006 Oct) Systematic screening for palmitoyl transferase activity of the DHHC protein family in mammalian cells. Methods 40(2): 177-182.

Gao Z, Ni Y, Szabo G, Linden J (1999 Sep 1) Palmitoylation of the recombinant human A1 adenosine receptor: enhanced proteolysis of palmitoylation-deficient mutant receptors. Biochem J 342 (Pt 2): 387-395.

Gales C, Rebois RV, Hogue M, Trieu P, Breit A, et al. (2005 Mar) Real-time monitoring of receptor and G-protein interactions in living cells. Nat Methods 2(3): 177-184.

Germain-Desprez D, Bazinet M, Bouvier M, Aubry M (2003 Jun 20) Oligomerization of transcriptional intermediary factor 1 regulators and interaction with ZNF74 nuclear matrix protein revealed by bioluminescence resonance energy transfer in living cells. J Biol Chem 278(25): 22367-22373.

Gether U (2000 Feb) Uncovering molecular mechanisms involved in activation of G protein-coupled receptors. Endocr Rev 21(1): 90-113.

Gilman AG (1987) G proteins: transducers of receptor-generated signals. Annu Rev Biochem 56: 615-649.

Gomes I, Filipovska J, Jordan BA, Devi LA (2002 Aug) Oligomerization of opioid receptors. Methods 27(4): 358-365.

Groarke DA, Drmota T, Bahia DS, Evans NA, Wilson S, et al. (2001 Feb) Analysis of the $\mathrm{C}$-terminal tail of the rat thyrotropin-releasing hormone receptor-1 in interactions and cointernalization with beta-arrestin 1-green fluorescent protein. Mol Pharmacol 59(2): 375-385.

Han M, Gurevich VV, Vishnivetskiy SA, Sigler PB, Schubert C (2001 Sep) Crystal structure of beta-arrestin at $1.9 \mathrm{~A}$ : possible mechanism of receptor binding and membrane Translocation. Structure 9(9): 869-880. 
Hanyaloglu AC, Seeber RM, Kohout TA, Lefkowitz RJ, Eidne KA (2002 Dec 27) Homoand hetero-oligomerization of thyrotropin-releasing hormone (TRH) receptor subtypes. Differential regulation of beta-arrestins 1 and 2. J Biol Chem 277(52): 50422-50430.

Harder T, Scheiffele P, Verkade P, Simons K (1998 May 18) Lipid domain structure of the plasma membrane revealed by patching of membrane components. J Cell Biol 141(4): 929-942.

Harhammer R, Gohla A, Schultz G (1996 Dec 16) Interaction of G protein Gbetagamma dimers with small GTP-binding proteins of the Rho family. FEBS Lett 399(3): 211-214.

Hawtin SR, Tobin AB, Patel S, Wheatley M (2001 Oct 12) Palmitoylation of the vasopres$\sin \mathrm{V} 1$ a receptor reveals different conformational requirements for signaling, agonist-induced receptor phosphorylation, and sequestration. J Biol Chem 276(41): 38139-38146.

Hebert TE, Moffett S, Morello JP, Loisel TP, Bichet DG, et al. (1996 Jul 5) A peptide derived from a beta2-adrenergic receptor transmembrane domain inhibits both receptor dimerization and activation. J Biol Chem 271(27): 16384-16392.

Herrick-Davis K, Grinde E, Mazurkiewicz JE (2004 Nov 9) Biochemical and biophysical characterization of serotonin 5-HT2C receptor homodimers on the plasma membrane of living cells. Biochemistry 43(44): 13963-13971.

Horn F, Weare J, Beukers MW, Horsch S, Bairoch A, et al. (1998 Jan 1) GPCRDB: an information system for G protein-coupled receptors. Nucleic Acids Res 26(1): 275-279.

Hur EM, Kim KT (2002 May) The stoichiometry of expression of protein components of the stimulatory adenylyl cyclase cascade and the regulation of information transfer. Cell Signal 14(5): 397-405.

Issafras H, Angers S, Bulenger S, Blanpain C, Parmentier M, et al. (2002 Sep 20) Constitutive agonist-independent CCR5 oligomerization and antibody-mediated clustering occurring at physiological levels of receptors. J Biol Chem 277(38): 34666-34673.

Iwami G, Kawabe J, Ebina T, Cannon PJ, Homcy CJ, et al. (1995 May 26) Regulation of adenylyl cyclase by protein kinase A. J Biol Chem 270(21): 12481-12484.

Janetopoulos C, Jin T, Devreotes P (2001 Mar 23) Receptor-mediated activation of heterotrimeric G-proteins in living cells. Science 291(5512): 2408-2411.

Kallal L, Benovic JL (2000 May) Using green fluorescent proteins to study G-protein-coupled receptor localization and trafficking. Trends Pharmacol Sci 21(5): 175-180.

Kennedy ME, Limbird LE (1994 Dec 16) Palmitoylation of the alpha 2A-adrenergic receptor. Analysis of the sequence requirements for and the dynamic properties of alpha $2 \mathrm{~A}-\mathrm{ad}-$ 
renergic receptor palmitoylation. J Biol Chem 269(50): 31915-31922.

Kong G, Penn R, Benovic JL (1994 May 6) A beta-adrenergic receptor kinase dominant negative mutant attenuates desensitization of the beta 2 -adrenergic receptor. $\mathrm{J}$ Biol Chem 269(18): 13084-13087.

Kraft K, Olbrich H, Majoul I, Mack M, Proudfoot A, et al. (2001 Sep 14) Characterization of sequence determinants within the carboxyl-terminal domain of chemokine receptor CCR5 that regulate signaling and receptor internalization. J Biol Chem 276(37): 34408-34418.

Kroeger KM, Hanyaloglu AC, Seeber RM, Miles LE, Eidne KA(2001 Apr 20) Constitutive and agonist-dependent homo-oligomerization of the thyrotropin-releasing hormone receptor. Detection in living cells using bioluminescence resonance energy transfer. J Biol Chem 276(16): 12736-12743.

Kroeze WK, Kristiansen K, Roth BL (2002 Jun) Molecular biology of serotonin receptors structure and function at the molecular level. Curr Top Med Chem 2(6): 507-528.

Kvachnina E, Liu G, Dityatev A, Renner U, Dumuis A, et al. (2005 Aug 24) 5-HT7 receptor is coupled to $\mathrm{G}$ alpha subunits of heterotrimeric G12-protein to regulate gene transcription and neuronal morphology. J Neurosci 25(34): 7821-7830.

Lanfumey L, Hamon M (2004 Feb) 5-HT1 receptors. Curr Drug Targets CNS Neurol Disord 3(1): 1-10.

Lang T, Bruns D, Wenzel D, Riedel D, Holroyd P, et al. (2001 May 1) SNAREs are concentrated in cholesterol-dependent clusters that define docking and fusion sites for exocytosis. EMBO J 20(9): 2202-2213.

Linder ME, Deschenes RJ (2003 Apr 22) New insights into the mechanisms of protein palmitoylation. Biochemistry 42(15): 4311-4320.

Linder ME, Kleuss C, Mumby SM (1995) Palmitoylation of G-protein alpha subunits. Methods Enzymol 250: 314-330.

Linder ME, Middleton P, Hepler JR, Taussig R, Gilman AG, et al. (1993 Apr 15) Lipid modifications of $\mathrm{G}$ proteins: alpha subunits are palmitoylated. Proc Natl Acad Sci U S A 90(8): 3675-3679.

Liu HY, Wenzel-Seifert K, Seifert R (2001 Jul) The olfactory G protein G(alphaolf) possesses a lower GDP-affinity and deactivates more rapidly than G(salphashort): consequences for receptor-coupling and adenylyl cyclase activation. J Neurochem 78(2): 325-338.

Liu YF, Ghahremani MH, Rasenick MM, Jakobs KH, Albert PR (1999 Jun 4) Stimulation of cAMP synthesis by Gi-coupled receptors upon ablation of distinct Galphai protein expres- 
sion. Gi subtype specificity of the 5-HT1A receptor. J Biol Chem 274(23): 16444-16450.

Logothetis DE, Kurachi Y, Galper J, Neer EJ, Clapham DE (1987 Jan 22-28) The beta gamma subunits of GTP-binding proteins activate the muscarinic $\mathrm{K}+$ channel in heart. Nature 325(6102): 321-326.

Lohse MJ, Benovic JL, Codina J, Caron MG, Lefkowitz RJ (1990 Jun 22) beta-Arrestin: a protein that regulates beta-adrenergic receptor function. Science 248(4962): 1547-1550.

Lundstrom K (2005 Nov) The future of G protein-coupled receptors as targets in drug discovery. IDrugs 8(11): 909-913.

Manzke T, Guenther U, Ponimaskin EG, Haller M, Dutschmann M, et al. (2003 Jul 11) 5HT4(a) receptors avert opioid-induced breathing depression without loss of analgesia. Science 301(5630): 226-229.

McCudden CR, Hains MD, Kimple RJ, Siderovski DP, Willard FS (2005 Mar) G-protein signaling: back to the future. Cell Mol Life Sci 62(5): 551-577.

Melkonian KA, Ostermeyer AG, Chen JZ, Roth MG, Brown DA (1999 Feb 5) Role of lipid modifications in targeting proteins to detergent-resistant membrane rafts. Many raft proteins are acylated, while few are prenylated. J Biol Chem 274(6): 3910-3917.

Mendez J, Kadia TM, Somayazula RK, El-Badawi KI, Cowen DS (1999 Jul) Differential coupling of serotonin 5-HT1A and 5-HT1B receptors to activation of ERK2 and inhibition of adenylyl cyclase in transfected CHO cells. J Neurochem 73(1): 162-168.

Mialet J, Fischmeister R, Lezoualc'h F (2003 Feb) Characterization of human 5-HT4(d) receptor desensitization in CHO cells. Br J Pharmacol 138(3): 445-452.

Milligan G (2004 Mar) Applications of bioluminescence- and fluorescence resonance energy transfer to drug discovery at G protein-coupled receptors. Eur J Pharm Sci 21(4): 397-405.

Moffett S, Brown DA, Linder ME (2000 Jan 21) Lipid-dependent targeting of G proteins into rafts. J Biol Chem 275(3): 2191-2198.

Moffett S, Mouillac B, Bonin H, Bouvier M (1993 Jan) Altered phosphorylation and desensitization patterns of a human beta 2-adrenergic receptor lacking the palmitoylated Cys341. EMBO J 12(1): 349-356.

Mumby SM (1997 Apr) Reversible palmitoylation of signaling proteins. Curr Opin Cell Biol 9(2): 148-154.

Mumby SM, Kleuss C, Gilman AG (1994 Mar 29) Receptor regulation of G-protein pal- 
mitoylation. Proc Natl Acad Sci U S A 91(7): 2800-2804.

Mumby SM, Muntz KH (1995 Feb) Receptor regulation of G protein palmitoylation. Biochem Soc Trans 23(1): 156-160.

Mundell SJ, Pula G, Carswell K, Roberts PJ, Kelly E (2003 Jan) Agonist-induced internalization of metabotropic glutamate receptor $1 \mathrm{~A}$ : structural determinants for protein kinase C- and G protein-coupled receptor kinase-mediated internalization. J Neurochem 84(2): 294-304.

Nakata H, Yoshioka K, Kamiya T, Tsuga H, Oyanagi K (2005) Functions of heteromeric association between adenosine and P2Y receptors. J Mol Neurosci 26(2-3): 233-238.

Nelson DL (2004 Feb) 5-HT5 receptors. Curr Drug Targets CNS Neurol Disord 3(1): 53-58.

Nurnberg B, Gudermann T, Schultz G (1995 Mar) Receptors and G proteins as primary components of transmembrane signal transduction. Part 2. G proteins: structure and function. J Mol Med 73(3): 123-132.

Oh P, Schnitzer JE (2001 Mar) Segregation of heterotrimeric G proteins in cell surface microdomains. G(q) binds caveolin to concentrate in caveolae, whereas G(i) and G(s) target lipid rafts by default. Mol Biol Cell 12(3): 685-698.

Onorato JJ, Palczewski K, Regan JW, Caron MG, Lefkowitz RJ, et al. (1991 May 28) Role of acidic amino acids in peptide substrates of the beta-adrenergic receptor kinase and rhodopsin kinase. Biochemistry 30(21): 5118-5125.

Palmer TM, Stiles GL (2000 Mar) Identification of threonine residues controlling the agonist-dependent phosphorylation and desensitization of the rat A(3) adenosine receptor. Mol Pharmacol 57(3): 539-545.

Papoucheva E, Dumuis A, Sebben M, Richter DW, Ponimaskin EG (2004 Jan 30) The 5hydroxytryptamine(1A) receptor is stably palmitoylated, and acylation is critical for communication of receptor with Gi protein. J Biol Chem 279(5): 3280-3291.

Pei G, Samama P, Lohse M, Wang M, Codina J, et al. (1994 Mar 29) A constitutively active mutant beta 2 -adrenergic receptor is constitutively desensitized and phosphorylated. Proc Natl Acad Sci U S A 91(7): 2699-2702.

Peitzsch RM, McLaughlin S (1993 Oct 5) Binding of acylated peptides and fatty acids to phospholipid vesicles: pertinence to myristoylated proteins. Biochemistry 32(39): 10436-10443.

Petaja-Repo UE, Hogue M, Leskela TT, Markkanen PM, Tuusa JT, et al. (2006 Jun 9) 
Distinct subcellular localization for constitutive and agonist-modulated palmitoylation of the human delta opioid receptor. J Biol Chem 281(23): 15780-15789.

Pfleger KD, Eidne KA (2003) New technologies: bioluminescence resonance energy transfer (BRET) for the detection of real time interactions involving G-protein coupled receptors. Pituitary 6(3): 141-151.

Plakidou-Dymock S, Dymock D, Hooley R (1998 Mar 12) A higher plant seven-transmembrane receptor that influences sensitivity to cytokinins. Curr Biol 8(6): 315-324.

Ponimaskin E, Dumuis A, Gaven F, Barthet G, Heine M, et al. (2005 May) Palmitoylation of the 5-hydroxytryptamine4a receptor regulates receptor phosphorylation, desensitization, and beta-arrestin-mediated endocytosis. Mol Pharmacol 67(5): 1434-1443.

Ponimaskin EG, Heine M, Joubert L, Sebben M, Bickmeyer U, et al. (2002 Jan 25b) The 5-hydroxytryptamine(4a) receptor is palmitoylated at two different sites, and acylation is critically involved in regulation of receptor constitutive activity. J Biol Chem 277(4): 2534-2546.

Ponimaskin EG, Profirovic J, Vaiskunaite R, Richter DW, Voyno-Yasenetskaya TA (2002 Jun 7a) 5-Hydroxytryptamine 4(a) receptor is coupled to the Galpha subunit of heterotrimeric G13 protein. J Biol Chem 277(23): 20812-20819.

Ponimaskin EG, Schmidt MF, Heine M, Bickmeyer U, Richter DW (2001 Feb 1) 5Hydroxytryptamine 4(a) receptor expressed in Sf9 cells is palmitoylated in an agonist-dependent manner. Biochem J 353(Pt 3): 627-634.

Pucadyil TJ, Kalipatnapu S, Harikumar KG, Rangaraj N, Karnik SS, et al. (2004 Dec 21) G-protein-dependent cell surface dynamics of the human serotonin1A receptor tagged to yellow fluorescent protein. Biochemistry 43(50): 15852-15862.

Qanbar R, Bouvier M (2003 Jan) Role of palmitoylation/depalmitoylation reactions in Gprotein-coupled receptor function. Pharmacol Ther 97(1): 1-33.

Rapport M, Green A, I P (1948 June 1) Partial purification of the vasoconstrictor in beef serum. J Biol Chem 174(2): 735-741.

Riad M, Watkins KC, Doucet E, Hamon M, Descarries L (2001 Nov 1) Agonist-induced internalization of serotonin-1a receptors in the dorsal raphe nucleus (autoreceptors) but not hippocampus (heteroreceptors). J Neurosci 21(21): 8378-8386.

Rodriguez-Frade JM, Vila-Coro AJ, de Ana AM, Albar JP, Martinez-A C, et al. (1999 Mar 30) The chemokine monocyte chemoattractant protein-1 induces functional responses through dimerization of its receptor CCR2. Proc Natl Acad Sci U S A 96(7): 3628-3633. 
Ross EM, Gilman AG (1977 Oct 25) Resolution of some components of adenylate cyclase necessary for catalytic activity. J Biol Chem 252(20): 6966-6969.

Sadeghi HM, Innamorati G, Dagarag M, Birnbaumer M (1997 Jul) Palmitoylation of the V2 vasopressin receptor. Mol Pharmacol 52(1): 21-29.

Schulein R, Liebenhoff U, Muller H, Birnbaumer M, Rosenthal W (1996 Jan 15) Properties of the human arginine vasopressin V2 receptor after site-directed mutagenesis of its putative palmitoylation site. Biochem J 313 (Pt 2): 611-616.

Shaul PW, Smart EJ, Robinson LJ, German Z, Yuhanna IS, et al. (1996 Mar 15) Acylation targets emdothelial nitric-oxide synthase to plasmalemmal caveolae. J Biol Chem 271(11): $6518-6522$.

Shenoy-Scaria AM, Dietzen DJ, Kwong J, Link DC, Lublin DM (1994 Jul) Cysteine3 of Src family protein tyrosine kinase determines palmitoylation and localization in caveolae. $\mathrm{J}$ Cell Biol 126(2): 353-363.

Simons K, Vaz WL (2004) Model systems, lipid rafts, and cell membranes. Annu Rev Biophys Biomol Struct 33: 269-295.

Smith GE, Ju G, Ericson BL, Moschera J, Lahm HW, et al. (1985 Dec) Modification and secretion of human interleukin 2 produced in insect cells by a baculovirus expression vector. Proc Natl Acad Sci U S A 82(24): 8404-8408.

Smith SK, Limbird LE (1982 Sep 10) Evidence that human platelet alpha-adrenergic receptors coupled to inhibition of adenylate cyclase are not associated with the subunit of adenylate cyclase ADP-ribosylated by cholera toxin. J Biol Chem 257(17): 10471-10478.

Soskic V, Nyakatura E, Roos M, Muller-Esterl W, Godovac-Zimmermann J (1999 Mar 26) Correlations in palmitoylation and multiple phosphorylation of rat bradykinin $\mathrm{B} 2$ receptor in Chinese hamster ovary cells. J Biol Chem 274(13): 8539-8545.

Spiegel S, Kassis S, Wilchek M, Fishman PH (1984 Nov) Direct visualization of redistribution and capping of fluorescent gangliosides on lymphocytes. J Cell Biol 99(5): 1575-1581.

Sterne-Marr R, Tesmer JJ, Day PW, Stracquatanio RP, Cilente JA, et al. (2003 Feb 21) $\mathrm{G}$ protein-coupled receptor Kinase $2 / \mathrm{G}$ alpha $\mathrm{q} / 11$ interaction. A novel surface on a regulator of $\mathrm{G}$ protein signaling homology domain for binding $\mathrm{G}$ alpha subunits. J Biol Chem 278(8): 6050-6058.

Sunahara RK, Taussig R (2002 Jun) Isoforms of mammalian adenylyl cyclase: multiplicities of signaling. Mol Interv 2(3): 168-184.

Sutherland EW, Rall TW (1958 Jun) Fractionation and characterization of a cyclic ad- 
enine ribonucleotide formed by tissue particles. J Biol Chem 232(2): 1077-1091.

Tang CM, Insel PA (2005 Dec) Genetic variation in G-protein-coupled receptors-consequences for G-protein-coupled receptors as drug targets. Expert Opin Ther Targets 9(6): $1247-1265$.

Tesmer JJ, Berman DM, Gilman AG, Sprang SR (1997 Apr 18) Structure of RGS4 bound to AlF4-activated G(i alpha1): stabilization of the transition state for GTP hydrolysis. Cell 89(2): 251-261.

Tesmer VM, Kawano T, Shankaranarayanan A, Kozasa T, Tesmer JJ (2005 Dec 9) Snapshot of activated $\mathrm{G}$ proteins at the membrane: the Galphaq-GRK2-Gbetagamma complex. Science 310(5754): 1686-1690.

Thompson MD, Burnham WM, Cole DE (2005) The G protein-coupled receptors: pharmacogenetics and disease. Crit Rev Clin Lab Sci 42(4): 311-392.

Twarog P, I P (1953 Oct) Serotonin content of some mammalian tissues and urine and a method for its determination. Am J Physiol 175(1): 157-161.

van Duyl BY, Rijkers DT, de Kruijff B, Killian JA (2002 Jul 17) Influence of hydrophobic mismatch and palmitoylation on the association of transmembrane alpha-helical peptides with detergent-resistant membranes. FEBS Lett 523(1-3): 79-84.

Varrault A, Journot L, Audigier Y, Bockaert J (1992 Jun) Transfection of human 5-hydroxytryptamine1A receptors in NIH-3T3 fibroblasts: effects of increasing receptor density on the coupling of 5-hydroxytryptamine1A receptors to adenylyl cyclase. Mol Pharmacol 41(6): 999-1007.

Vassilatis DK, Hohmann JG, Zeng H, Li F, Ranchalis JE, et al. (2003 Apr 15) The G protein-coupled receptor repertoires of human and mouse. Proc Natl Acad Sci U S A 100(8): 4903-4908.

Verkade P, Harder T, Lafont F, Simons K (2000 Feb 21) Induction of caveolae in the apical plasma membrane of Madin-Darby canine kidney cells. J Cell Biol 148(4): 727-739.

Voyno-Yasenetskaya TA, Faure MP, Ahn NG, Bourne HR (1996 Aug 30) Galpha12 and Galpha13 regulate extracellular signal-regulated kinase and c-Jun kinase pathways by different mechanisms in COS-7 cells. J Biol Chem 271(35): 21081-21087.

Wadsworth SJ, Gebauer G, van Rossum GD, Dhanasekaran N (1997 Nov 14) Ras-dependent signaling by the GTPase-deficient mutant of Galpha12. J Biol Chem 272(46): 28829-28832.

Wedegaertner PB, Wilson PT, Bourne HR (1995 Jan 13) Lipid modifications of trimeric 
G proteins. J Biol Chem 270(2): 503-506.

Yanai A, Huang K, Kang R, Singaraja RR, Arstikaitis P, et al. (2006 Jun) Palmitoylation of huntingtin by HIP14 is essential for its trafficking and function. Nat Neurosci 9(6): 824-831.

Zacharias DA, Violin JD, Newton AC, Tsien RY (2002 May 3) Partitioning of lipidmodified monomeric GFPs into membrane microdomains of live cells. Science 296(5569): 913-916. 


\section{Curriculum vitae}

Name: Konstantin Glebov

Date of birth: February 5, 1980

Citizenship: Russia

E-mail: konstantin.glebov@gmail.com

\section{EDUCATION:}

2002-2007 — International Master's/PhD/MD-PhD Neuroscience Program (Max Plank Society and George August University of Goettingen), Germany 2001 — Dept. of Pharmacology, Southwestern Medical Center at Dallas, University of Texas, USA

2000 - Cellular engineering and embryonic manipulation course, International Biotechnology Center, Moscow State University, Russia 1997-2001 — Department of Ecology and Genetics, Faculty of Biology, Tyumen State University, Russia 1987-1997 — Scholl №8, Tyumen, Russian Federation

\section{AWARDS:}

2002 - Award for the successes in scientific activity, Tyumen State University, Russia 2001 - Award for the active participation in $52^{\text {nd }}$ Scientific Conference in Tyumen State University, Russia $2000-2^{\text {nd }}$ prize on 51 Scientific Conference in Tyumen State University, Russia 2000 - Award for the special successes in educational and scientific activity, Tyumen State University, Russia

\section{GRANTS, SCHOLARSHIPS:}

2002-2006 Georg-Lichtenberg scholarship from the government of Lower Saxony, Germany

2001 — Laureate of regional grants competition. Topic: "Estimation of genetical stability in populations of Coregonidae in $\mathrm{Ob}$ - Irtish rivers basin, Russia 2000-2002 - special scholarship from the Council of the Biological faculty for the big achievements in scientific and social activities, Russia

\section{TEACHING, LECTURES, SEMINARS and GIVEN TALKS:}

2007 - talk, "Functional significance of post-translational modification of the serotonin receptors for signaling and localization" Dept. of Molecular Biology, Royal Colege of Surgeons, Dublin, Sweden. 
2007 — talk, "Functional significance of post-translational modification of the serotonin receptors for signaling and localization” Dept. of Molecular Biology, University of Umea, Sweden

2006 - talk, "Functional significance of post-translational modification of the serotonin receptors for intracellular signaling and localization" Institute des Neurosciences de Bordeaux, University of Bordeaux, France

2005 - talk, "Functional significance of post-translational modification of the serotonin receptors for intracellular signaling" Dept. of Pharmacology, Southwestern Medical Center at Dallas, University of Texas, USA

2003 - 1 week course "Modern molecular biological applications in science", one lecture and series of workshops, Faculty of Biology, Tyumen State University, Tyumen, Russia 2002-2007 — teaching for MSc students, molecular neuroscience; supervising short term research projects from MSc students

\section{PUBLICATIONS:}

1. "Palmitoylation of the 5-Hydroxytryptamine 4a Receptor Regulates Receptor Phosphorylation, Desensitization, and B-Arrestin-Mediated Endocytosis" E. Ponimaskin, A. Dumuis, F. Gaven, G. Barthet, M. Heine, K. Glebov, D. W. Richter, and M. Oppermann. Molecular Pharmacology Feb. 2, 2005

2. "Localization of the 5-HT1A receptor in lipid rafts is important for the receptor interaction with heterotrimeric $\mathrm{G} \alpha_{\mathrm{i}}$ protein and is dependent on receptor palmitoylation" $\mathrm{U}$. Renner†, K. Glebov†, et al. Submitted to Molecular Pharmacology, $\uparrow$ Authors contribute equally

3. "Analysis of the 5-HT $\mathrm{H}_{4(\mathrm{a})}$ receptor, its palmitoylation deficient mutants and $\beta$-arrestin interaction using the BRET ${ }^{2}$ assay", K. Glebov, E. Ponimaskin, manuscript in preparation

4. "Mechanisms underlying developmental regulation induced by adult-to-embryo chemical signaling: expression of serotonin receptors and signal transduction pathway”, E.E.Voronezhskaya†, K.I.Glebov†, M.Yu.Khabarova, E.G.Ponimaskin, L.P.Nezlin. Manuscript in preparation, $\uparrow$ Authors contribute equally 
